\title{
MECANISMOS «ALTERNATIVOS» FRENTE AL DESAHUCIO HIPOTECARIO DE LA VIVIENDA HABITUAL
}

\author{
Pilar Gutiémez Santiago \\ Profesora Titular de Derecho Civil (Acreditada \\ como Catedrátic a, 2009) \\ Universidad de León
}

\section{Resumen}

La irresponsable y descontrolada vorágine crediticia de los años de bonanza, unida a la crisis económica desatada en 2007-2008, ha desembocado en una avalancha de ejecuciones hipotecarias y en el desahucio de su vivienda habitual de miles de deudores incapaces de hacer frente a sus préstamos. Nuestro legislador, poco preocupado a su debido tiempo de articular mecanismos de prevención del sobreendeudamiento del consumidor de crédito (test de solvencia, información contractual y precontractual, transparencia bancaria), ha tratado luego -cuando el llamado "sinhogarismo" se había ya convertido en una auténtica lacra social- de parchear la situación con medidas ex post (suspensión de lanzamientos, quitas, dación en pago,...) que, en determinados casos, pueden enturbiar algunos postulados básicos del Derecho privado; todo ello sin perjuicio de que, activado el aparato del Estado Social, se hayan también puesto en marcha medidas paliativas de cariz público (prestaciones económicas de

- Palabras clave: Sobreendeudamiento del consumidor de crédito hipotecario; Ejecución hipotecaria; Lanzamiento de la vivienda habitual; "Sinhogarismo»; Sistemas extrajudiciales de resolución de conflictos; Mecanismos alternativos voluntarios o preceptivos; Arbitraje de consumo; Intermediación y mediación hipotecaria urgencia social, bolsas de alquiler social y hasta medidas expropiatorias -declaradas inconstitucionales- del uso temporal de viviendas desocupadas, propiedad de las entidades bancarias).

Con estas premisas, y ante la indiscutible y rabiosa "actualidad" de los sistemas alternativos de resolución de litigios en materia de consumo -moda auspiciada desde la propia Unión Europea-, en este trabajo se deja constancia del limitadísimo, por no decir nulo, papel del arbitraje de consumo en el campo de los desahucios hipotecarios y del relativo grado de éxito de la mediación hipotecaria. A tal fin, se examina cada una de ambas vías extrajudiciales en su proyección particular a los deudores hipotecarios atrapados por la coyuntura económica y en riesgo de perder su vivienda; estudio, cuyo enfoque técnicojurídico es acompañado de una óptica socio-económica de los costes y riesgos que juegan como incentivos o, por el contrario, y con mayor intensidad, como trabas fácticas a la viabilidad y eficiencia en la práctica de tales mecanismos alternativos. Junto a la normativa estatal en la materia, se atenderá también al Código de Consumo catalán que, llevando el fomento de esos sistemas hasta sus últimos extremos, ha instaurado una (dudosamente constitucional) presunción de sumisión al arbitraje de las entidades que otorgan créditos 
hipotecarios sobre la vivienda habitual y ha impuesto una mediación obligatoria -de discutible conveniencia- como trámite preceptivo previo al procedimiento judicial de ejecución hipotecaria.

Abstract

- Keywords: Consumer over-indebtedness mortgage; Mortgage foreclosure; Eviction from the habitual housing; "Homelessness"; Extrajudicial dispute resolution systems; Voluntary or mandatory alternative mechanisms; Consumer arbitration; Intermediation and mortgage mediation
Irresponsible and uncontrolled credit overfall in years of prosperity, followed by the economic crisis of 2007-2008, it has produced an avalanche of foreclosures and eviction from his habitual housing of thousands of debtors unable to pay their loans. Our legislator did not regulate timely mechanisms for the prevention of over-indebtedness consumer credit (solvency tests, pre-contractual and contractual information, bank transparency), and he has tried after -when the so-called "homelessness" has become a serious social problem- relieve the situation with ex post measures (suspension of eviction, debt reduction, payment with housing,...) which, in certain cases, may jeopardize some basic principles of private law; but also, based on the system of social state, have launched mitigation measures in this public order (economic benefits of social urgency, social rents and even expropriatory measures -declared unconstitutional- temporary use of housing unoccupied, property of banks).

From these premises, and at the obvious "fashion" of alternative dispute resolution systems in the field of consumer -fashion sponsored from the European Union-, this paper explains the very little, or none, paper consumer arbitration in the field of mortgage foreclosures and the relative success of the mortgage mediation. For that, I examined each of the two-judicial procedures in their particular application to mortgage debtors at risk of becoming homeless; study, whose technical and legal approach is accompanied by a socio-economic point of costs and risks playing as incentives or, on the contrary, and with greater intensity, as factual obstacles to the viability and efficiency in practical of such alternative mechanisms. In addition to state regulations, also study the Consumer Code of Cataluña that, with excessive promotion of these systems, he has established a (questionably constitutional) presumption of submission to arbitration of institutions providing mortgage credit housing and imposed a mandatory mediation -whose desirability is debatable- as a prerequisite for the judicial mortgage foreclosure process.

I. Crisis económica, ejecución hipotecaria y legislación «antidesahucios» - II. La «moda» de la resolución alternativa de los litigios de consumo: consideraciones introductorias sobre sus luces y sombras a propósito de su proyección particular a los desahucios hipotecarios - III. El (eventual) papel del arbitraje de consumo ante el desahucio de la vivienda habitual: su limitadísima virtualidad técnica y práctica - IV. La mediación hipotecaria como sistema de negociación asistida ante el riesgo de lanzamiento de la vivienda habitual 


\section{CRISIS ECONÓMICA, EJECUCIÓN HIPOTECARIA Y LEGISLACIÓN "ANTIDESAHUCIOS"}

La aguda y extraordinaria crisis económica que desde 2007-2008 ha asolado España ${ }^{1}$ ha traído consigo, entre otros reveses -vinculados a las cifras alarmantes de desempleo-,

Aunque no cabe aquí detenerse en los precedentes, avatares y causas desencadenantes de
la crisis en nuestro país, interesa recordar sucintamente que la misma obedeció a la
confluencia de múltiples factores, exógenos y endógenos, que se concretan, de modo
principal, en el estallido de la crisis norteamericana y su posterior globalización y
"contagio" a España, a lo que se unió la desaceleración económica provocada por el
pinchazo de la denominada burbuja inmobiliaria. Así, no puede obviarse, por un lado, la
falta de liquidez del sistema financiero causada por la irrupción en agosto de 2007 de la
crisis de las hipotecas «subprime» en Estados Unidos (vid. CALVO HORNERO, A., "La
crisis de las hipotecas subprime y el riesgo de credit crunch", Revista de Economía
Mundial, no.18, 2008, pp. 198 y ss.; NASARRE AZNAR, S., "La vivienda en propiedad
como causa y víctima de la crisis hipotecaria", Teoría y derecho, n'.16, 2014, pp. 13-18; y
"A legal perspective of the origin and the globalization of the current financial crisis and
the resulting reforms in Spain", en KENNA, P., Contemporary Housing Issues in a Globalized World, Ashgate Publishing, Londres, 2014, pp. 37 y ss.).

Por otro lado, tampoco cabe ignorar el deterioro interno de la economía española, la falta de financiación y el agotamiento del modelo económico de crecimiento -basado en la construcción («la gallina de los huevos de cemento», parafraseando a MARTÍN MATEO, R., La gallina de los huevos de cemento, Madrid, Civitas, 2007)-, al producirse una reducción drástica en los retornos de las inversiones y contenerse el crédito a la productividad económica, con la consecuente destrucción del tejido productivo y, por ende, el estremecedor aumento del paro y el descenso vertiginoso del consumo, todo lo cual creó un círculo vicioso de difícil salida. Este complejo y heterogéneo conglomerado de circunstancias llevó a situar en ratios sin parangón la deuda de las familias españolas respecto a las entidades financieras, correspondiendo el grueso de la misma a la cartera de créditos hipotecarios dirigidos a la adquisición de vivienda (vid. CEBALLOS PEÑA, D., "La mediación hipotecaria: un nuevo fenómeno de afrontamiento de conflictos en un entorno de crisis social", Revista de Mediación, nº.12, 2013, p. 23).

Sobre las razones del descalabro económico en España, sus turbulentos entresijos ideológicos, inmobiliarios y financieros y los estragos causados por la recesión se han escrito ríos de tinta a estas alturas: vid. entre otros estudios de interés, RECARTE GARCÍA-ANDRADE, A., "La crisis financiera internacional y el crack financiero español”, La Ilustración liberal, $n^{\circ} .37,2008$, pp. 27-73; GARCÍA MONTALVO, J., De la quimera inmobiliaria al colapso financiero, Barcelona, Bosch, 2008; TORTELLA, G./NÚÑEZ, C.E., Para comprender la crisis, Madrid, Gadir, 2009; BEL I QUERALT, G./ESTRUCH MANJÓN, A., "Crisis financiera y regulación. Tentación, pecado, penitencia y propósito de la enmienda", El Cronista, no.4, 2009, pp. 50-57; EMBID IRUJO, A., El Derecho de la crisis económica, Prensas Universitarias de Zaragoza, 2009; LAPARRA, M./PÉREZ ERANSUS, B. (Coords.), Crisis y fractura social en Europa. Causas y efectos en España, Colección Estudios Sociales, $n^{\circ} .35$, Obra Social de La Caixa, Barcelona, 2012; BERROCAL LANZAROT, A.I., "La vivienda hipotecada en la actual situación de crisis económica", en Garantías reales en escenarios de crisis: presente y prospectiva, Madrid, Marcial Pons, 2012, pp. 493-494; DÍEZ GARCÍA, H., Recargas hipotecarias e hipotecas recargables, Madrid, Reus, 2012, pp. 18-71; y ALCALÁ DÍAZ, $\mathrm{M}^{\mathrm{a}}$.Á., La protección del deudor hipotecario: Ley 1/2013, de 14 de mayo, de medidas para reforzar la protección a los deudores hipotecarios, reestructuración de deuda y alquiler social, Cizur Menor, Aranzadi, 2013, pp. 23-58. Particularmente ilustrativo del 
una avalancha de ejecuciones hipotecarias que han culminado con el lanzamiento de los deudores incapaces de hacer frente al pago de sus cuotas hipotecarias ${ }^{2}$. Ello ha conducido a que el derecho a una vivienda, consagrado en el art. 47 de la Constitución Española $^{3}$, se haya convertido para muchos ciudadanos en una quimera.

singular panorama jurídico e institucional español que, partiendo del actual carácter planetario de las relaciones económicas y financieras, precipitó la crisis en nuestro país es el libro de SOSA WAGNER, F. y FUERTES, M., Bancarrota del Estado y Europea como contexto, Madrid, Marcials Pons, 2011; autores que, con su habitual agudeza y rigor y su brillante pluma y amenidad narrativa, dan cuenta de los desaguisados de nuestros gobernantes que han puesto al Estado literalmente en almoneda, analizan los sectores en los que la situación de «bancarrota» se ha hecho más visible y lacerante (pp. 46 y ss.) y examinan las relaciones de esa ruina económica en su dimensión pública con las debilidades de la economía española en la esfera de la actividad privada destapadas por el hundimiento del negocio del ladrillo y el torbellino de la crisis financiera en los primeros pasos del siglo XXI (pp. 35 y ss.).

2 Según datos publicados en marzo de 2015 por el Instituto Nacional de Estadística (http://www.ine.es), el número de ejecuciones hipotecarias sobre viviendas habituales se situó en España en el año 2014 en 34.680, cifra un 7,4 \% superior a la de 2013. Aunque no existen en nuestro país datos claros sobre el número de desahucios producidos desde los albores de la crisis hasta la fecha -datos que varían en función de su procedencia de unos u otros organismos (Banco de España, Colegio de Registradores, Consejo General del Poder Judicial,...)-, las cifras que se barajan son, en todo caso, escalofriantes. En concreto, las estadísticas ofrecidas por el Consejo General del Poder Judicial revelan que, siquiera hasta 2015 -en que, como luego se dirá, comienza a atisbarse una ligera mejoría-, se ha asistido a un incremento progresivo (con muy leves vaivenes) de las ejecuciones hipotecarias: 25.943 en $2007,58.686$ en 2008, 93.319 en $2009,93.336$ en 2010, 77.854 en 2011, 91.622 en 2012 y 82.680 en 2013 (http://www.poderjudicial.es). Aunque en ese año 2013 se experimentó un descenso, los datos del primer trimestre de 2014 mostraron nuevamente un repunte significativo al producirse un aumento de un 14 $\%$ respecto del mismo trimestre del año anterior. Sin embargo, no en todas las ejecuciones hipotecarias se produce el lanzamiento ni todas son de primera vivienda. En 2012, por ejemplo, el número total de desahucios se elevó a 43.858 según el CGPJ, 44.745 según el Banco de España y 38.976 de acuerdo con los datos del Colegio de Registradores; pero sin llegarse a especificar con exactitud cuántos fueron concretamente desahucios de la vivienda habitual.

Un completo repaso estadístico en materia de ejecuciones y lanzamientos hipotecarios puede verse en RODRÍGUEZ LÓPEZ, J., "Ejecuciones hipotecarias. Un año de la Ley 1/2013", Revista de Derecho Civil [en adelante RDCiv.], no.3, 2014, pp. 106-110. Sobre la problemática ligada a la antes apuntada imprecisión y falta de coincidencia entre unas y otras estadísticas, vid. "Una aproximación a la conciliación de los datos sobre ejecuciones hipotecarias y desahucios", en Boletín Información Estadística, nº.35, junio 2013, CGPJ; y SÁNCHEZ RUIZ DE VALDIVIA, I., "Introducción. Alternativas ante el drama social y el problema legal que plantean los desahucios y las ejecuciones hipotecarias en los consumidores", en Desahucios y ejecuciones hipotecarias (un drama social y un problema legal), Valencia, Tirant lo Blanch, 2014, pp. 40-46.

3 En el ámbito internacional, el derecho a la vivienda viene recogido en el art. 25 de la Declaración Universal de Derechos Humanos y en el art. 11 del Pacto Internacional de Derechos Económicos, Sociales y Culturales, como parte del derecho a un nivel de vida adecuado. En cuanto a su reconocimiento en el seno de la Carta europea de Derechos Fundamentales, la Sentencia del Tribunal de Justicia de la Unión Europea de 10 de septiembre de 2014 (Asunto C-34/13, Caso Kušionová [JUR 2014\224808]) ha afirmado 
Ante ese angustioso drama personal (suicidios incluidos ${ }^{4}$ ) y el serio problema social que implica, el legislador español ha ido articulando a lo largo de estos años toda una serie de medidas, de muy distinto calado y naturaleza, destinadas a mitigar o aliviar la situación de los deudores hipotecarios en esa coyuntura.

\section{Remedios ex post del Derecho privado vs. mecanismos preventivos del sobreendeudamiento del consumidor de crédito}

En el plano del Derecho Privado - principalmente a raíz del Real Decreto-Ley $6 / 2012^{5}$, de la Ley $1 / 2013^{6}$ (la comúnmente llamada Ley Antidesahucios ${ }^{7}$ ) y de sus ulteriores reformas (entre ellas, la operada por la Ley $25 / 2015^{8}$ ) - se han previsto, como medidas estelares, y aun sin ánimo de exhaustividad, moratorias o suspensión de los lanzamientos de la vivienda ${ }^{9}$ ante determinadas condiciones económicas

textualmente que "el derecho a la vivienda es un derecho fundamental garantizado por el artículo 7 de la Carta, que el tribunal remitente debe tomar en consideración al aplicar la Directiva 93/13, de 5 de abril", pues en el caso enjuiciado se discutía una cláusula contractual que permitía la ejecución extrajudicial de la garantía hipotecaria sin que el juez tuviese la oportunidad de entrar a valorar su carácter abusivo. Dado que el proceso finalizaba con la ejecución y la pérdida de la vivienda por parte del consumidor, este hecho afectaba -concluyó la Sentencia- al respeto de su vida privada y familiar (art. 7 de la Carta de Derechos Fundamentales), con lo que, de este modo, el Tribunal de Justicia europeo vino así a incluir el derecho a la vivienda dentro del contenido de aquél.

4 Sostiene al respecto CARRASCO PERERA, Á., "Hipotecas sin desahucios", en Desahucios y ejecuciones hipotecarias (un drama social y un problema legal), Valencia, Tirant lo Blanch, 2014, p. 105, al hilo del art. 1 del Real Decreto-Ley 27/2012 de Medidas Urgentes para reforzar la Protección a los Deudores Hipotecarios, que "esta norma no fue propiamente una reacción legislativa a los desahucios, sino un modo de hacer algo ante el impacto mediático que estaban causando los suicidios de los desahuciados".

5 RD-Ley 6/2012, de 9 de marzo, de Medidas Urgentes de Protección de Deudores Hipotecarios sin Recursos.

6 Ley 1/2013, de 14 de mayo, de Medidas para reforzar la Protección a los Deudores Hipotecarios, Reestructuración de Deuda y Alquiler Social.

7 Crítico con esta "denominación" se muestra NÚÑEZ IGLESIAS, Á., "La suspensión de los lanzamientos en la ejecución hipotecaria", $R D C i v ., \mathrm{n}^{\circ} .1,2014, \mathrm{p} .70$, quien señala al respecto que "la mentada ley ha sido denominada «Antidesahucios», siendo así que el desahucio es justamente un procedimiento para promover la terminación del arrendamiento, generalmente por falta de pago. Aunque lo de «antidesahucios» no es sólo un alias vulgar de la ley, sino una «idea» asumida por el propio legislador que, confundido y arrastrado por la opinión pública del momento, ha denominado, como ella, «desahucio» al lanzamiento". Vid. en igual sentido SÁNCHEZ HERNÁNDEZ, C., "Garantía hipotecaria, mercado y crisis económica: bases para su reformulación”, Revista de Derecho Patrimonial [en adelante RDPatr.], nº.35, 2014, n. 36.

Sin perjuicio de las precedentes observaciones críticas y de que el vocablo desahucio debiera reservarse, en rigor, para el ámbito arrendaticio, advierto que en el presente estudio, referido a la ejecución hipotecaria, emplearé de forma indistinta los términos lanzamiento y desahucio.

8 Ley 25/2015, de 28 de julio, de Mecanismo de segunda oportunidad, reducción de la carga financiera y otras medidas de orden social.

9 Recuérdese que la suspensión de los lanzamientos -moratoria ope legis duramente criticada por CARRASCO PERERA, Á., "La corte de los milagros o la suspensión de lanzamientos hipotecarios", Actualidad Jurídica Aranzadi [en adelante AJA], nº.854, 2012, 
(objetivas y subjetivas -de especial vulnerabilidad o riesgo de exclusión social-) ${ }^{10}$, planes de reestructuración de deudas hipotecarias ${ }^{11}$, la posibilidad de quitas en el capital pendiente de amortización ${ }^{12}$, o la dación en pago de la vivienda habitual ${ }^{13}$

p. 2, pero bendecida por el TC con la inadmisión de las cuestiones de inconstitucionalidad promovidas contra la misma (Autos TC de 9 septiembre 2014 [RTC 2014\221] y 27 mayo 2014 [RTC 2014\152])- fue originariamente prevista por un plazo de dos años (RD-Ley 6/2012 y art. 1 Ley 1/2013; vid. al respecto, CORDERO LOBATO, E., "La paralización de desahucios hipotecarios", Revista CESCO, $\mathrm{n}^{\circ} .4$, 2012, pp. 207-210; BERCOVITZ RODRÍGUEZ-CANO, R., "El eco de la campanada", Aranzadi Civil-Mercantil [en adelante $\left.A C-M], \mathrm{n}^{\circ} .9,2013\right)$.

Sin embargo, a fin de reforzar la protección de los deudores hipotecarios, aquel primigenio plazo fue prorrogado hasta cuatro años por la Ley 25/2015 (art. 3); ley que asimismo amplió el elenco de colectivos considerados especialmente vulnerables y, eventualmente, beneficiarios de la suspensión. Vid. sobre el tema, al hilo del RD-Ley 1/2015, ZURITA MARTÍN, I., "Reflexiones sobre la ampliación del umbral de exclusión y el ámbito de aplicación del Código de Buenas Prácticas por medio del Real Decreto-Ley $1 / 2015$, de 27 de febrero, de mecanismo de segunda oportunidad, reducción de carga financiera y otras medidas de orden social", La Ley, nº $.8520,2015$.

10 Aunque muchos deudores hipotecarios se han beneficiado de dicha moratoria (Autos AAPP Girona 6 mayo 2015 [JUR 2015\165685] y Cádiz 30 junio 2014 [JUR $2015 \backslash 127662]$ ), también son numerosas las resoluciones judiciales que, dada la amalgama de rigurosos requisitos exigidos legalmente, deniegan la suspensión del lanzamiento de la vivienda habitual por no encontrarse el deudor dentro de alguno de los supuestos de especial vulnerabilidad previstos por el art. 1 de la Ley 1/2013 (SS. AAPP Barcelona 14 noviembre 2014 [AC 2014\2307], Girona 22 abril 2015 [JUR 2015\165845] y Baleares 22 julio 2015 [AC 2015\1364]), habiéndose asimismo inadmitido recurso de amparo por tal motivo (Auto TC de 5 mayo 2014 [RTC 2014\129]).

11 El "Código de Buenas Prácticas para la reestructuración viable de las deudas con garantía hipotecaria sobre la vivienda habitual" [en adelante, Código de Buenas Prácticas] -recogido en el Anexo del RD-Ley 6/2012, al que dio nueva redacción la Ley 1/2013 y reformado también por la Ley 25/2015- contempla en su aptdo. 1 una serie de "Medidas previas a la ejecución hipotecaria" encaminadas a establecer un plan viable (a medio y largo plazo) de reestructuración de la deuda: sobresalen entre dichas medidas -completamente razonables y que el deudor podrá "solicitar y obtener", siempre que en la ejecución iniciada no se haya llegado al anuncio de la subasta- el otorgamiento de un plazo de carencia (de cinco años) en la amortización de capital, la reducción del tipo de interés durante dicho lapso temporal, una ampliación del plazo de amortización (hasta un total de cuarenta años a contar desde la concesión del préstamo) o la reunificación del conjunto de deudas contraídas por el deudor.

12 El Código de Buenas Prácticas contempla la quita como una "Medida Complementaria" (aptdo. 2), cuya solicitud por el deudor hipotecario (admisible aunque ya se haya anunciado la subasta) procede principalmente cuando es inviable un plan de reestructuración de deudas; solicitud o propuesta por parte del deudor de reducción de su deuda que la entidad acreedora puede aceptar o rechazar.

13 A modo de paréntesis, interesa advertir que, como presupuesto objetivo para la aplicabilidad del Código de Buenas Prácticas y de las referidas medidas previstas en el mismo y en la Ley 1/2013 -cuyo supuesto de hecho se circunscribe a los créditos o préstamos garantizados con hipoteca sobre la "vivienda habitual", con exclusión de otros inmuebles-, el art. 3 de la citada Ley 1/2013 modificó el art. 21 de la Ley Hipotecaria añadiéndole un nuevo apartado a tenor del cual "en las escrituras de préstamo hipotecario sobre vivienda deberá constar el carácter, habitual o no, que pretenda atribuirse a la 
-en términos bastante restrictivos y con tan solo relativo grado de éxito en la práctica $^{14}$.

Ante la urgencia, magnitud y crudeza de la situación creada por el azote de la crisis, no cabe duda de las loables intenciones de tales medidas ex post pues, aunque opino que hay que ser rigurosos y cerrar el paso sin contemplaciones al que podríamos llamar el «deudor profesional» ${ }^{15}$, es innegable que centenares de miles de deudores de buena fe se vieron atrapados por la vorágine crediticia y suscribieron préstamos hipotecarios como consecuencia de una oferta masiva, descontrolada, poco responsable y escasamente transparente ${ }^{16}$-según reconoce abiertamente el Dictamen del Comité Económico y Social Europeo de 29 de abril de $2014^{17}-$.

vivienda que se hipoteque. Se presumirá, salvo prueba en contrario, que en el momento de la ejecución judicial del inmueble es vivienda habitual si así se hiciera constar en la escritura de constitución".

Sobre el concepto de vivienda habitual que toman como eje central de su ámbito objetivo de aplicación la Ley 1/2013 (art. 1.1) y el RD-Ley 6/2012 (arts. 2.2 y 3.1), vid. MARTÍNEZ DE SANTOS, A., Sobre la ejecución hipotecaria inmobiliaria, ¿Puede evitarse la ruina del ejecutado?, Foro Jurídico, Valencia, 2013, pp. 88 y ss.; y de forma muy pormenorizada, LÓPEZ AZCONA, A., "El ámbito de aplicación de las medidas de protección de los deudores hipotecarios y sus (restrictivos) criterios delimitadores", Revista General de Legislación y Jurisprudencia [en adelante RGLJ], nº.1, 2015, pp. 6568.

14 La regulación de esta polémica figura de la dación en pago "forzosa" (de aceptación obligatoria por parte de la entidad crediticia) se contiene, como "Medida sustitutiva de la ejecución hipotecaria", en el aptdo. 3 del Código de Buenas Prácticas, conforme al cual "la dación en pago supondrá la cancelación total de la deuda garantizada con hipoteca y de las responsabilidades personales del deudor y de terceros frente a la entidad por razón de la misma deuda".

Sin embargo, prevista como último recurso o remedio subsidiario ante una fallida reestructuración de la deuda y la no aceptación de la quita por la entidad acreedora, y ante los exigentes requisitos que la dación en pago reclama, su aplicación se restringe únicamente a un exiguo segmento de deudores hipotecarios -en situación de extrema marginalidad y penuria económica-. Vid. al respecto, p.ej. DE LA FUENTE NÚÑEZ DE CASTRO, Ma .S., "La dación en pago: ¿una solución eficaz a la situación socio económica del deudor inmobiliario?", Revista CESCO, nº.4, 2012.

15 Vid. VIGUER SOLER, P.L., "Análisis crítico del RDL 1/2015 sobre «segunda oportunidad»: expectativas, luces y sombras", La Ley, nº.8592, 2015.

16 Según afirma en tal sentido ALONSO PÉREZ, Ma.T., "El Código de Buenas Prácticas de reestructuración viable de las deudas con garantía hipotecaria sobre la vivienda habitual (Naturaleza jurídica y su análisis como supuesto específico de sobreendeudamiento de particulares)", RDCiv., $\mathrm{n}^{\mathrm{o}} .2,2015$, p. 63, entre los orígenes de la comprometida situación por la que atraviesan muchos deudores hipotecarios "debe atenderse a que las entidades acreedoras han tenido cierto grado de responsabilidad porque han observado un comportamiento negligente a la hora de conceder los préstamos, otorgándolos a personas de dudosa solvencia o aceptando como garantía bienes de escaso valor". También BLANCO GARCÍA, A.I., "La intermediación hipotecaria: la mejor opción contra ejecución hipotecaria", Revista Internacional de Estudios de Derecho Procesal y Arbitraje [en adelante RIEDPA], $\mathrm{n}^{\circ} .2,2015$, pp. 4-6, 8 y 10 hace hincapié en "el abuso de poder" y las "erráticas políticas de actuación y comercialización que han desarrollado las entidades de crédito" como principal causa de la catastrófica situación económica de 
los deudores hipotecarios tras la crisis, resaltando el perjuicio sufrido por estos como consecuencia de las "infracciones y vulneraciones de la normativa sobre transparencia y protección del consumidor" por parte de dichas entidades. En la misma línea se pronuncia VALL RIUS, A., "La intermediación en problemáticas hipotecarias", Revista Digital $M M, \mathrm{n}^{\circ} .2,2012$, p. 16 que, ante la dimensión que ha cobrado "el drama humano de dejar en la calle a familias enteras" como consecuencia de los lanzamientos hipotecarios, afirma que "los Bancos no pueden desentenderse totalmente de su responsabilidad en estas situaciones, ya que muchas veces ellos mismos estimularon la contratación de estos créditos hipotecarios con la finalidad de engrosar su cartera de créditos hipotecarios aunque fuese a base de activos tóxicos incobrables y de impulsar la asunción de obligaciones crediticias, que ya de entrada eran claramente desmesuradas y de difícil cumplimiento". Vid. igualmente LÓPEZ AZCONA, A., "El ámbito de aplicación de las medidas de protección de los deudores hipotecarios...", RGLJ, $\mathrm{n}^{\mathrm{o}} .1$, 2015, p. 41; ZUNZUNEGUI, F., "Sobreendeudamiento y prácticas hipotecarias de las entidades bancarias", Revista de Derecho Bancario y Bursátil [en adelante RDBB], $\mathrm{n}^{\circ} .129,2013$, p. 39; ROY PÉREZ, C., "La protección del consumidor en la contratación de productos y servicios bancarios: el crédito hipotecario", en Garantías reales en escenarios de crisis: presente y prospectiva, Madrid, Marcial Pons, 2012, pp. 459-460; VALIÑO, V., "Ejecuciones hipotecarias y derecho a la vivienda: estrategias jurídicas frente a la insolvencia familiar", Observatorio DESC, septiembre 2009 -quien afirma que estas actuaciones, consentidas por los poderes públicos, "fueron el producto de una relación simbiótica entre notarios, tasadores, entidades financieras e inmobiliarias y contienen claros indicios de fraude y estafa generalizada"-; y con detalle sobre las malas prácticas bancarias que estuvieron detrás de la concesión "alegre", impulsiva y a discreción de muchos créditos hipotecarios durante el boom inmobiliario, vid. NASARRE AZNAR, S., "Malas prácticas bancarias en la actividad hipotecaria", Revista Crítica de Derecho Inmobiliario [en adelante RCDI], $\mathrm{n}^{\circ} .727,2011$, pp. 2673 y ss.

Con todo, son no pocos los autores para los que no cabe considerar al Banco como el único «culpable», "como el malo de la película, y al cliente como a un disminuido mental al que hay que proteger de sí mismo": en estos términos se pronuncia LACRUZ MANTECÓN, M.L., "La moderna dación en pago", RDCiv., $\mathrm{n}^{\circ} .3$, 2014, p. 99, quien -bajo la gráfica rúbrica de «Hacia una sociedad irresponsable»- matiza la común imputación en exclusiva a los bancos de una política agresiva de concesión de créditos hipotecarios y enjuicia duramente ciertas aseveraciones del Informe del Defensor del Pueblo «Crisis económica y deudores hipotecarios: actuaciones y propuestas del Defensor del Pueblo» (entregado a las Cortes Generales el 25 de enero de 2012) en el que puede leerse que "si el deudor firmó un contrato de préstamo hipotecario fue no solamente por el ejercicio de una voluntad de endeudarse, sino porque el mercado inmobiliario y las condiciones de acceso a los préstamos eran las más laxas de toda la historia. Tipos de interés reducidos, alargamiento de la vida de los préstamos, concesión del total del valor de tasación en préstamo,..."; palabras de las que se deriva -sostiene LACRUZ- que, paradójicamente, "se está reprochando a los bancos el haber ofrecido dinero en buenas condiciones". Vid. también en un tono sumamente beligerante, CARRASCO PERERA, Á., "La corte de los milagros...", AJA, no ${ }^{\circ} 854,2012$. Aunque más moderadamente, y refiriéndose en particular a la tasación del inmueble a efectos de la concesión de un préstamo hipotecario, escribe al respecto SERRANO GARCÍA, I., "Soluciones legales en materia de desahucios en España", Revista Jurídica del Notariado [en adelante RJNot.], $\mathrm{n}^{\mathrm{o}} .86-87,2013$, pp. 101 y 110 que es cierto que durante mucho tiempo -sobre todo en los años de bonanza económica anteriores a la crisis- tal tasación era realizada por entidades que pertenecían al mismo grupo empresarial que las propias entidades de crédito que concedían el préstamo y que dichas entidades tasaban el inmueble con muy poco rigor, 
Así, y en otro orden de cosas, ha de ser bienvenida, por ejemplo, la posibilidad de rescate anticipado o disponibilidad de los planes de pensiones de aquellos titulares de los mismos incursos en un procedimiento de ejecución hipotecaria sobre la vivienda habitual $^{18}$. Y particularmente bienintencionadas son, en principio ${ }^{19}$, algunas de las medidas introducidas, vía reforma de la Ley Hipotecaria y de la Ley de Enjuiciamiento $\mathrm{Civil}^{20}$, a resultas del Derecho europeo ${ }^{21}$ y como reacción a los

haciendo subir y sobredimensionando su valoración cuando convenía. Sin embargo -añade el autor-, tampoco cabe ocultar que "muchos de los que ahora denuncian a los Bancos como los causantes de la crisis, solicitaron que se aumentara el valor de tasación para poder obtener un préstamo que les consintiera no sólo adquirir la vivienda hipotecada, sino también los muebles, e incluso el coche que pensaban comprar.... No quiero decir con ello - puntualiza- que los Bancos estén exentos de culpa, pero la culpa en muchos casos, está repartida entre Bancos y clientes. Hay que partir de la base de que en esta materia no hay nadie inocente". Vid. en la misma línea, BERROCAL, A.I., "La vivienda hipotecada en la actual situación...", en Garantías reales en escenarios de crisis..., 2012, p. 494; y SÁNCHEZ HERNÁNDEZ, C., "Garantía hipotecaria, mercado y crisis...", RDPatr., $\mathrm{n}^{\mathrm{o}} .35,2014$, quien sostiene que "la situación actual de sobreendeudamiento hipotecario es debida a una corresponsabilidad entre la actuación de las entidades de crédito y de los deudores hipotecarios": "las entidades han facilitado de forma imprudente el crédito", pero "tampoco cabe olvidar la cuota de responsabilidad imputable al deudor, que lo ha aceptado arriesgadamente".

17 Dictamen del CESE, relativo a la "Protección del consumidor y el adecuado tratamiento del sobreendeudamiento para evitar la exclusión social" (DOUE 12 septiembre 2014).

También se refiere a la «irresponsabilidad» en la concesión de préstamos y a los problemas que ello ha generado en el mercado hipotecario la Directiva 2014/17/UE sobre contratos de crédito celebrados con los consumidores para bienes inmuebles de uso residencial y por la que se modifican las Directivas 2008/48/CE y 2013/36/UE y el Reglamento 1093/2010 (vid. Considerandos $3^{\circ}$ y $4^{\circ}$ ).

18 A tal efecto, la Ley 1/2013 y, ulteriormente de nuevo, la Ley 25/2015 (Disposición Final $1^{\text {a }}$ ) reformaron el Texto Refundido de la Ley de Regulación de los Planes y Fondos de Pensiones, aprobado por Real Decreto Legislativo 1/2002, de 29 de noviembre (Disposición Adicional $7^{\mathrm{a}}$ ).

19 Dicho sea esto, sin perjuicio de que puedan detectarse algunas deficiencias técnicas en estas nuevas medidas y de que quepa considerar que las reformas que introducen en el procedimiento de ejecución hipotecaria no son satisfactorias ni constituyen la mejor solución (SERRANO, I., "Soluciones legales en materia de desahucios...", RJNot., no.8687,2013 , pp. 151-164, en especial pp. 157 y 160) o se entienda que simplemente vinieron a "maquillar" el sistema de ejecución hipotecaria (DÍEZ GARCÍA, H., "Igualdad de armas y tutela judicial efectiva en el art. 695.4 LEC tras el Real Decreto-Ley 11/2014, de 5 de septiembre: crónica de una reforma legislativa anunciada", Derecho Privado y Constitución [en adelante $D P y C$ ] $, \mathrm{n}^{\circ} .28,2014$, p. 211) y que son a todas luces insuficientes (ACHÓN BRUÑEN, $M^{\mathrm{a}}$.J., "Modificaciones del proceso de ejecución por la Ley de medidas para reforzar la protección a los deudores hipotecarios, reestructuración de deuda y alquiler social: deficiencias y problemas prácticos", La Ley, nº.8087, 2013) o incluso "de mínimos" (como críticamente apuntan FERNÁNDEZ-SANCHO TAHOCES, A.S., "Derecho a la vivienda y ejecución hipotecaria: valoración de las recientes reformas legales”, La Ley, no.8529, 2015; y PÉREZ HEREZA, J., “¿Una Ley definitiva para la protección del deudor hipotecario?”, El Notario, n' $.49,2013$, p. 4).

20 Vid. concretamente las modificaciones que, con el fin de realizar mejoras en el mercado hipotecario, introdujo la Ley 1/2013 (Capítulo II, art. 3) en la Ley Hipotecaria (arts. 21, 129 y, en especial, art. 114), así como las reformas efectuadas por dicha Ley de 2013 
reiterados varapalos que desde el Tribunal de Luxemburgo $^{22}$ se han venido propinando a nuestra legislación hipotecaria ${ }^{23}$; de modo especial, la posibilidad de

(Capítulo III, art. 7) en diversos aspectos de la regulación del procedimiento de ejecución hipotecaria por la LEC 1/2000 (arts. 552, 557, 561, 575 y 579, arts. 647, 654, 668, 670, $671,682,691,693$ y, especialmente, art. 695 sobre causas de oposición a la ejecución).

Ulteriores cambios normativos en el procedimiento hipotecario regulado en la LEC llevó a cabo la Ley 19/2015 de Medidas de reforma administrativa en el ámbito de la Administración de Justicia y del Registro Civil (vid. al respecto, ACHÓN BRUÑEN, $\mathrm{M}^{\mathrm{a}}$.J., "Comentario crítico de las modificaciones introducidas en el procedimiento de ejecución hipotecaria por la Ley 19/2015, de 13 de julio", La Ley, $\mathrm{n}^{\circ} .8619,2015$ ).

Vid. Directiva 93/13/CEE del Consejo, de 5 de abril, sobre las cláusulas abusivas en los contratos celebrados con consumidores.

22 Vid. en especial la célebre Sentencia del Tribunal de Justicia de la Unión Europea de 14 de marzo de 2013 (Asunto C-415-11 [TJCE 2013\89]); sentencia, comúnmente conocida como «caso Aziz», que ha sido objeto de una gran atención doctrinal: entre otros muchos, por BERROCAL LANZAROT, A.I., "La protección del deudor hipotecario a propósito de la sentencia del Tribunal de Justicia de la Unión Europea, sala primera, de 14 de marzo de 2013", Revista Aranzadi doctrinal, no .2, 2013, pp. 213-250; ACHÓN BRUÑÉN, Ma.J., "Adecuación del procedimiento judicial hipotecario a la normativa europea: Sentencia del TJUE de 14 de marzo de 2013", La Ley, n'.8065, pp. 1-17; CORDERO LOBATO, E., "Control judicial sobre cláusulas abusivas y ejecuciones hipotecarias", Revista Aranzadi Doctrinal, no .2, 2013, pp. 2015-212; ESTRADA ALONSO, E. FERNÁNDEZ CHACÓN, I., "El futuro de la ejecución hipotecaria española tras la sentencia del Tribunal de Justicia de la Unión Europea, de 14 de marzo de 2013", RCDI, $\mathrm{n}^{\circ} .737,2013$, pp. 1415-1476; PÉREZ CONESA, C., "Cláusulas abusivas, préstamo hipotecario y legislación interna: su reforma «a remolque» de la doctrina del Tribunal de Justicia de la Unión Europea", $A C-M, \mathrm{n}^{\circ} .5,2015$; y MARCOS FRANCISCO, D., "Consumidores, sujetos privilegiados en el nuevo paradigma de justicia civil europea: medidas procesales y extraprocesales para su protección”, InDret, nº.3, 2015, pp. 34-45.

Vid. además, ya con posterioridad a la Ley $1 / 2013$, entre las resoluciones más significativas del TJUE su Sentencia de 17 julio 2014 (TJCE 2014/106) -comentada por CARRASCO PERERA, Á./LYCZKOWSKA, K., "Un nuevo (y esta vez defectuoso) pronunciamiento del TJUE sobre el procedimiento hipotecario español", Publicaciones Jurídicas CESCO, 21 julio 2014; PÉREZ DAUDÍ, V., "Las consecuencias de la STJUE de 17 de julio de 2014 en el proceso de ejecución hipotecaria", La Ley, nº.8391, 2014, pp. 6-12; DÍEZ GARCÍA, H., "Igualdad de armas...", DPyC, n n $^{\circ} 28,2014$, pp. 241-258; y por PÉREZ CONESA, C., "STJUE de 17 de julio de 2014 (Asunto C-169/14): el art. 7.1 de la Directiva 93/13/CEE se opone a un sistema de procedimiento de ejecución hipotecaria, como el español, en el que el deudor ejecutado no puede recurrir en apelación contra la resolución que desestima su oposición a la ejecución", $A C-M, n^{\circ} .8,2014$-; la STJUE de 21 enero 2015 (TJCE 2015/4) -comentada por SABATER BAYLE, E., "Intereses moratorios en contrato de préstamo hipotecario, Cláusula abusiva. Nulidad o moderación judicial", $A C-M, \mathrm{n}^{\circ} .3,2015$; MARCOS FRANCISCO, D., "Consumidores...", InDret, n n.3, 2015, pp. 31-33; y ACHÓN BRUÑEN, M".J., "Diversidad de criterios judiciales en relación con los efectos de la declaración de nulidad de las cláusulas relativas a intereses en las escrituras de hipoteca. La esperada STJUE de 21 de enero de 2015: una luz con muchas sombras", La Ley, no.8473, 2015-; y la Sentencia de 29 octubre 2015 (JUR 2015\248737) -comentada por GONZÁLEZ CASSO, J., "Otro puyazo a nuestro legislador. Comentario a la sentencia del TJUE de 29 de octubre de 2015", La Ley, no 8670 , 2015; y por LYCZKOWSKA, K., "El plazo para oponerse a la ejecución establecido por la Disposición Transitoria $4^{\mathrm{a}}$ de la Ley $1 / 2013$ se opone a la normativa comunitaria", Publicaciones Jurídicas CESCO, 9 noviembre 2015, pp. 1 a 5-. Vid. asimismo, los Autos del TJUE de 5 junio 2014 (TJCE 2014\345), 11 junio 2015 (TJCE 2015\224) y 16 julio 2015 
oposición del deudor a la ejecución hipotecaria a través de la alegación de la existencia de cláusulas abusivas en el préstamo hipotecario suscrito (art. 695.1.4 LEC) ${ }^{24}$. Si tal control judicial de abusividad (sobre todo, de cláusulas suelo ${ }^{25}$, de

(TJCE 2015\327) -comentado por RODRÍGUEZ CÁRCAMO, J.M., "Los asuntos Sánchez Morcillo: el recurso de apelación en el procedimiento de ejecución hipotecaria y el Derecho de la UE", La Ley, no.8613, 2015; y por LYCZKOWSKA, K., "El TJUE confirma que la regulación española actual de la oposición en el procedimiento de ejecución hipotecaria es conforme al Derecho comunitario", Publicaciones Jurídicas CESCO, 28 agosto 2015, pp. 1 a $3-$.

23 Un nuevo revés a nuestra legislación hipotecaria procede del Comité de Derechos Económicos, Sociales y Culturales de Naciones Unidas que, en Dictamen de 17 de junio de 2015, resolvió amonestar a España por un proceso de ejecución hipotecaria en el que la notificación de la demanda no se había realizado, según el Comité, con las debidas garantías y se había vulnerado, en consecuencia, el derecho a la vivienda de la actora, establecido en el art. 11.1 del Pacto Internacional de Derechos Económicos, Sociales y Culturales. Afirmó a este respecto el Dictamen que los Estados parte deben garantizar que las personas cuyo derecho a la vivienda adecuada pudiera ser afectado por desalojos forzados o ejecuciones hipotecarias dispongan de un proceso judicial y unos recursos efectivos y apropiados. Con base a ello, el Comité de la ONU estableció en el presente asunto la obligación del Estado español de proporcionar a la actora una reparación efectiva y de emprender las reformas legislativas oportunas para asegurar la conformidad de nuestro sistema hipotecario con el citado Pacto Internacional (Diario La Ley, 30 septiembre 2015).

24 Entre la ingente literatura jurídica sobre el tema, vid. CARRASCO PERERA, Á., "La Ley $1 / 2013$, de 14 de mayo, de reforma hipotecaria y la articulación procesal del control sobre cláusulas abusivas en la ejecución hipotecaria”, Publicaciones Jurídicas CESCO, 2013; CORDERO LOBATO, E., "Y ahora viene lo difícil: ¿Cómo controlar en el ejecutivo hipotecario el carácter abusivo de una cláusula?", Revista CESCO, nº.5, 2013, pp. 32 y ss.; DOMÍNGUEZ RUIZ, L., "El control judicial de cláusulas abusivas en el proceso de ejecución tras la reforma de la Ley 1/2013, de 14 de mayo", Revista General de Derecho Procesal [en adelante RGDProc.], n⿳..35, 2015; FERNÁNDEZ SEIJO, J.M., La defensa de los consumidores en las ejecuciones hipotecarias, Barcelona, Bosch, 2013; PERTíÑZ VÍLCHEZ, F., "Las cláusulas abusivas en los procesos de ejecución hipotecaria", en Desahucios y ejecuciones hipotecarias (un drama social y un problema legal), Valencia, Tirant lo Blanch, 2014, pp. 279 y ss.; SENÉS MOTILLA, C., "La reforma de la ejecución ordinaria e hipotecaria", en $L a$ protección del deudor hipotecario Aproximación a la Ley de Medidas para reforzar la protección a los deudores hipotecarios, reestructuración de deuda y alquiler social, Granada, Comares, 2014; ANTA GONZÁLEZ, J.F., "Una aproximación crítica a la Ley 1/2013, de 14 de mayo, de medidas para reforzar la protección a los deudores hipotecarios", La Ley, n' ${ }^{\circ} .8237$, 2014; LAFUENTE TORRALBA, A.J., "El control judicial de cláusulas abusivas en la ejecución hipotecaria: luces y sombras de su regulación legal", en Vivienda y crisis económica, Cizur Menor, Aranzadi, 2014, pp. 219-255; y "Los obstáculos para el examen de cláusulas abusivas en el proceso de ejecución: puntos ciegos y zonas de desprotección en el régimen vigente", RDCiv., $\mathrm{n}^{\circ} .2,2015$, pp. 181-205.

25 Vid. p.ej. BARRAL VIÑALS, I., “¿Abusivas por falta de transparencia (bancaria)?: El control de incorporación y las cláusulas suelo en préstamos hipotecarios”, Revista de Derecho Privado [en adelante $R D P$ ], $\mathrm{n}^{\circ} .2,2015$, pp. 25-70; LÓPEZ JIMÉNEZ, J.M. (Dir.), La cláusula suelo en los préstamos hipotecarios, Barcelona, Bosch, 2013; PERTíÑEZ VÍLCHEZ, F., "Falta de transparencia y carácter abusivo de la cláusula suelo en los contratos de préstamo hipotecario", InDret, $n^{\circ} .3,2013$; MARTÍNEZ ESCRIBANO, C., "El control de transparencia y la validez de las cláusulas suelo", en Cláusulas suelo: ¿Se puede negociar con el banco?, Cizur Menor, 
vencimiento anticipado ${ }^{26}$ o de intereses de demora $\left.{ }^{27}\right)^{28}$ juega un papel determinante en un elevado porcentaje de los procesos de desahucio hipotecario, tampoco cabe ignorar, no obstante, que, según datos del VI Informe emitido el 23 de octubre de 2015 por la Comisión de Control y Seguimiento del Código de Buenas Prácticas ${ }^{29}$, desde que éste se pusiera en marcha en $2012^{30}$ más de veinte mil familias

Aranzadi, 2014, pp. 13-40; MORENO GARCÍA, L., Cláusulas suelo y control de transparencia. Tratamiento sustantivo y procesal, Madrid, Marcial Pons, 2015, pp. 192-197. Vid. sobre el particular, p.ej. LYCZKOWSKA, K., "¿Quedan todavía cláusulas de vencimiento anticipado no abusivas?”, Publicaciones Jurídicas CESCO, 25 noviembre 2015, pp. 1-4.

27 Vid. al respecto, entre otros, MARÍN LÓPEZ, M.J., "Los intereses moratorios abusivos e intereses moratorios ilegales en la Ley 1/2013", Publicaciones Jurídicas CESCO, 11 octubre 2013, pp. 1-11; MIRALBELL GUERIN, L.M., "El revuelo de las cláusulas abusivas en las hipotecas", La Ley, no.8214, 2013; BALLUGERA GÓMEZ, C., "Tope máximo de intereses de demora", RDCiv., no.1, 2014, pp. 103-120.

Vid. ALONSO PÉREZ, Mª.T., "Cláusulas frecuentes en préstamos hipotecarios para adquisición de vivienda: cláusula suelo, cláusula de vencimiento anticipado y cláusula de intereses moratorios excesivamente elevados (en particular, su posible carácter abusivo)", en Vivienda y crisis económica, Cizur Menor, Aranzadi, 2014.

29 Este informe se puede consultar en http://www.mineco.gob.es/stfls/mineco/economia/ ficheros/pdf/VI_Informe_cumplimiento_CBP.pdf.

Téngase en cuenta que el pasado 27 de enero de 2016 se abrió una nueva sección en la página web del Ministerio de Economía y Competitividad dedicada al Código de Buenas Prácticas para la reestructuración viable de las deudas con garantía hipotecaria sobre la vivienda habitual (http://www.mineco.gob.es/portal/site/mineco/menuitem.32ac44f94b634f76

faf2b910026041a0/?vgnextoid=d43ad0d172ff7310VgnVCM1000001d04140aRCRD). En esta nueva sección están publicados los informes semestrales de la Comisión de Control sobre el cumplimiento de dicho Código de Buenas Prácticas (art. 6.4 RD-Ley 6/2012). Asimismo, se incluye información sobre las entidades adheridas, los requisitos que se deben cumplir para pedir la aplicación del citado Código a una deuda hipotecaria, el procedimiento a seguir para presentar una reclamación por incumplimiento del Código de Buenas Prácticas, así como un compendio de las consultas más frecuentes relacionadas con el mismo. Vid. al respecto, AGÜERO ORTIZ, A., "Nueva Sección dedicada al Código de Buenas Prácticas Bancarias en la Web del Ministerio de Economía y Competitividad", Publicaciones Jurídicas CESCO, 18 febrero 2016, pp. 1-4.

30 Recuérdese que, conforme al párr. 1 del 5 del RD-Ley 6/2012, "el Código de Buenas Prácticas incluido en el Anexo será de adhesión voluntaria por parte de las entidades de crédito o de cualquier otra entidad que, de manera profesional, realice la actividad de concesión de préstamos o créditos hipotecarios" (vid. el amplísimo elenco de entidades adheridas, en la Resolución de 23 de octubre de 2015, de la Secretaría de Estado de Economía y Apoyo a la Empresa, en la que se publica la lista de entidades que han comunicado su adhesión al Código de Buenas Prácticas, actualizada al tercer trimestre de 2015). Ahora bien, según dispone el párr. 4 de ese mismo art. 5 RD-Ley 6/2012, "desde la adhesión de la entidad de crédito, y una vez que se produzca la acreditación por parte del deudor de que se encuentra situado dentro del umbral de exclusión, serán de obligada aplicación las previsiones del Código de Buenas Prácticas". Además, y aun cuando el párr. 7 de dicho art. 5 establece expresamente que "el contenido del Código de Buenas Prácticas resultará de aplicación exclusiva a las entidades adheridas, deudores y contratos a los que se refiere este Real Decreto-ley", a renglón seguido matiza el párr. 8 que "sin perjuicio de lo dispuesto en el apartado anterior, las entidades adheridas podrán con carácter puramente potestativo aplicar las previsiones del Código de Buenas Prácticas a deudores distintos de los comprendidos en el artículo 3 y podrán, en todo caso, en la aplicación del Código, mejorar las previsiones contenidas en el mismo". 
hipotecadas y en apuros se han beneficiado de las medidas en él previstas ${ }^{31}$ : concretamente, de un total de 23.640 operaciones, se ha efectuado una reestructuración de la deuda pendiente en 18.620 casos, se ha procedido a una dación en pago de la vivienda con la extinción de la deuda en 5.014 y en 6 ocasiones se ha efectuado una quita ${ }^{32}$.

Con todo, y sin perjuicio de lo dicho, no pocas de las aludidas reformas implantadas en pleno escenario de la crisis -e introducidas mediante un constante goteo normativo, desordenado, fragmentario e inconexo ${ }^{33}$ - se han hecho a trompicones, de forma apresurada y poco meditada ${ }^{34}$, para "parchear" a posteriori errores,

La interpretación coordinada de las precedentes normas permite afirmar, por un lado, que la aplicabilidad del Código de Buenas Prácticas está condicionada a que las entidades acreedoras manifiesten su voluntad de regirse por él mediante su adhesión al mismo; presupuesto de la voluntariedad que no es óbice para que, una vez que las partes hayan optado por someterse a la aplicación del Código (la entidad mediante su adhesión, y el deudor solicitando alguna de las medidas en él previstas), éstas tengan eficacia obligatoria -lo que ha llevado a hablar de "negociaciones semi-forzosas" enmarcadas en un Código voluntario (NASARRE AZNAR, S./SIMÓN MORENO, H., "Un paso más en la protección de los deudores hipotecarios de vivienda: la Directiva 2014/17/UE y la reforma del Código de Consumo de Cataluña por Ley 20/2014", $R D B B, n^{\circ} .139,2015$, p. 12)-. Por otro lado, y si bien el Código de Buenas Prácticas no debe aplicarse a más casos que aquellos para los que está previsto, existe la posibilidad de ir más allá -de aplicar las medidas de dicho Código a supuestos y sujetos distintos de los estrictamente contemplados- si concurre en tal sentido la voluntad del acreedor hipotecario. Vid. sobre estas cuestiones vinculadas a la naturaleza y eficacia del Código de Buenas Prácticas, por ej. ALONSO PÉREZ, Mª.T., "El Código de Buenas Prácticas...", RDCiv., no.2, 2015, pp. 34-38, 46-48; VIGIL DE QUIÑONES OTERO, D., "El Registro, la hipoteca, los consumidores y la autorregulación de los acreedores", en Códigos de Conducta y préstamos hipotecarios, Madrid, Dykinson, 2013, p. 61; y SERRANO, I., "Soluciones legales en materia de desahucios...", RJNot., no.86-87, 2013, pp. 169-170, quien pone de relieve que "a las entidades bancarias les interesa muy mucho aplicar estas prácticas que se califican de «buenas», porque, para ellas es mejor cobrar a más largo plazo, que tener que ejecutar el crédito".

31 Además de haberse suspendido 17.551 lanzamientos.

32 De este último Informe de 2015 y de los previamente emitidos por dicha Comisión de Control en años anteriores -informes de 2012, 2013 y 2014, disponibles todos ellos en la página web del MINECO (www. mineco.gob.es/stfls/mineco/prensa/ficheros/noticias)-, se desprende que, en la práctica, en torno al 65 o 70\% de las solicitudes a las que se aplica el Código de Buenas Prácticas se resuelven con una reestructuración de la deuda, de un 24 a un 33\% se zanjan con la dación en pago y la quita apenas se aplica.

33 ALCALÁ DİAZ, Má.Á., "La protección del deudor hipotecario. La insuficiencia de la reforma para la defensa del deudor-consumidor", La Notaría, no.2, 2013, p. 7; y SÁNCHEZ HERNÁNDEZ, C., "Garantía hipotecaria, mercado y crisis...", RDPatr., nº.35, 2014 critican que, en lugar de haberse abordado una reforma integral de la normativa sustantiva y procesal reguladora de los créditos hipotecarios -como habría sido deseable-, las numerosas intervenciones legislativas, a veces con pocos meses de distancia entre unas y otras, se hayan realizado de forma prácticamente superpuesta y por completo "descoordinada".

34 También LÓPEZ AZCONA, A., "El ámbito de aplicación de las medidas de protección de los deudores hipotecarios...", $R G L J, \mathrm{n}^{\mathrm{o}} .1,2015$, pp. 30 y 68 opina que la elaboración de estas normas se realizó con excesiva "premura", de modo "precipitado" e "improvisado". De "soluciones improvisadas" habla igualmente BASTANTE GRANELL, V., "Mediación 
deficiencias y vacíos legales preexistentes; todo lo cual puede llegar a distorsionar principios fundamentales de nuestro ordenamiento iusprivatista ${ }^{35}$, a poner en jaque ciertos postulados generales clásicos del Derecho de la contratación y del pago de las obligaciones, a desdibujar la fisonomía estructural propia de la garantía real hipotecaria y de su realización ${ }^{36} \mathrm{y}$, a la postre, a generar una confusión e inseguridad jurídica considerables ${ }^{37}$.

hipotecaria: una solución al problema del sobreendeudamiento de los particulares", Anales de Derecho, $n^{\circ} .31,2013$, p. 183.

En esta misma línea, SERRANO GARCÍA, I., "Soluciones legales en materia de desahucios...", RJNot., no.86-87, 2013, pp. 97, 102-104 y 106 se ocupa detenidamente de desgranar los pilares y principios del Derecho civil patrimonial (tanto en materia de Derecho de Obligaciones, como de Derechos Reales) que han sido violentados o gravemente subvertidos por tales reformas legales -a las que llega a calificar de "esquizofrenia legislativa" (p. 151, n.42)-. "Debemos tener sumo cuidado -afirma- con estos experimentos que cuestionan principios generales del Derecho e instituciones muy antiguas e instaladas en el comercio jurídico desde la noche de los tiempos. Intentar solucionar problemas económicos (con consecuencias sociales) modificando normas jurídicas civiles, no me parece la solución más adecuada".

36 También alerta de esos peligros ALONSO PÉREZ, Ma.T., "El Código de Buenas Prácticas...", RDCiv., $\mathrm{n}^{\circ} .2,2015$, p. 62 cuando escribe que el Código de Buenas Prácticas "está regulando una situación de sobreendeudamiento caracterizada porque la deuda que provoca esa situación está garantizada por hipoteca. Y creo que se debe ser muy prudente, ya que cualquier modificación normativa en este ámbito puede suponer una reducción de la eficacia del mecanismo más fuerte de que disponemos para garantizar el cumplimiento de las obligaciones asumidas. La hipoteca es fuente de riqueza, ofrece la posibilidad al ciudadano de clase media de acceder a la propiedad de su vivienda o de emprender un negocio; debilitar jurídicamente su eficacia para ofrecer al deudor-consumidor un beneficio en una concreta y puntual coyuntura económica, puede suponer graves costes, ya no sólo para los particulares, sino para la economía del país". Vid. en la misma línea SÁNCHEZ HERNÁNDEZ, C., "Garantía hipotecaria, mercado y crisis...”, RDPatr., nº.35, 2014; y GONZÁLEZ SÁNCHEZ, S., "Debate global con un claro análisis coste-beneficio", Escritura Pública, nº.12, 2013.

Como también críticamente señala en la presentación de su monografía CASTILLO MARTÍNEZ, C. del C., Las cláusulas abusivas en los contratos de préstamo garantizado con hipoteca. Negociación contractual, desequilibrio importante y protección del consumidor en la contratación bancaria, Valencia, Tirant lo Blanch, 2016, "con un complejo y atiborrado panorama normativo nacional en el que dudosamente parece regir el imperio de la ley, los órganos judiciales patrios en titubeante dispersión de criterios, el Tribunal de Justicia de la Unión Europea convertido en un sobresaltado legislador -también procesal- civil español, los ojos de Europa expectantes ante el hundimiento de un sistema inveteradamente intocable de aseguramiento crediticio, y hasta la ONU denunciando a España por incumplimiento de las leyes internacionales sobre el derecho a la vivienda, la situación resulta, a todas luces, cuanto menos inquietante". Inquietante al tiempo que "perturbadora" pues "asistimos, sin duda, al deceso de la garantía real más genuina de entre las destinadas a la obtención de un préstamo por parte de un consumidor"; garantía hipotecaria "en crepuscular irreversible decadencia, interpretando un guión ya caduco y resistiendo los embates de un tirano director y los vituperios de una grada insatisfecha y enojada".

37 Como ya en relación con las propuestas de reforma afirmara GARCÍA CRESPO, J.M., "Mercado hipotecario y seguridad jurídica", La Ley, no.7661, 2011, resulta preocupante que las mismas se estén efectuando, no solo "con ostentación de un manifiesto desconocimiento de la materia hipotecaria a la que afectan, sino con épico desprecio al principio de seguridad jurídica". 
A mi juicio, desde el punto de vista de las soluciones ofrecidas por el Derecho Privado, el punto de mira ha de dirigirse, primordialmente, a los mecanismos de prevención del sobreendeudamiento del consumidor de crédito: ex ante es cuando deben reforzarse los deberes de información al consumidor (tanto en el iter contractual como en la fase publicitaria y precontractual ${ }^{38}$ ); ex ante es cuando deben imponerse con rigor deberes de transparencia bancaria a las entidades crediticias ${ }^{39} \mathrm{o}$ articularse test de solvencia del consumidor para evaluar, con carácter previo a la contratación, su capacidad de pago y concederle o no el crédito ${ }^{40}$; pluralidad de garantías en favor del prestatario ${ }^{41}$ que hoy prevé ya la Directiva $17 / 2014^{42}$, sobre

38 Vid. p.ej. HERNÁNDEZ SAINZ, E., "El nuevo régimen de protección precontractual en la contratación bancaria de préstamos hipotecarios", en Vivienda y crisis económica, Cizur Menor, Aranzadi, 2014, pp. 59-122.

39 Con detalle sobre las normas de transparencia bancaria aplicables a los créditos hipotecarios, vid. entre otros, PÉREZ DE MADRID CARRERAS, V., "La protección del consumidor en la contratación bancaria", en Derecho (privado) de los consumidores, Madrid, Marcial Pons, 2012, pp. 423 y ss.; MIRANDA SERRANO, L.M., "Operaciones y contratos bancarios", en Derecho Mercantil, Vol.7 , dir. por JIMÉNEZ SÁNCHEZ, G.J./DÍAZ MORENO, A., Madrid, Marcial Pons, 2013, pp. 63 y ss.; ÁLVAREZ OLALLA, Ma.P., "La nueva normativa en materia de transparencia de servicios bancarios. La regulación del préstamo", $A C-M, \mathrm{n}^{\circ} .10$, 2012, pp. 23 y ss.; BERROCAL LANZAROT, A.I., "La protección del deudor hipotecario en el actual contexto de crisis económica", Cuadernos de Derecho y comercio, $\mathrm{n}^{\circ} .58,2012$, pp. 13 y ss.; y MARTÍNEZ ESPÍN, P., "El régimen de transparencia y protección del cliente de servicios bancarios", Revista CESCO, n ${ }^{\circ} .5,2013$, pp. 81 y ss.

En el mismo ámbito de los préstamos hipotecarios, se manifiesta firmemente defensora de la eficacia directa inter privatos de la normativa de transparencia bancaria, BARRAL VIÑALS, I., “¿Abusivas por falta de transparencia (bancaria)?...”, $R D P, \mathrm{n}^{\circ} .2,2015$, pp. 25-70, en especial pp. 46-48.

40 Ya el Informe del Defensor del Pueblo sobre «Crisis económica y deudores hipotecarios: actuaciones y propuestas del Defensor del Pueblo» -tanto en su versión de 25 de enero de 2012 (https://www.defensordelpueblo.es/wp-content/uploads/2015/05/2012-01-Crisis-económica-ydeudores-hipotecarios-actuaciones-y-propuestas-del-Defensor-del-Pueblo.pdf) como en su actualización a 9 de abril de 2013 (https:/www.defensordelpueblo.es/wp-content/uploads/ historico/es/Documentacion/Publicaciones/monografico/Documentacion/informe_deudores_hi potecarios.pdf)- subraya que "la banca debería siempre evaluar la capacidad de endeudamiento del cliente y abstenerse de ofrecer préstamos por encima de la capacidad de reembolso".

Acerca de la normativa que, en desarrollo del llamado principio de préstamo responsable, establece el deber de evaluación de la solvencia de los clientes de las entidades de crédito, vid. p.ej. CUENA CASAS, M., "Préstamo responsable, información crediticia y protección de datos personales", Revista de Derecho Concursal y Paraconcursal, n.20, 2013, pp. 161 y ss.; DE LA PEÑA, L./LÓPEZ-FRÍAS, J., "Crédito responsable: un nuevo concepto en nuestro

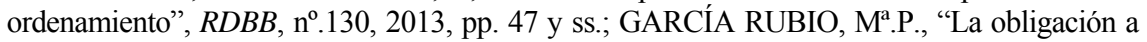
cargo del profesional de evaluar la solvencia del consumidor prestatario", La Ley-Unión Europea, no.16, 2014, pp. 49 y ss.; y ÁLVAREZ LATA, N., "Notas a la STJUE de 18 de diciembre 2014. Obligaciones derivadas del principio de crédito responsable: primeras interpretaciones del TJUE", Revista CESCO, nº.13, 2015, pp. 245-256.

41 Medidas que, no obstante, ha de reconocerse que favorecen también -y tanto o más que al consumidor- al propio prestamista. Vid. en este sentido, AGÜERO ORTIZ, A., "Comentario e interpretación de la nueva Directiva en materia hipotecaria (Directiva 2014/17/UE). Una 
los Contratos de crédito celebrados con consumidores para bienes inmuebles de uso residencial ${ }^{43}$.

Sin embargo, nuestro legislador y nuestros gobernantes, ni con partidos conservadores ni con otros más progresistas, se preocuparon suficientemente en su

Directiva para proteger a las entidades de crédito y a la propia Unión Europea”, Publicaciones Jurídicas CESCO, julio 2014, pp. 1-30.

42 Para un estudio de dicha normativa en esta Directiva 2014/17/UE, de 4 de febrero, del Parlamento Europeo y del Consejo, vid. entre otros, RAMOS HERRANZ, I., "Directiva sobre contratos de crédito para bienes inmuebles", Revista de Derecho de los Negocios, $\mathrm{n}^{\circ} .248,2011$, pp. 27 y ss.; CATENA REAL, R., "La reciente normativa en materia de transparencia referida a los préstamos hipotecarios", La Ley, n'.8402, 2014; GÓMEZ LOZANO, M".M., "Las medidas de protección del consumidor en la fase previa de contratación de préstamos hipotecarios: de la normativa española a la comunitaria", en La protección de los consumidores en tiempos de cambio, Madrid, Iustel, 2015, pp. 391 y ss.; y NASARRE, S./SIMÓN, H., "Un paso más en la protección de los deudores hipotecarios de vivienda: la Directiva 2014/17/UE...", $R D B B, \mathrm{n}^{\mathrm{o}} .139,2015$, pp. 16-21 y 53, para quienes la Directiva 2014/17 aborda "de manera «descafeinada» cuestiones clave como la ejecución hipotecaria, las medidas de prevención del sinhogarismo, la dación en pago, el derecho inherente al prepago por el deudor o no aclarando la prohibición de concesión de préstamos hipotecarios a aquellos que no los puedan repagar". En relación con la Propuesta de 31 de marzo de 2011 de dicha Directiva, vid. LAUROBA LACASA, E., "La Propuesta de Directiva del Parlamento Europeo y del Consejo sobre los Contratos de crédito relativos a los bienes inmuebles de uso residencial", en Garantías reales en escenarios de crisis: presente y prospectiva, Madrid, Marcial Pons, 2012, pp. 117-132; MONDÉJAR PEÑA, M.I., "La protección de los deudores hipotecarios frente a las ejecuciones hipotecarias de viviendas en tiempos de crisis", en Garantías reales en escenarios de crisis: presente y prospectiva, Madrid, Marcial Pons, 2012, pp. 580-581; y ROY PÉREZ, C., "La protección del consumidor en la contratación de productos y servicios bancarios...", en Garantías reales en escenarios de crisis..., 2012, pp. 464-468.

Un análisis particular de la repercusión de la Directiva 2014/17 sobre la Orden EHA/2899/2011, de 28 de octubre, sobre transparencia y protección del cliente de servicios bancarios (desarrollada por la Circular del Banco de España 5/2012, de 27 de junio, sobre transparencia en los servicios bancarios y responsabilidad en la concesión de préstamos) -en especial, respecto a la proyección de este régimen en la órbita del contrato de préstamo hipotecario- puede verse en CASADO NAVARRO, A., "La normativa española sobre transparencia de préstamos hipotecarios ante la Directiva 2014/17/UE reguladora de los contratos de crédito para bienes inmuebles de uso residencial celebrados con consumidores", La Ley, $\mathrm{n}^{\circ} .8636,2015$.

43 También ha incorporado todo ese elenco de obligaciones de transparencia, información contractual y previa al contrato, publicidad, deber de evaluación de la solvencia del prestatario, fortalecimiento del rol notarial, etc. el Código catalán de Consumo (Ley 22/2010, de 20 de julio) en los nuevos artículos 261-1 a 263-2, introducidos por la Ley 20/2014 -Ley que, a modo de avanzadilla en Cataluña, "implementa" en buena parte las orientaciones de la Directiva 17/2014 (vid. un estudio pormenorizado de la citada Ley catalana 20/2014 en NASARRE, S./SIMÓN, H., "Un paso más en la protección de los deudores hipotecarios de vivienda...", $R D B B, \mathrm{n}^{\circ} .139,2015$, pp. 25 a 46)-. Sin embargo, por Providencia de 6 de octubre de 2015 (JUR 2015 2239027), el TC suspendió la vigencia y aplicación de tales preceptos (ex art. 161.2 CE), con efectos desde la fecha de interposición del recurso de inconstitucionalidad interpuesto contra los mismos (30 de septiembre de 2015).

Asimismo regula específicamente la protección de los consumidores mediante la transparencia en la contratación hipotecaria la Ley 1/2012, de 26 de marzo, de la Comunidad de Madrid. 
momento de controlar y prevenir los excesos cometidos durante el anterior periodo de expansión crediticia ni pusieron la debida atención en esos mecanismos preventivos del sobreendeudamiento; y fue luego -cuando podríamos decir, en términos un tanto pedestres, que ya era tarde y que "a lo hecho, pecho"- cuando trataron de buscar remedios (o remiendos) a la acuciante y dramática situación creada, a través de las antes mencionadas medidas ex post ${ }^{44}$-dictadas, a veces, por vía de urgencia y a golpe de Real Decreto ${ }^{45}$-.

Pienso, en definitiva, que en el delicado entramado de intereses jurídicos contrapuestos que plantean las ejecuciones hipotecarias, se percibe una cierta politización del tema -donde parecieran contar más los votos que las garantías-. Pienso que, en el afán de proteger al deudor frente al desahucio de la vivienda

44 En sentido crítico con la pretendida eficiencia de estas medidas ex post, vid. también BLANCO GARCÍA, A.I., "La intermediación hipotecaria...", RIEDPA, no.2, 2015, pp. 10-12; BASTANTE GRANELL, V., "Mediación hipotecaria...", Anales de Derecho, $\mathrm{n}^{\circ} .31,2013$, p. 184; RODRÍGUEZ LÓPEZ, J., "Ejecuciones hipotecarias...”, RDCiv., $\mathrm{n}^{\circ} .3$, 2014, pp. 111-118; MOLLAR Y PIQUER, Mª.P./VILAR GONZÁLEZ, S., "El consumidor frente a la ejecución hipotecaria", Revista jurídica de la Región de Murcia, nº.46, 2013; RODRÍGUEZ PRIETO, F., "La nueva ley de protección de los deudores hipotecarios: poco más (y de lo mismo)", ¿Hay Derecho?, 13 mayo 2013; y ZURITA, I., "Reflexiones sobre la ampliación del umbral de exclusión y el ámbito de aplicación del Código de Buenas Prácticas...", La Ley, n.8520, 2015; autora para la que las referidas medidas encaminadas a conseguir el descenso del número de ejecuciones hipotecarias no parecen haber tenido el éxito esperado y resultan poco adecuadas para acabar con los lanzamientos de su vivienda de las familias sobreendeudadas como consecuencia de una crisis económica sin precedentes.

Asimismo SERRANO GARCÍA, I., "Soluciones legales en materia de desahucios...", RJNot., $\mathrm{n}^{\circ} .86-87,2013$, p. 97 ha señalado que "vanamente se pretende resolver (o aliviar) la situación de los deudores con una serie de medidas jurídicas, que pueden mejorar levemente su situación, pero nunca remediarla".

Muy acertadamente, SÁNCHEZ HERNÁNDEZ, C., "Garantía hipotecaria, mercado y crisis...", RDPatr., $\mathrm{n}^{\circ} .35,2014$ analiza con espíritu crítico las «soluciones» legislativas adoptadas tendentes a proteger «hipotéticamente» al deudor hipotecario, subrayando lo inadecuado de tomar "medidas una vez que la crisis ha estallado y se hecho pública. Hubiera sido necesario -afirma- que los poderes públicos adoptaran, en su momento, medidas anticipativas que hubieran permitido paliar sus consecuencias, lo que advierte de la falta de conciencia en torno a la profundidad y trascendencia de la situación que venimos padeciendo". Habría sido de crucial importancia articular antes de la crisis "medidas tendentes a evitar estas situaciones, intentando fomentar un «endeudamiento responsable» a través, entre otras cosas, de la concesión de «créditos responsables»"“.

Dentro de ese trasiego normativo, cabe recordar, primeramente, el RD-Ley 8/2011, de 7 de julio, de Medidas de Apoyo a los Deudores Hipotecarios -Real Decreto calificado como una "reforma demagógica" y duramente criticado por CARRASCO PERERA, Á., "Tipo para subastas hipotecarias, rehabilitaciones, declaraciones de obra nueva y otras regulaciones inmobiliarias en el RD-Ley 8/2011”, La Ley, $\mathrm{n}^{\circ} .7698$, 2011-. Menos de un año después, llegó el RD-Ley 6/2012, de 9 de marzo, de Medidas Urgentes de Protección de Deudores Hipotecarios sin Recursos; seguidamente el RD-Ley 27/2012, de 15 de noviembre, de Medidas Urgentes para reforzar la Protección a los Deudores Hipotecarios; y ya con posterioridad, el RD-Ley 1/2015, de 27 de febrero, de Mecanismo de Segunda Oportunidad, reducción de carga financiera y otras medidas de orden social. 
habitual, se ha dictado no poca legislación demagógica; rasgo éste que, como luego tendré la oportunidad de exponer, sobresale en buena medida en el fomento extremo de la cultura de la "negociación" y del "diálogo"

\section{Medidas de orden público y social paliativas del "sinhogarismo"}

Continuando con el discurso anterior, y aunque acaso pueda sonar políticamente incorrecto expresarlo en términos tan rotundos, creo que en el Estado (Social) de Derecho la política no se puede hacer a costa de la legalidad. Dicho de otro modo, la justicia social no debe hacerse a costa del Estado de Derecho, porque sacrificar los fundamentos de éste y de su legalidad puede abrir las puertas a injusticias radicales. En el Estado de naturaleza siempre gana el fuerte, y no hace falta ser un hobbesiano convencido para comprenderlo. En el Estado de Derecho también gana el fuerte muchas veces. Pero no es enmendando la plana a la legalidad como podremos defender al débil, sino modificando los efectos (perversos) de aquélla cuando sea posible. Y en el caso que nos ocupa lo es.

En efecto, nos puede parecer de profunda injusticia social y humana -y lo es- que muchas familias, sobreendeudadas e imposibilitadas por la coyuntura económica para afrontar sus deudas hipotecarias ${ }^{47}$, sean desahuciadas de su vivienda. Pero, ante eso, para suavizar y remover las nefastas y devastadoras consecuencias de la crisis -que muestra en los lanzamientos hipotecarios su cara más cruel-, para corregir los perniciosos e indeseables desequilibrios que origina la economía de mercado, póngase en marcha la actividad pública propia de un Estado Social ${ }^{48}$, bríndense ayudas sociales y articúlense medidas públicas ${ }^{49}$.

46 En expresión de ANTONIAZZI, C., "Consideraciones acerca de la mediación ante la crisis económico-social actual”, RGDProc., $\mathrm{n}^{\circ} .17,2009$.

47 Como con carácter general ha escrito ROJO FERNANDEZ-RÍO, Á.J., "Problemas y cuestiones en torno al sobreendeudamiento e insolvencia de las familias españolas", en El futuro de la protección jurídica de los consumidores, Cizur Menor, Thomson-Civitas, 2008 , p. 754 , "el deudor hipotecario está siempre al filo de la navaja", de modo que "cualquier modificación de su capacidad financiera afecta sin duda a los pagos debidos".

48 Vid. la Exposición Motivos de la Ley 2/2014, de 20 de junio, de modificación de la Ley 2/2003 de Vivienda de Canarias y de medidas para garantizar el derecho a la vivienda; preámbulo en el que puede leerse que "la precariedad económica, laboral y social por la que atraviesan miles de familias obliga a poner en máxima tensión todos los mecanismos propios de un Estado social de Derecho, que, por definición, está llamado a corregir los desequilibrios que origina la economía de mercado. Uno de los ámbitos en los que se hace más evidente la necesidad de desplegar una actividad pública correctora es precisamente el de la vivienda".

49 También DÍEZ GARCÍA, H., "Igualdad de armas y tutela judicial...”, DPyC, no .28, 2014, p. 206 ha apuntado que al grave problema social de vivienda de aquellos que se han visto despojados de ella tras un proceso de ejecución hipotecaria, deben "hacer frente los poderes públicos con fondos públicos en cumplimiento del art. $47 \mathrm{CE}$ ". 
No en vano, y sin perjuicio de los incipientes y tímidos síntomas de recuperación económica $^{50}$, desde esta perspectiva - pública- las Administraciones y el legislador (tanto estatal como autonómicos) han dispuesto toda una batería de medidas que se traducen principalmente, de una parte, en el otorgamiento de prestaciones económicas ("de urgencia social") destinadas a evitar la llamada "exclusión social residencial" ${ }^{51}$ o el comúnmente denominado «sinhogarismo»" ${ }^{52}$ y, de otro lado, en la adjudicación de viviendas a través de bolsas de alquiler social ${ }^{53}$ y del Fondo Social de Viviendas ${ }^{54}$-mediante el cual se han adjudicado 4.000 viviendas desde el año

50 Por lo que concierne a nuestro estudio, y según datos del Consejo General del Poder Judicial, los desahucios de inmuebles (no sólo de viviendas) descendieron un 1,5\% interanual en el tercer trimestre de $2015 \mathrm{y}$, en concreto, las ejecuciones hipotecarias iniciadas entre el 1 de julio y el 30 de septiembre de 2015 fueron un 12,1\% menos que en el mismo periodo del año anterior, lo que sitúa este tipo de procedimientos en su nivel más bajo desde el mismo trimestre de 2008 (Diario de Noticias La Ley, 11-12-2015).

51 Entre otras normas autonómicas, contemplan este tipo de prestaciones económicas extraordinarias, por ejemplo la Ley 3/2015, de 18 junio, de Vivienda del País Vasco; la Resolución TES/7/2016, de 4 de enero, de la Agencia de la Vivienda de Cataluña, que establece las condiciones de acceso a las prestaciones económicas de especial urgencia para afrontar situaciones de emergencia en el ámbito de la vivienda, y el procedimiento para su concesión; o el Decreto-ley 2/2013, de 21 de noviembre, de Castilla y León, por el que se adoptan medidas extraordinarias de apoyo a las personas y familias afectadas por la crisis en situación de vulnerabilidad o riesgo de exclusión social [arts. 1.2, b), 3.1.d), 4 y 5], complementado por la Circular de 7 de julio 2014, relativa a la gestión de la prestación extraordinaria frente a situaciones de deuda hipotecaria establecida en dicho Decreto-ley 2/2013.

En nuestro ámbito territorial provincial, vid. la Ordenanza de 30 enero 2014 de la Diputación Provincial de León, reguladora de la prestación económica destinada a la atención de necesidades básicas de subsistencia en situaciones de urgencia social (LEG 2014\183) -Ordenanza leonesa sustancialmente igual a la dictada, con idéntico nombre, por la Diputación Provincial de Soria con fecha 2 de enero de 2014 (LEG 2014\69)-.

52 Cfr. al respecto, con carácter general, la Estrategia Nacional Integral para personas sin hogar 2015-2020 (http://www.msssi.gob.es/ssi/familiasInfancia/inclusionSocial/docs/ ENIPSH.pdf) y su análisis pormenorizado por AGÜERO ORTIZ, A., "«Sinhogarismo»: Estrategia Nacional Integral para personas sin hogar 2015-2020”, Publicaciones Jurídicas CESCO, 2015, pp. 1-14.

53 A nivel autonómico, prevén la puesta a disposición de una vivienda o alojamiento, en régimen de alquiler social, por ejemplo la Ley 3/2015, de 18 junio, de Vivienda del País Vasco; la Ley 6/2015, de 24 de marzo, de la Vivienda de la Región de Murcia [art. 63.e)]; la Orden 6/2015, de 19 de mayo, de La Rioja, que modifica la Orden 2/2013 de la Consejería de Obras Públicas, Política Local y Territorial, por la que se regula la ayuda del programa de arrendamientos especiales; o el Servicio Integral de Apoyo a Familias en Riesgo de Desahucio de Castilla y León (Decreto 58/2014, de 11 de diciembre).

Tras su crítica a las medidas jurídico-privadas adoptadas por el Gobierno y el Parlamento ante la recesión económica y la multiplicación de las ejecuciones hipotecarias y los lanzamientos, SERRANO GARCÍA, I., "Soluciones legales en materia de desahucios...", RJNot., $\mathrm{n}^{\mathrm{o}} .86-87,2013$, pp. 104, 184-185 afirma que "habiendo, como hay, más de un millón de pisos vacíos... debería haberse puesto más el acento en los alquileres sociales $y$ a través de esta figura resolver el problema de la falta de vivienda" sin tocar principios e instituciones civiles clásicas.

54 Modificada posteriormente por la Ley 9/2015 (Disposición Final 4a), fue la Ley 1/2013 la que estableció en su Disposición Adicional primera la constitución del mencionado Fondo 
2012 hasta ahora, según datos del ya citado Informe de 23 de octubre de 2015 de la Comisión de Control del Código de Buenas Prácticas ${ }^{55}-$.

Incluso se ha llegado a prever la "expropiación" forzosa de viviendas desocupadas o vacías de las que hayan sido adjudicatarios los bancos en el remate de la ejecución hipotecaria. Esta medida extrema -aun contemplada como expropiatoria no de la plena propiedad, sino del derecho de uso, quedando la entidad bancaria como nudo propietario, y aun limitada temporalmente, a efectos de "la cobertura de la necesidad de vivienda de personas en especiales circunstancias de emergencia social"- ha sido, no obstante, declarada inconstitucional respecto de la normativa andaluza ${ }^{56}$; y ha sido igualmente recurrida ante el TC en su regulación por las respectivas leyes de la vivienda de Navarra $^{57}$ y de Canarias ${ }^{58}$-con suspensión de la vigencia de los preceptos impugnados ${ }^{59}-$, por lo que, seguramente, la misma suerte vaya a correr la exorbitante declaración de interés social que a los citados efectos expropiatorios contempla la más reciente Ley de Vivienda del País Vasco de junio de $2015^{60}$.

Social de Viviendas, propiedad de las entidades de crédito, destinado a ofrecer cobertura a aquellas personas que hayan sido desalojadas de su vivienda habitual por el impago del préstamo hipotecario cuando concurran en ellas las circunstancias de vulnerabilidad previstas en la propia norma, facilitándoles el acceso a contratos de arrendamientos con rentas asumibles en función de los ingresos que perciben.

55 Con todo, se ha denunciado por no pocos autores la inadecuada e insuficiente política e infraestructura de vivienda social en España y que nuestro Fondo Social de Viviendas se revela manifiestamente escaso, al menos comparativamente con el de otros países de la Unión Europea (ZURITA, I., "Reflexiones sobre la ampliación del umbral de exclusión...", La Ley, no.8520, 2015; RODRÍGUEZ LÓPEZ, J., "Ejecuciones hipotecarias...", RDCiv., nº.3, 2014, p. 118; SÁNCHEZ HERNÁNDEZ, C., "Garantía hipotecaria, mercado y crisis...", RDPatr., $\left.\mathrm{n}^{\circ} .35,2014\right)$.

La Sentencia del Pleno del TC de 14 mayo 2015 (RTC 2015\93) estimó parcialmente el recurso de inconstitucionalidad interpuesto contra el art. 1 y la Disposición Adicional $2^{\mathrm{a}}$ del Decreto-ley 6/2013, de 9 de abril, de Medidas para asegurar el cumplimiento de la Función Social de la Vivienda, de la Junta de Andalucía [artículo 1 de dicho Decreto-ley que había dado nueva redacción a los arts. 1.3, 25 y 53.1 a) de la Ley $1 / 2010$, de 8 de marzo, reguladora del derecho a la vivienda en Andalucía].

57 Ley Foral 24/2013, de 2 de julio, de Medidas urgentes para garantizar el derecho a la vivienda en Navarra (que añade una Disposición Adicional 10 a a la Ley Foral 10/2010, de 10 mayo, del derecho a la vivienda en Navarra).

58 Ley $2 / 2014$, de 20 de junio, de modificación de la Ley 2/2003 de Vivienda de Canarias y de medidas para garantizar el derecho a la vivienda.

59 Por Providencia de 5 de noviembre de 2013, el TC admitió a trámite el recurso de inconstitucionalidad contra la antes citada Ley navarra de 2013 y suspendió la vigencia de los artículos recurridos con efectos desde 14 de octubre de 2013; suspensión cuyo mantenimiento fue acordado por el Auto del TC de 10 marzo 2014 (RTC 2014\69 AUTO).

También en cuanto a la normativa canaria, el Pleno del TC -mediante Providencia de 14 abril 2015 (JUR 2015\106011) - admitió a trámite el recurso contra la mentada Ley 2/2014 y suspendió la vigencia de tal medida expropiatoria desde el 27 de marzo de 2015.

60 Arts. 74 y 75 de la Ley 3/2015, de 18 junio, de Vivienda del País Vasco. 


\section{LA "MODA" DE LA RESOLUCIÓN ALTERNATIVA DE LOS LITIGIOS DE CONSUMO: CONSIDERACIONES INTRODUCTORIAS SOBRE SUS LUCES Y SOMBRAS A PROPÓSITO DE SU PROYECCIÓN PARTICULAR A LOS DESAHUCIOS HIPOTECARIOS}

Desde las premisas que sintéticamente hemos expuesto, es ahora momento de atender en particular -como asunto nuclear del presente estudio- a la potencial operatividad que, como complemento de las antes aludidas medidas privadas y públicas establecidas por nuestro legislador para atajar los sangrantes efectos de la crisis en los deudores hipotecarios sobreendeudados, pudieran tener ante esta coyuntura los llamados mecanismos "alternativos" de resolución de litigios.

Está de moda, ciertamente, hablar de mediación, de negociación, de arbitraje, de los sistemas $\mathrm{ADR}^{61}$ en general. Y de ello me voy a ocupar brevemente aquí -siquiera a efectos introductorios del ulterior análisis de su eventual juego en sede de lanzamientos hipotecarios-, no por "oportunismo", sino por una serie de razones objetivas que avalan la oportunidad de hacerlo.

En primer lugar, la realidad cotidiana del día a día así lo impone. No cabe negar, por ejemplo, la importancia del arbitraje como vía para resolver conflictos de alcance internacional con gran complejidad técnica, ni la contrastada y ya dilatada eficiencia de la mediación en determinados ámbitos como, señaladamente, la mediación familiar.

En segundo lugar, y conforme al signo de los tiempos, no puede desdeñarse que incluso desde las propias esferas judiciales se propicia el empleo de esos mecanismos alternativos ${ }^{62}$. $\mathrm{Y}$ he ahí las experiencias fruto de las reiteradas

En fechas aún más cercanas, también el art. 7 de la Ley 24/2015, de 29 de julio, de Medidas urgentes para afrontar la emergencia en el ámbito de la vivienda y la pobreza energética de Cataluña, regula "la cesión obligatoria de viviendas" por un periodo de tres años. Las dudas de inconstitucionalidad de esta medida han dado ya lugar a un Acuerdo adoptado por la Subcomisión de Seguimiento Normativo, Prevención y Solución de Conflictos de la Comisión Bilateral Generalidad-Estado (Resolución PRE/2682/2015, de 16 de noviembre). Y sobre esa base, algún autor ha pronosticado la más que previsible, y a su juicio fundada, impugnación ante el TC de tal cesión obligatoria de viviendas (vid. MARTÍN FABA, J.Ma., "Nuevas medidas contra el sobreendeudamiento del consumidor en la Ley 24/2015, de 29 de julio, de medidas urgentes para afrontar la emergencia en el ámbito de la vivienda y la pobreza energética de Cataluña", Publicaciones Jurídicas CESCO, 15 octubre 2015, pp. 8-9, 12-14).

61 Como es sabido, ADR es la sigla del acrónimo en idioma Inglés «Alternative Dispute Resolution», traducido al castellano como Resolución Alternativa de Conflictos.

62 Ilustrativo es al respecto el Auto del Juzgado de Primera Instancia núm. 52 de Barcelona de 26 enero 2015 (AC 2015\378), que sanciona a una de las partes por no acudir a la mediación, al entender que existe mala fe procesal, concretada en un abuso del proceso. Este abuso del proceso se constata, según dicho Auto, cuando -como en el caso del que deriva el incidente resuelto (una reclamación de cantidad ventilada en un juicio verbal en el que se reclamaba el valor de la sustitución de un vehículo al perjudicado en un accidente de tráfico)- existen compañías que mantienen litigios de escasísima cuantía 
propuestas y los planteamientos estratégicos del Ministerio de Justicia y del Consejo General del Poder Judicial ${ }^{63}$ a fin de impulsar programas de mediación vinculados a los juzgados (una suerte de mediación intrajudicial ${ }^{64}$ ), así como la confesada

(nótese que la cuantía del pleito principal era de $402,75 €$ ) y que "tienen a su alcance otros medios de realizar el valor de lo justo en cada caso concreto, mucho más barato, mucho más rápido y menos gravoso para las arcas públicas, como puede ser la mediación, cuyo uso ni siquiera intentan”. El Juzgado insiste en que ante la exigencia de ajustar el ejercicio de los derechos a las pautas de la buena fe, al tiempo que se respetan "los imperativos éticos exigidos por la conciencia social y jurídica", resulta sancionable no acudir a otros métodos, como la mediación, cuando existe una "desproporción enorme entre lo que se discute y lo que cuesta que se discuta, existiendo alternativas que no comprometen recursos públicos, que no perjudican los derechos en discusión y cuyo uso inicial evitaría muchos de los casos que hoy en día colapsan los Tribunales". Finalmente, apunta el citado Auto que "ciertamente acudir a la mediación o a otro sistema extrajudicial de resolución de conflictos no es obligatorio en España, como sí lo es en Italia para casos como el presente, pero el proceder con rectitud, bajo criterios de ética y responsabilidad social no depende de que la ley lo imponga, sino de que los ciudadanos y empresas empiecen a ser conscientes de los beneficios y perjuicios que producen en la causa pública y actúen consecuentemente".

En su elogioso comentario a dicha resolución judicial, MERELLES PÉREZ, M., "Sanción por mala fe procesal por no intentar la mediación”, La Ley, $n^{\circ} .8490,2015$ destaca que la misma representa "la punta de lanza de la apuesta definitiva por los métodos alternativos para la gestión de los conflictos frente a la contienda judicial". Dicho Auto -afirma-, sin atentar contra el art. $24 \mathrm{CE}$ o contra el principio de voluntariedad de la mediación, revela que ésta "es una eficaz herramienta para la contención del coste social que implica la puesta en funcionamiento de la maquinaria judicial. La necesidad de optimizar los recursos públicos, la proporcionalidad entre los medios utilizados y los intereses particulares, así como la necesaria concienciación social para acudir a la mediación, justifican que sea sancionable acudir al proceso judicial sin intentar la mediación, por suponer un abuso y un ejercicio antisocial del derecho".

Similares opiniones vierte el citado autor en su comentario al Auto de 11 de noviembre de 2015 dictado por el Juzgado de $1^{\text {a }}$ Instancia núm. 18 de Granada: vid. MERELLES PÉREZ, M., "La mediación como requisito previo de admisión de la demanda", La Ley, $\mathrm{n}^{\circ} .8682,15$ enero 2016.

63 A título de ejemplo, a comienzos del presente año y con ocasión del Día Europeo de la Mediación, el Ministerio de Justicia y el Consejo General del Poder Judicial han consensuado la necesaria colaboración interinstitucional para impulsar la mediación, destacando la importancia de esta vía dentro de los esfuerzos por la modernización de la Administración de Justicia (Actualidad Iustel, 22 enero 2016).

En ese marco institucional, el Consejo General del Poder Judicial otorgó el premio Calidad de la Justicia 2015, en la modalidad de "Justicia Accesible", al Tribunal Superior de Justicia de Murcia por su diseño y puesta en marcha de la Unidad de Mediación Intrajudicial de Murcia (UMIM); modelo para incorporar la mediación a la carta de servicios de la Administración de Justicia, que comenzó a funcionar de modo experimental a finales de 2013 y que constituye la primera experiencia de mediación española dentro del concepto de Oficina Judicial, integrada orgánicamente en el Servicio Común Procesal de Ordenación de Murcia (Actualidad Iustel, 29 octubre 2015).

64 Un mapa de los servicios de mediación intrajudicial existentes, acompañado de los principales hitos a nivel estatal, autonómico y de algunas de las ciudades que han destacado por aplicarla, puede verse en CALATAYUD CROS, L., "Para que la mediación 
aspiración de la Administración de Justicia a alcanzar el deseable clima de entendimiento y sintonía entre jueces y árbitros ${ }^{65}$.

En tercer lugar, las nuevas tendencias legislativas caminan en esa dirección proclive al mayor protagonismo y auge de los sistemas alternativos de resolución de conflictos. A nivel general, nos podríamos remontar, en el plano estatal ${ }^{66}$, a la Ley de Arbitraje de $2003^{67}$ y a la Ley de Mediación en Asuntos Civiles y Mercantiles de $2012^{68}$; o podríamos mencionar, en sede autonómica, y a título de ejemplo, la Ley de Mediación de Derecho Privado de Cataluña de $2009^{69}$ o la cántabra de $2011^{70}$.

Pero, ciñéndonos al terreno del consumo, a la protección del consumidor ${ }^{71}$, y sin olvidar que la citada Ley estatal 5/2012 de Mediación excluye de su ámbito de aplicación la mediación de consumo [art. 2.2.d)] -lo que ha generado no pocas

eche raíces precisa profesionales bien formados", Blog de la Universidad Internacional Valencia (VIU), 18 febrero 2016.

Para una exposición de diversas experiencias que, desde dentro de los Tribunales, se han llevado a cabo en el campo de la mediación intraprocesal, con un claro posicionamiento a favor de la misma por los beneficios que reporta, vid. LAUROBA LACASA, E./ORTUÑO MUÑOZ, P. (Coords.), "Experiencias de Tribunales en mediación", en Mediación es justicia. El impacto de la Ley 5/2012, de mediación civil y mercantil, Huygens, Barcelona, 2015.

65 A este respecto, FERNÁNDEZ ROZAS, J.C., "Riesgos de la heterodoxia en el control judicial de los laudos arbitrales", La Ley, n'.8537, 2015 da cuenta de que en los últimos encuentros celebrados con árbitros en los Tribunales de las principales sedes de arbitraje se ha propugnado la conveniencia de aunar esfuerzos entre ambos operadores jurídicos, apostando dicho autor por la necesidad de reforzar la idea de que "jueces y árbitros son aliados naturales en la resolución de controversias" (en especial, comerciales).

66 Tampoco cabe desdeñar que, en fechas aún recientes, el legislador español ha incluido la conciliación, como medio voluntario para resolver algunos conflictos evitando el pleito, en la Ley 15/2015, de 2 de julio, de la Jurisdicción Voluntaria (arts. 139-148, Disposición Final $11^{\mathrm{a}} .1$ por la que se añaden los nuevos arts. 81,82 y 83 a la Ley del Notariado y Disposición Final $12^{\mathrm{a}}$ que introduce un nuevo art. 103 bis en la LH). Vid. al respecto, GARCÍA MONTORO, L., "La conciliación en la Ley 15/2015, de 2 de julio, de la Jurisdicción Voluntaria", Publicaciones Jurídicas CESCO, 12 octubre 2015; PRATS ALBENTOSA, L., "Conflictos entre particulares, solución entre particulares: la conciliación”, Escritura Pública, nº.95, 2015, pp. 72-73; y MARTÍNEZ DE SANTOS, A., "El acto de conciliación en la nueva Ley de Jurisdicción Voluntaria", La Ley, n’.8699, 10 febrero 2016.

67 Ley 60/2003, de 23 de diciembre [en adelante, LA].

68 Ley 5/2012, de 6 de julio, de Mediación en Asuntos Civiles y Mercantiles, complementada por el Real Decreto 980/2013, de 13 de diciembre, por el que se desarrollan determinados aspectos de dicha Ley.

Ley de la Comunidad de Cataluña 15/2009, de 22 de julio, de Mediación en el ámbito del Derecho privado.

70 Ley 1/2011, de 28 de marzo, de Mediación de la Comunidad Autónoma de Cantabria.

71 Para este concreto ámbito, algunos autores abogan por utilizar el acrónimo CDR (Consumer Dispute Resolution) en lugar del genérico ADR (vid. CREUTZFELDT, N., "Alternative Dispute Resolution for Consumers", en The role od consumer ADR in the Administration of justice, München, Sellier European, 2015, p. 4). 
críticas doctrinales $^{72}-$, ha de tenerse especialmente en cuenta que, sin perjuicio de lo que luego se dirá sobre el Real Decreto 231/2008 regulador del Sistema Arbitral de Consumo, desde la propia Unión Europea se viene preconizando y alimentando la resolución alternativa de conflictos en materia de consumo $\mathrm{y}$, en particular, del consumidor de crédito.

Me refiero, en primer lugar, a la Directiva 11/2013/CE, de 21 de mayo, del Parlamento Europeo y el Consejo ${ }^{73}$; Directiva interrelacionada y complementada por el Reglamento 524/2013 ${ }^{74}$, y con precedentes en la Comunicación de la Comisión, de 4 de abril de 2001, sobre Mejora del Acceso de los Consumidores a los Mecanismos Alternativos de Solución de Litigios $^{75}$ y en la Recomendación de la Comisión, de igual fecha ${ }^{76}$, sobre los principios aplicables a los órganos extrajudiciales de resolución consensual de litigios en materia de consumo ${ }^{77}$.

A fin de implementar en nuestro Derecho interno esa Directiva 11/2013, el 17 de abril de 2015 fue aprobado en Consejo de Ministros, a propuesta del Ministerio de Sanidad, el Anteproyecto de Ley de Resolución Alternativa de Conflictos de Consumo $^{78}$-cuyo texto, caso de llegar a ver la luz ${ }^{79}$, tiene visos de consumar dicha transposición de forma poco satisfactoria, como ya se ha denunciado ${ }^{80}-$. El referido

72 Vid. p.ej. GARCÍA MÁS, F., "Ejecución de acuerdos alcanzados en mecanismos alternativos de resolución de conflictos y mecanismo de segunda oportunidad para el consumidor insolvente del artículo 242 bis de la Ley Concursal", en MENDOZA LOSANA, A.I./GARCÍA MONTORO, L., "Mecanismos alternativos de solución de conflictos: Vías eficientes y sostenibles para tutelar los derechos del consumidor", Revista CESCO, no.14, 2015, pp. 50 y 52.

73 Directiva 11/2013, relativa a la Resolución Alternativa de litigios en materia de consumo y por la que se modifica el Reglamento 2006/2004 y la Directiva 2009/22/CE.

74 Reglamento del Parlamento Europeo y del Consejo, de 21 de mayo de 2013, sobre Resolución de litigios en línea en materia de consumo y por el que se modifica el Reglamento 2006/2004 y la Directiva 2009/22/CE.

75 Comunicación 161/2001 (LCEur 2001\1432).

76 Recomendación 310/2001, de 4 abril (LCEur 2001\1331).

77 Un estudio conjunto de esos cuatro instrumentos comunitarios puede verse en VALBUENA GONZÁLEZ, F., "La Directiva europea sobre resolución alternativa de litigios (ADR) en materia de consumo", Justicia, n. $^{\circ}$, 2014, pp. 409-443. Con particular referencia a la Directiva y al Reglamento, vid. STROIE, I.R., "Alternativas a la resolución de conflictos en materia de consumo: la Directiva 2013/11/UE del Parlamento Europeo y del Consejo y el Reglamento (UE) No 524/2013 del Parlamento Europeo y del Consejo, de 21 de mayo de 2013", Revista CESCO, n.7, 2013, pp. 228-239; MARCOS FRANCISCO, D., "Consumidores, sujetos privilegiados en el nuevo paradigma de justicia civil... “, InDret, $\mathrm{n}^{\mathrm{o}} .3,2015$, pp. 13-16; y ÁLVAREZ MORENO, M ${ }^{\mathrm{a}} . \mathrm{T}$., "Aproximación a la normativa sobre mediación en litigios de consumo", $R D P, \mathrm{n}^{\circ} .100$, 2016, pp. 6-17.

78 Anteproyecto del Ministerio de Sanidad, Servicios Sociales e Igualdad (http://www.msssi. gob.es/normativa/docs/Aleyconflictosconsumo.pdf).

79 Como observa ÁLVAREZ MORENO, Ma.T., "Aproximación a la normativa sobre mediación...", $R D P, \mathrm{n}^{\mathrm{o}} .100,2016$, p. 18, n.30, este Anteproyecto de 17 de abril de 2015 "en realidad es ya un texto sin tramitación parlamentaria dado que ha concluido la legislatura".

80 Aunque no falta quien valora de forma claramente positiva el Anteproyecto (vid. AGUILAR OLIVARES, Y., "Un paso más hacia el consumidor europeo: la nueva 
Anteproyecto $^{81}$, siguiendo las pautas de la Directiva, opta por un sistema "abierto" que viene a ampliar el espectro de mecanismos extrajudiciales de resolución de conflictos -más allá de los ya existentes del arbitraje y la mediación- ${ }^{82}$, admitiendo, por lo demás ${ }^{83}$, sistemas o modelos tanto voluntarios como obligatorios ${ }^{84}$.

regulación de los ADR de consumo", Revista CESCO, n.14, 2015, pp. 36-42), son mayoría los autores que ponen en tela de juicio la bondad, acierto y rigor técnico de la regulación que contiene. En este sentido crítico se pronuncian CATALÁN CHAMORRO, $M^{\mathrm{a}}$.J., "Reflexiones críticas en torno al Anteproyecto de Ley de Resolución Alternativa de Conflictos de Consumo", Actualidad Jurídica Iberoamericana, nº.3, 2015, pp. 781-792; y GARCÍA MONTORO, L., "«Nuevo» modelo de resolución alternativa de conflictos de consumo a la luz del Anteproyecto de Ley de Resolución Alternativa de Conflictos de Consumo. Especial referencia a las posibilidades de supervivencia de la mediación y otros mecanismos tradicionales", Revista CESCO, n.14, 2015, pp. 11-27.

En particular sobre las incoherencias y los sorprendentes vacíos legales del Anteproyecto en lo que concierne a la adecuación de su regulación a la realidad de las reclamaciones formuladas por los usuarios de servicios financieros, vid. BLANCO GARCÍA, A.I., "El Anteproyecto de Ley de Resolución Alternativa de Conflictos de Consumo y su encaje en el sector financiero", Revista CESCO, $\mathrm{n}^{\circ} .15,2015$, pp. 94-101; y BARRAL VIÑALS, I., "Si no queda satisfecho... ireclame!: El futuro de la resolución de conflictos de consumo", Revista CESCO, nº.14, 2015, pp. 7-10. Por su parte, ÁLVAREZ MORENO, $M^{a}$.T., "Aproximación a la normativa sobre mediación...", $R D P, \mathrm{n}^{\mathrm{o}} .100,2016$, p. 18, tras afirmar que el Anteproyecto "deja todo indefinido" y "parafrasea constantemente a la Directiva, resolviendo muy pocas de las cuestiones planteadas por la Directiva", recuerda que conforme al citado texto prelegislativo "excepcionalmente cabe admitir en sectores con un alto nivel de conflictividad y con una adhesión limitada a las entidades de resolución de conflictos la acreditación de entidades de resolución en las que las personas decisoras estén empleadas o sean retribuidas por el empresario reclamado, siempre que no exista vínculo jerárquico ni funcional con el empresario, y que la actividad de la entidad esté claramente separada de la actividad del empresario. En realidad -añade-, esto busca acercar a determinados ámbitos contractuales como los servicios bancarios y financieros, o los seguros, para que se inicien en estos sistemas alternativos de resolución de conflictos. Aun así -concluye con realismo la autora-, generará desconfianza para el consumidor, al ver que resuelve la reclamación o propone la solución quien forma parte de la organización con la que se ha generado el conflicto tras la celebración del contrato".

81 Cfr. el Dictamen del Consejo Económico y Social de España, de 13 de mayo de 2015, sobre el Anteproyecto de Ley de Resolución Alternativa de Conflictos de Consumo.

En atención a los términos genéricos con que los sistemas alternativos de resolución son definidos en el Anteproyecto y en la Directiva (vid. igualmente art. 131-3 Código de Consumo de Cataluña), habría que reflexionar acerca de si quedaría amparado bajo esa nueva normativa, y dentro de los posibles mecanismos venideros, por ejemplo el recurso a la figura del Ombudsman -siguiendo el consolidado ejemplo del Reino Unido-.

Incluso sería de interés ahondar, a fin de determinar su eventual consideración o no como sistema ADR, en el estudio del ámbito y repercusión de los servicios de reclamaciones previstos en la Orden ECC/2502/2012, de 16 de noviembre, que regula el procedimiento de presentación de reclamaciones ante los servicios de reclamaciones del Banco de España, la Comisión Nacional del Mercado de Valores y la Dirección General de Seguros y Fondos de Pensiones.

83 Asimismo se da cabida, dentro de la inminente normativa sobre resolución alternativa de conflictos de consumo, a procedimientos con un resultado que puede ser tanto vinculante como no vinculante para las partes (art. 6 y concordantes del Anteproyecto). 
Por otro lado, y en segundo lugar, ha de tenerse también en buena consideración la Directiva 17/2014, de 4 de febrero, sobre los Contratos de Crédito celebrados con los Consumidores para Bienes Inmuebles de Uso Residencial; Directiva -cuya incorporación a nuestro ordenamiento debiera haber visto la luz antes del 21 de marzo de 2016 (art. 42)- que contiene alusiones expresas a las vías extrajudiciales de resolución, tanto en su Considerando $77^{\circ}$ como en su art. 39, de modo particular para los conflictos referentes al consumidor de crédito hipotecario.

Pues bien, sin perjuicio de lo dicho, y aunque no pretendo aquí plantear una "enmienda a la totalidad" o ir en contra de la realidad y la fuerza de los hechos ni menospreciar en absoluto el papel de estos mecanismos alternativos a la vía judicial, sí quisiera dejar constancia de que los mismos presentan luces y sombras, bondades e inconvenientes, y crean algunas disfunciones o paradojas que se agudizan, de forma especialmente acusada, en su proyección particular a la órbita de los desahucios hipotecarios de la vivienda habitual.

Enseguida detallaré esos flecos al hilo del análisis del respectivo juego del arbitraje de consumo y de la mediación en ese concreto asunto y de si estamos, o no tanto, ante instrumentos jurídicamente viables y económicamente eficientes para tutelar al deudor hipotecario. Pero en línea de principio, creo que, aunque bien está que hoy en día nos encontremos inmersos en el mundo de la "negociación", hemos de ser cautelosos al respecto: preservar también la llamada «cultura del pago» ${ }^{85}$ y ser conscientes de que la "desjudicialización" no constituye la panacea ${ }^{86}$. Siendo realistas, y como de inmediato se verá, la eficacia de la mediación y, sobre todo, del sistema arbitral de consumo como vehículos para poner freno a los desahucios hipotecarios genera más escepticismo que otra cosa (o, a lo sumo, un optimismo moderado).

En definitiva, habría que «repensar» sosegadamente si, acaso, no sería preferible y más útil que fomentar, incentivar, alentar, propiciar $-\mathrm{o}$ incluso imponer- fórmulas extrajudiciales de resolución de litigios, destinar los esfuerzos e invertir más y mejor en la Administración de Justicia ${ }^{87}$. Pero eso, efectivamente, es más caro.

84 El Anteproyecto garantiza a los consumidores el acceso a entidades de resolución alternativa de conflictos de consumo, que tras acreditar los requisitos de calidad exigidos de forma armonizada, hayan sido notificadas a la Comisión Europea para su inclusión en el listado único de entidades notificadas por los diferentes Estados miembros (arts. 17-21). El recurso a estas entidades acreditadas (de naturaleza pública o privada) y a sus procedimientos se configura en el Anteproyecto, en términos generales, como voluntario para las partes, pero asimismo se permite, de forma expresa, que una norma establezca la obligatoriedad de recurrir a procedimientos gestionados por ese tipo de entidades, sin que se pueda impedir en este caso el acceso al sistema judicial.

85 En expresión de, entre otros, VIGUER SOLER, P.L., "Análisis crítico del RDL 1/2015..., La Ley, n'.8592, 2015.

86 No faltan, pese a todo, quienes parecen vislumbrar en los sistemas extrajudiciales una especie de varita mágica para la resolución de los conflictos y llegan a hablar, en concreto, del "milagro de la mediación" (Antonio SÁNCHEZ-PEDREÑO, presidente del Centro de Mediación Empresarial de la Cámara de Comercio de Madrid, $A B C, 30$ octubre 2015).

87 Vid. en esta línea, CALVO SÁNCHEZ, Ma.C., "Prólogo", en MARTíN DIZ, F., La mediación: sistema complementario de administración de justicia, Madrid, CGPJ, 2010, p. 14. 


\section{EL (EVENTUAL) PAPEL DEL ARBITRAJE DE CONSUMO ANTE EL DESAHUCIO DE LA VIVIENDA HABITUAL: SU LIMITADÍSIMA VIRTUALIDAD TÉCNICA Y PRÁCTICA}

A fin de dilucidar el papel que pueda desempeñar el arbitraje de consumo en el terreno de los lanzamientos hipotecarios, hemos de preguntarnos si en este concreto ámbito es (o no) posible, viable y eficiente tal mecanismo extrajudicial de resolución de conflictos.

\section{Caracterización del sistema arbitral de consumo y dificultades jurídicas para su operatividad en el ámbito de los lanzamientos hipotecarios}

Empezando con la cuestión netamente jurídica y normas en mano, ¿es jurídicamente admisible aquí el arbitraje de consumo? O, por el contrario, ¿hay impedimentos legales que se deriven del Real Decreto 231/2008 ${ }^{88}$, regulador del Sistema Arbitral de Consumo (o, supletoriamente ${ }^{89}$, de la Ley de Arbitraje de 23 de diciembre de 2003)?

En una caracterización, muy esquemática, de las notas del arbitraje de consumo que ahora importan, conviene recordar que estamos ante un método extrajudicial de naturaleza heterocompositiva -es un tercero, el árbitro o colegio arbitral, quien resuelve la controversia-; con un origen esencialmente voluntario ${ }^{90}$-fundado en la autonomía de la voluntad de las partes-; y que, por regla general, salvo acuerdo expreso en contra, los laudos arbitrales de consumo se dictan en equidad ${ }^{91}$.

\subsection{Exigencias subjetivas del arbitraje de consumo y arbitrabilidad del desahucio sobre la vivienda habitual}

Partiendo de esos rasgos elementales del arbitraje institucional de consumo, y centrados en primer lugar en sus condicionamientos subjetivos, resulta claro que no habría ningún obstáculo, desde este punto de vista de las partes o sujetos "litigantes" implicados, para que el conflicto vinculado a un desahucio hipotecario sobre la vivienda habitual tuviese cabida dentro del sistema arbitral de consumo.

\footnotetext{
88 RD 231/2008, de 15 de febrero.

89 Vid. art. 1.3 y Disposición adicional única de la LA 60/2003 y art. 3.1 RD 231/2008. Sobre dicha supletoriedad, vid. por todos ÁLVAREZ SÁNCHEZ DE MOVELLÁN, P., "Procedimiento arbitral en la Ley de Arbitraje 60/2003 y supletoriedad en el arbitraje de consumo", en Protección de los consumidores e inversores, arbitraje y proceso, Madrid, Reus, 2009.

90 Vid. la Exposición de Motivos y el art. 24.1 del RD 231/2008.

91 Vid. la Exposición de Motivos y el art. 33.1 del RD 231/2008.
} 
Como es sabido, éste reclama que el asunto litigioso sea entre un consumidor o usuario $^{92}$ y un empresario o profesional (según exigen el art. 1.2 RD 231/2008 y el art. 57.1 TR de la LGDCU de $2007^{93}$ ). Y en el caso que nos ocupa, no se pone en entredicho la cualidad de consumidor (conforme al art. 3 TR de la LGDCU) del reclamante - del deudor hipotecario-, ni la condición de profesional o empresario (con arreglo al art. 4 TR de la LGDCU) que ostenta la entidad bancaria prestamista $^{94}$.

\subsection{Ejecución de la garantía hipotecaria y materias objetivamente sustraídas del procedimiento arbitral de consumo.}

Veamos ahora si existe algún escollo por razón del ámbito objetivo de aplicación del arbitraje y del de consumo en particular.

El Real Decreto 231/2008 regulador del Sistema Arbitral de Consumo recoge, en el art. 2.2, una serie de materias que no pueden ser objeto de arbitraje de consumo ${ }^{95}$

92 A efectos de la legitimación activa en el arbitraje de consumo, formulan objeciones a la rigidez y el carácter demasiado restrictivo del concepto de consumidor, p.ej. DÍAZ ALABART, S., "El concepto de consumidor en el arbitraje de consumo", en El arbitraje de consumo: una nueva dimensión del arbitraje de derecho privado, Valencia, Tirant lo Blanch, 2004, pp. 52 y ss.; CASADO CERVIÑO, A., "El arbitraje de consumo", en Comentarios a la Ley de Arbitraje, coord. por MARTÍN MUÑOZ, A./HIERRO ANIBARRO, S., Madrid, Marcial Pons, 2006, pp. 914-915; y MARÍN LÓPEZ, M.J., "Presente y futuro del arbitraje de consumo: cuarenta y tres cuestiones controvertidas", Publicaciones Jurídicas CESCO, 2006, pp. 5-6.

93 Texto Refundido de la Ley General para la Defensa de los Consumidores y Usuarios y otras leyes complementarias, aprobado por Real Decreto Legislativo 1/2007, de 16 de noviembre.

94 Interesa traer a colación que, en materia de relaciones consumidor-empresa fundadas en clausulados no negociados individualmente, el art. 90.1 TR de la LGDCU reputa abusivas (y, por tanto, se tienen por no puestas) las cláusulas que establezcan "la sumisión a arbitrajes distintos del arbitraje de consumo, salvo que se trate de órganos de arbitraje institucionales creados por normas legales para un sector o un supuesto específico".

En cambio, en sede de arbitraje común, la vigente Ley de Arbitraje de 2003 -a diferencia de su predecesora de 1988 (Ley 36/1988, de 5 diciembre)- ha prescindido de enumerar, ni en términos exhaustivos ni siquiera ad exemplum, un elenco de materias no susceptibles de arbitraje (con lo que va de suyo que no hay tampoco aquí exclusión explícita de los desahucios hipotecarios). Como explica la Exposición de Motivos de dicha LA, "el artículo 2 regula las materias objeto de arbitraje sobre la base del criterio de la libre disposición, como hacía la Ley 36/1988. Sin embargo, se reputa innecesario que esta Ley contenga ningún elenco, siquiera ejemplificativo, de materias que no son de libre disposición. Basta con establecer que la arbitrabilidad de una controversia coincide con la disponibilidad de su objeto para las partes. En principio, son cuestiones arbitrables las cuestiones disponibles. Es concebible que por razones de política jurídica haya o pueda haber cuestiones que sean disponibles para las partes y respecto de las que se quiera excluir o limitar su carácter arbitrable. Pero ello excede del ámbito de una regulación general del arbitraje y puede ser objeto, en su caso, de disposiciones específicas en otros textos legales". 
-los conflictos que versen sobre lesiones o muertes ${ }^{96}$ o donde existan indicios racionales de delito-; y en esa lista de materias excluidas expressis verbis, coincidentes con la que enumera el art. 57.1 TR de la LGDCU, no figura el desahucio de la vivienda habitual.

Sin embargo, el citado Real Decreto de Arbitraje de Consumo -como igualmente la $\mathrm{LA}^{97}$ - sí establece de forma diáfana, en su art. 2.1, que solo son susceptibles de arbitraje las "materias de libre disposición" $"$ " Y es en esta cláusula abierta (o concepto jurídico indeterminado, si se quiere $)^{99}$ donde, acaso, radique uno de los ejes de la discusión acerca de la arbitrabilidad o no sobre los lanzamientos hipotecarios.

No es momento ahora para enfrascarse en las profundas disquisiciones dogmáticas acerca de la noción de "libre disposición", sobre la cual existen no pocas disputas doctrinales $^{100}$ que, en gran medida, se han suscitado en sede de arrendamientos urbanos. Y es también en este ámbito donde se cuenta con una nutridísima jurisprudencia menor que, con gran disparidad de criterios, se pronuncia acerca de si es o no materia disponible -y, por ende, arbitrable o no- el desahucio arrendaticio, la resolución del arrendamiento de vivienda (a menudo, por impago de rentas) y el desalojo del inquilino.

De forma muy resumida, y en lo que valga el paralelismo o la analogía, conviene recordar que algunos tribunales consideran que la resolución del contrato por incumplimiento del arrendatario y el lanzamiento de éste son cuestiones reservadas a

96 En sentido crítico con la exclusión de tales materias de la vía arbitral de consumo, vid. entre otros autores DÍEZ GARCÍA, H., "Admisión e inadmisión a trámite de solicitudes de arbitraje de consumo", Aranzadi Civil [en adelante AC], n.14, 2007, pp. 37-38.

97 Dispone el art. 2.1 LA de 2003 que "son susceptibles de arbitraje las controversias sobre materias de libre disposición conforme a derecho".

98 A tenor del art. 2.1 RD 231/2008, "únicamente podrán ser objeto de arbitraje de consumo los conflictos a que se refiere el artículo 1.2 que versen sobre materias de libre disposición de las partes conforme a derecho".

99 Como señala la SAP Madrid de 20 octubre 2010 (AC 2010\1807), "si bien en la Ley de Arbitraje se establece una cláusula abierta sobre las cuestiones susceptibles de arbitraje, no se ha llevado a cabo una tipificación del elemento objetivo del arbitraje, por lo que dicha norma en blanco ha de completarse atendiendo a las materias que son susceptibles de disposición por las partes".

100 Aunque no faltan opiniones discrepantes (TASENDE CALVO, J.J., "El arbitraje de consumo: Objeto y exclusiones: El arbitraje de arrendamientos urbanos y el de transporte", Actualidad Civil [en adelante Act.Civ.], no.4, 1997, p. 953), domina la tesis de que no cabe confundir ni identificar necesariamente las materias indisponibles con las materias regidas por normas imperativas (SSTS 21 de marzo de 1985 [RJ 1985, 1193] y 30 noviembre 2001 [RJ 2001, 9855]), pues, en otro caso, la defensa del consumidor por la vía del arbitraje -o la del arrendatario de vivienda- resultaría impensable, dada la naturaleza de Derecho necesario de muchas de las normas que le dispensan protección (vid. por todos, DÍEZ GARCÍA, H., “Admisión...”, AC, no.14, 2007, p. 19; y HERNÁNDEZ-GIL ÁLVAREZ-CIENFUEGOS, A., "Comentario a los arts. 1 a 8 de la Ley 60/2003", en Comentarios a la Ley de Arbitraje, coord. por MARTÍN MUÑOZ, A./HIERRO ANIBARRO, S., Madrid, Marcial Pons, 2006, pp. 151-152). 
la jurisdicción, a la competencia judicial y, por tanto, no susceptibles de arbitraje ${ }^{101}$. Otras muchas resoluciones, por el contrario, entienden que todas las cuestiones arrendaticias, incluido el desahucio, son arbitrables ${ }^{102}$. Pero, dentro de esta corriente, y respecto del desahucio en el arrendamiento de vivienda, la tendencia abrumadoramente dominante es que ha de tratarse de arbitraje de Derecho ${ }^{103}$-la regla en el arbitraje común u ordinario (art. 34.1 LA)-, quedando vetado el arbitraje de equidad ${ }^{104}$. Y de ahí que tanto la jurisprudencia mayoritaria como autorizadas voces en el tema ${ }^{105}$ excluyan del ámbito del arbitraje de consumo los desahucios arrendaticios ${ }^{106}$.

Pues bien, extrapolando lo dicho, mutatis mutandis, al tema objeto de nuestro estudio, creo que cuando del desahucio hipotecario se trata, propiamente no hay "conflicto", no hay "contienda" o materia arbitrable: el deudor ha impagado (porque no puede o no quiere pagar) y la entidad bancaria acreedora simplemente procede a ejecutar la garantía; ejecución de la garantía hipotecaria que, entiendo, está sustraída del ámbito del sistema

101 Contrarios a la admisión del llamado desahucio arrendaticio arbitral se muestran los Autos de la AP de Madrid de 14 octubre 2010 (JUR 2011/17842), 10 enero 2012 (JUR 2012/58158) y 9 enero 2013 (JUR 2013/68373).

En la doctrina, sostiene la imposibilidad de someter a arbitraje alguno las cuestiones relativas a la resolución del contrato de arrendamiento y, en consecuencia, el desahucio, YÚFERA SALES, P., Arrendamientos urbanos. Análisis práctico de la normativa arrendaticia aplicable, sistematizada por conceptos, Barcelona, Bosch, 2006, p. 581.

102 Vid. p.ej. la S. TSJ Madrid (Sala de lo Civil y Penal) de 11 noviembre 2014 (JUR 2015 $\backslash 11163$ ) y los Autos de la AP de Madrid 27 octubre 2010 (AC 2010/2056), 17 noviembre 2010 (AC 2010/2163), 3 mayo 2011 (AC 2011/1207), 26 marzo 2012 (JUR 2012/167140) y 24 enero 2013 (JUR 2013/86694).

Ampliamente en la doctrina sobre las razones en favor de la arbitrabilidad, en términos generales, de la materia arrendaticia urbana, incluido el desahucio, vid. ORDÁS ALONSO, M., "Comentario al artículo 4.5 de la LAU", en Comentarios a la Ley de Arrendamientos Urbanos, coord. por R. BERCOVITZ RODRÍGUEZ-CANO, Cizur Menor, Aranzadi, 2013, pp. 140-146.

103 Vid. Auto de la AP de Madrid de 20 julio 2010 (JUR 2010\309769).

104 A título de ejemplo, vid. los Autos de la AP Madrid de 2 noviembre 2011 (AC 2011\1602), 8 febrero 2011 (AC 2011 829 ), 11 abril 2011 (AC 2011\1082), 27 julio 2011 (JUR 2011\338057) y 20 octubre 2010 (JUR 2011\17098); o el Auto de la AP de Lugo de 10 junio 2008 (JUR 2008\338575).

En la doctrina, rechazan la posibilidad del arbitraje de equidad para el desahucio del inquilino ORDÁS ALONSO, M., "Comentario al artículo 4.5 de la LAU", en Comentarios..., 2013, pp. 147-150; GÁZQUEZ SERRANO, L, "Las cláusulas arbitrales en los contratos de arrendamientos urbanos", Act.Civ., n.21-22, 2012, p. 7; y MORALES MUÑOZ, E., "Arbitraje. Concepto. Naturaleza. Fundamento. Clases. Arbitrajes especiales", Act.Civ., no.17, 2007, p. 8.

105 Vid. por todos, ORDÁS ALONSO, M., "Comentario al artículo 4.5 de la LAU”, en Comentarios..., 2013, pp. 151-152; y BUSTO LAGO, J.M., "El control judicial del laudo arbitral de consumo en el procedimiento de ejecución", $A C-M, \mathrm{n}^{\mathrm{o}} .7,2010$.

106 Concretamente, en el supuesto -menos común en la práctica del mercado inmobiliario de viviendas de alquiler en España, que es mayoritariamente de particulares- de que el contrato de arrendamiento sea entre un arrendatario particular y un arrendador en el que concurra la condición de empresario o profesional. 
arbitral de consumo ${ }^{107}$. No parece posible ejecutar la garantía en un procedimiento arbitral, porque cualquier discusión que no tenga cabida en el art. 695 de la LEC es irrelevante para la realización de la hipoteca ${ }^{108}$.

107 También BARRAL VIÑALS, I., "Si no queda satisfecho...", Revista CESCO, no.14, 2015 , p. 6 considera que el arbitraje de consumo "excluye los procedimientos de ejecución y, por tanto, la ejecución hipotecaria".

108 El artículo 695 de la LEC 1/2000 -en su vigente redacción tras las sucesivas reformas del precepto por las Leyes 1/2013, 8/2013 y 9/2015- reza así:

"1. En los procedimientos a que se refiere este Capítulo sólo se admitirá la oposición del ejecutado cuando se funde en las siguientes causas:

$1^{\text {a }}$. Extinción de la garantía o de la obligación garantizada, siempre que se presente certificación del Registro expresiva de la cancelación de la hipoteca o, en su caso, de la prenda sin desplazamiento, o escritura pública de carta de pago o de cancelación de la garantía.

$2^{\text {a }}$. Error en la determinación de la cantidad exigible, cuando la deuda garantizada sea el saldo que arroje el cierre de una cuenta entre ejecutante y ejecutado. El ejecutado deberá acompañar su ejemplar de la libreta en la que consten los asientos de la cuenta y sólo se admitirá la oposición cuando el saldo que arroje dicha libreta sea distinto del que resulte de la presentada por el ejecutante.

No será necesario acompañar libreta cuando el procedimiento se refiera al saldo resultante del cierre de cuentas corrientes u operaciones similares derivadas de contratos mercantiles otorgados por entidades de crédito, ahorro o financiación en los que se hubiere convenido que la cantidad exigible en caso de ejecución será la especificada en certificación expedida por la entidad acreedora, pero el ejecutado deberá expresar con la debida precisión los puntos en que discrepe de la liquidación efectuada por la entidad.

$3^{\text {a }}$. En caso de ejecución de bienes muebles hipotecados o sobre los que se haya constituido prenda sin desplazamiento, la sujeción de dichos bienes a otra prenda, hipoteca mobiliaria o inmobiliaria o embargo inscritos con anterioridad al gravamen que motive el procedimiento, lo que habrá de acreditarse mediante la correspondiente certificación registral.

$4^{\text {a }}$. El carácter abusivo de una cláusula contractual que constituya el fundamento de la ejecución o que hubiese determinado la cantidad exigible.

2. Formulada la oposición a la que se refiere el apartado anterior, el Secretario judicial suspenderá la ejecución y convocará a las partes a una comparecencia ante el Tribunal que hubiera dictado la orden general de ejecución, debiendo mediar quince días desde la citación, comparecencia en la que el Tribunal oirá a las partes, admitirá los documentos que se presenten y acordará en forma de auto lo que estime procedente dentro del segundo día.

3. El auto que estime la oposición basada en las causas $1^{\mathrm{a}}$ y $3^{\mathrm{a}}$ del apartado 1 de este artículo mandará sobreseer la ejecución; el que estime la oposición basada en la causa $2^{\mathrm{a}}$ fijará la cantidad por la que haya de seguirse la ejecución.

De estimarse la causa $4^{\mathrm{a}}$, se acordará el sobreseimiento de la ejecución cuando la cláusula contractual fundamente la ejecución. En otro caso, se continuará la ejecución con la inaplicación de la cláusula abusiva.

4. Contra el auto que ordene el sobreseimiento de la ejecución, la inaplicación de una cláusula abusiva o la desestimación de la oposición por la causa prevista en el apartado $1.4^{\circ}$ anterior, podrá interponerse recurso de apelación.

Fuera de estos casos, los autos que decidan la oposición a que se refiere este artículo no serán susceptibles de recurso alguno y sus efectos se circunscribirán exclusivamente al proceso de ejecución en que se dicten". 


\section{La realidad de las cosas más allá de la letra de la ley}

Con todo, como la cuestión técnico-jurídica podría ser polémica, aun aceptando in abstracto que el desahucio hipotecario fuese considerado materia arbitrable, aun en la hipótesis - poco verosímil- de que algún presidente de Junta Arbitral de Consumo admitiera a trámite una solicitud de arbitraje acerca del lanzamiento de un deudor hipotecario $^{109}$, ¿por qué no hay, ni se espera, un gran éxito real del arbitraje de consumo en este campo?

A mi juicio, es crucial atender a la realidad de las cosas, más allá del Derecho; y unos cuantos datos fácticos pueden iluminar el panorama, siquiera interpretados $a$ sensu contrario.

\subsection{Datos de la praxis judicial y arbitral. La desconfianza del sector bancario frente al arbitraje de consumo}

Rastreando exhaustivamente la jurisprudencia, no se encuentra ni un solo asunto en que, al hilo de la anulación de laudos de consumo - por haber resuelto sobre materia no arbitrable [ex art. 41.e) $\mathrm{LA}^{110}$-, el problema haya versado sobre un laudo que se hubiese pronunciado acerca del desahucio del deudor hipotecario de su vivienda habitual.

Tampoco cabe localizar ninguna resolución judicial sobre ese particular, con ocasión de la ejecución forzosa de laudos arbitrales de consumo ${ }^{111}$ : ni aceptando el despacho de la ejecución, ni denegándola por estimarse que el objeto del laudo -el desahucio hipotecario- era cuestión situada extramuros del procedimiento arbitral ${ }^{12}$.

109 Recuérdese que una de las "Causas de inadmisión de solicitudes de arbitraje de consumo" por el Presidente de la Junta Arbitral (art. 35.1 RD 231/2008) es que el asunto verse sobre materias no susceptibles de arbitraje de consumo, ex art. 2.

110 Dispone este art. 41 que "1. El laudo sólo podrá ser anulado cuando la parte que solicita la anulación alegue y pruebe:... e) Que los árbitros han resuelto sobre cuestiones no susceptibles de arbitraje. f) Que el laudo es contrario al orden público". Vid. sobre el tema, por todos, SAMANES ARA, C., "La acción de anulación contra el laudo arbitral de consumo a la luz de la Ley 60/2003, de 23 de diciembre, de arbitraje", en Curso de mediación y arbitraje. Nuevos retos del arbitraje de consumo, Dirección General de Consumo del Gobierno de Aragón, 2005, pp. 29 y ss.; y ÁLVAREZ SÁNCHEZ DE MOVELLÁN, P., "Algunas cuestiones sobre la anulación judicial del laudo en la Ley 60/2003, de Arbitraje”, La Ley, nº.4, 2004, pp. 1959-1970.

111 Un magnífico estudio de la ejecución forzosa de los laudos arbitrales de consumo (arts. 44-45 LA) puede verse en BUSTO LAGO, J.M., "El control judicial del laudo arbitral de consumo en el procedimiento de ejecución", $A C-M, \mathrm{n}^{\mathrm{o}} .7,2010$.

112 A este respecto, no cabe ocultar que los laudos de consumo son cumplidos voluntariamente en un porcentaje muy elevado (alrededor del 98 por ciento), por lo que el dato de que no haya habido que recurrir a la vía judicial para dirimir la procedencia de ejecutar o no forzosamente un hipotético laudo sobre un desahucio hipotecario, aunque sea ilustrativo no es del todo determinante. 
Amén de no contarse en la praxis judicial con ninguna muestra de la operatividad del arbitraje de consumo en este concreto tema, también quiero señalar, siquiera a título personal y por razón de mi experiencia práctica en la Junta Arbitral de Consumo de León, que nunca se ha conocido aquí asunto alguno -ni aun en los peores años de la crisis- de solicitud de arbitraje sobre la procedencia del lanzamiento o no de su vivienda a un deudor hipotecario ${ }^{113}$.

Esto enlaza con la palmaria reticencia de las entidades bancarias a adherirse al Sistema Arbitral de Consumo -y con el manifiesto fracaso de este sistema en ciertos ámbitos del consumo como, precisamente, y entre algunos otros ${ }^{114}$, en el bancario o financiero-. El recelo, desconfianza y cierta aversión de este sector frente al arbitraje de consumo ${ }^{115}$ procede, entre cosas, por un lado, del temor a una multiplicación o boom de reclamaciones, al tratarse de un sistema gratuito (art. 41.1. in fine $\mathrm{RD} 231 / 2008)^{116}$, $\mathrm{y}$, por otro lado, de la percepción por los bancos de la escasa profesionalización del arbitraje de consumo, particularmente porque aquí el laudo, dictado como regla en equidad, aunque ha de ser motivado en todo $\operatorname{caso}^{117}$, no ha de estar necesariamente fundado en Derecho ${ }^{118}$.

113 Es más, fuera ya del caso particular de los desahucios, solamente hemos arbitrado un asunto donde se planteó por el consumidor una reclamación contra una entidad financiera -solicitando a ésta la restitución de cantidades indebidamente percibidas- y dicha entidad, no adherida al sistema arbitral de consumo, aceptó el arbitraje para ese concreto litigio -si bien es cierto que tal banco había ya recibido previamente una resolución parcialmente desfavorable del Servicio de Reclamaciones del Banco de España, por lo que quizás temiera una probable sentencia condenatoria en un eventual procedimiento judicial entablado por su cliente-. Cfr. DÍEZ GARCÍA, H., “Admisión...”, AC, nº.14, 2007, p. 19, n.21.

114 Por ejemplo, en los sectores de las compañías aéreas, las aseguradoras y algunas grandes superficies; ámbitos, sumados al bancario, respecto de los cuales afirmaba en 2004 FLORENSA I TOMÁS, C.E., "Prólogo", en El arbitraje de consumo: una nueva dimensión del arbitraje de derecho privado, Valencia, Tirant lo Blanch, 2004, p. 22 que "la plena integración de estos sectores en el sistema arbitral de consumo es una auténtica asignatura pendiente que hay que aprobar cuanto antes". Transcurridos más de diez años desde ese optimista y casi utópico deseo, la asignatura pendiente sigue suspensa.

115 Vid. DÍEZ GARCÍA, H., “Admisión...”, AC, nº.14, 2007, p. 19.

También BLANCO GARCÍA, A.I., "El Anteproyecto de Ley de Resolución Alternativa...", Revista CESCO, no.15, 2015, p. 97 pone en evidencia que "en el ámbito bancario y financiero ha quedado patente la ausencia de una verdadera "cultura arbitral», motivada por las reticencias de las instituciones crediticias a someter cualquier controversia a arbitraje".

116 De ahí que, estratégicamente, las entidades bancarias prefieran asumir el riesgo de un eventual proceso judicial, aunque sea más costoso, porque saben a ciencia cierta que un gran porcentaje de sus clientes no acudirá a los tribunales.

117 Todos los laudos de consumo, también los de equidad, deben estar motivados (arts. 33.2 y 48.1 RD 231/2008) -a diferencia de lo que sucedía bajo el primitivo RD 636/1993, donde sólo se exigía motivación para el arbitraje de derecho-.

118 Repárese, sin embargo, que el hecho de que el arbitraje sea en equidad no impide a los árbitros fundar sus decisiones en normas de Derecho positivo, como de hecho sucede con frecuencia en los laudos dictados en el arbitraje de consumo (MARÍN LÓPEZ, M.J., "Presente y futuro del arbitraje de consumo...", Revista CESCO, 2006, pp. 54-55). Y en 


\subsection{El cálculo (jurídico-económico) de riesgos y costes como desincentivo para la adhesión de las entidades prestamistas al sistema arbitral de consumo}

Con todo, y en íntima relación con lo anteriormente apuntado, creo que el fracaso generalizado del sistema arbitral de consumo en el sector bancario y la nula operatividad práctica que ha tenido y tiene en el caso particular de los desahucios hipotecarios deriva, en gran medida, de la misma esencia voluntaria del arbitraje ${ }^{119}$. Las partes se someten al mismo libre y voluntariamente ${ }^{120}$; y a tal efecto, para sopesar si les conviene o no hacerlo, van a efectuar un cálculo de riesgos y de costes.

Ese cálculo es, inevitablemente, un cálculo comparativo con los riesgos y costes de un proceso judicial. Y en ese cálculo son elementos decisivos la situación jurídica y la situación económica de cada una de las partes.

Aplicado lo anterior al supuesto de los desahucios hipotecarios, tenemos que:

(i)- Por un lado, ante el impago del deudor hipotecario y la pretensión del acreedor de ejecutar su garantía, la situación normativa, el Derecho formalmente aplicable, es claramente favorable a la entidad bancaria. El banco, que en el seno del procedimiento judicial de ejecución hipotecaria tendría las de ganar ${ }^{121}$, difícilmente va a aceptar someterse a un arbitraje, y menos aún, "arriesgarse" a un laudo en equidad.

cualquier caso, la resolución del conflicto por el árbitro conforme a su leal saber y entender no equivale a arbitrariedad (STC 43/1988, de 16 de marzo [RTC 1988, 43]) ni a discrecionalidad absoluta por parte de los árbitros (ESPLUGUES MOTA, C., "Comentario al art. 34", en Comentarios a la Ley de Arbitraje, coord. por S. BARONA VILAR, Madrid, Civitas, 2004, p. 1117; MARCOS FRANCISCO, D., "El arbitraje de consumo como medio extrajudicial de resolución de conflictos en la normativa española", Revista de Derecho Universidad Católica del Norte, $\mathrm{n}^{\circ} .1,2011$, p. 256).

Por otra parte, y respecto a la aptitud profesional que han de tener los árbitros en el arbitraje de consumo, conviene recordar que "los árbitros acreditados a propuesta de la Administración deberán ser licenciados en derecho, ya resuelvan en equidad o en derecho" (art. 17 RD 231/2008) y que "en los arbitrajes que deban decidirse en derecho, los árbitros designados entre los acreditados a propuesta de las asociaciones de consumidores y usuarios y de las organizaciones empresariales o profesionales, deberán ser licenciados en derecho" (art. 21.1 RD 231/2008).

119 Vid. en igual sentido DÍEZ GARCÍA, H., “Admisión...”, AC, nº.14, 2007, p. 19.

${ }^{120} \mathrm{Y}$ ello, obviamente, presupone un convenio arbitral o la adhesión al sistema arbitral de consumo por parte de la empresa.

121 Como señala DÍEZ GARCÍA, H., "Igualdad de armas y tutela judicial...", $D P y C, \mathrm{n}^{\circ} .28$, 2014, p. 230, "resulta algo obvio que, en el proceso de ejecución hipotecaria, el acreedor hipotecario goza, frente al ejecutado, de una superioridad palmaria o de una posición privilegiada derivada de la fuerza ejecutiva de su título, por lo que el ejecutado siempre parte de una situación de desventaja”. Sobre esa situación procesal de superioridad de la entidad financiera crediticia, vid. ampliamente FERNÁNDEZ SEIJO, J.M., La defensa de los consumidores en las ejecuciones hipotecarias, 2013, pp. 179 y ss. 
(ii)- Por otro lado, y fundamental, las cantidades económicas que los bancos se juegan en estos asuntos son netamente superiores a los costes económicos de un pleito judicial ordinario, pues es obvio que en el campo de los desahucios hipotecarios la cuantía de la controversia no puede ser calificada como bagatela.

En definitiva, pues, aunque el RD 231/2008 realza, a bombo y platillo, su aspiración de incrementar la confianza en el arbitraje de consumo, no solo de los consumidores, sino también de las empresas ${ }^{122}$; y aunque al comienzo de la vigencia de la norma, algunos autores llegaran a augurar un extraordinario éxito a este sistema ${ }^{123}$, lo cierto es que, en España, el tiempo ha demostrado que no ha tenido tanta eficiencia y virtualidad práctica como era esperable ${ }^{124}$, al menos en algunos sectores como el de los servicios bancarios y crediticios.

\section{Fomento del arbitraje de consumo y presunción de sumisión de las entidades crediticias al arbitraje: entre legislación simbólica y normativa de dudosa constitucionalidad en el Derecho catalán}

Por todas las razones que con anterioridad se han indicado, y poniendo ahora una nota de Derecho autonómico, creo que es legislación simbólica más que otra cosa, que son un "brindis al sol", normas como la del art. 133-4, párr. 5 del Código de Consumo de Cataluña de $2010^{125}$ cuando habla de "fomentar y estimular" a las empresas que otorgan créditos o préstamos hipotecarios sobre la vivienda para que se adhieran al arbitraje de consumo ${ }^{126}$. Y es que he ahí el quid de la cuestión: cómo estimularlas realmente, cómo diseñar in concreto un sistema arbitral atractivo que, con plenas garantías de competencia, imparcialidad y profesionalidad, lograra

122 Según puede leerse en su propio Preámbulo, este Reglamento pretende "reforzar la confianza en él de empresas o profesionales y consumidores o usuarios, asegurando el recurso a este sistema extrajudicial de resolución de conflictos que, como tal, es de carácter voluntario".

123 Vid. FLORENSA I TOMÁS, C.E., "Prólogo", en El arbitraje de consumo..., 2004, pp. $15-18$

124 CARRASCO PERERA, Á., "Presentación", en MENDOZA LOSANA, A.I./GARCÍA MONTORO, L., "Mecanismos alternativos de solución de conflictos...", Revista CESCO, $\mathrm{n}^{\circ} .14,2015$, p. 44 habla del "fracaso financiero (que no jurídico) del Sistema Arbitral de Consumo. En la situación actual, la sociedad no puede pagar el Sistema Arbitral de Consumo, es un «lujo de países ricos», propio del Estado del bienestar, tal y como se configuraba antes de la crisis, que ya no nos podemos permitir. Ha fracasado en nuestro país por falta de fondos".

125 A tenor del art. 133-4.5 - precepto introducido por la Ley 20/2014, de 29 de diciembre-, "Las administraciones públicas catalanas y, especialmente, los servicios públicos de consumo deben fomentar y estimular que las empresas que otorgan créditos o préstamos hipotecarios sobre la vivienda incluyan en las condiciones generales o específicas su adhesión al arbitraje de consumo".

126 Fuera del ámbito concreto de las entidades crediticias, son legión las leyes de consumo que se refieren al fomento del arbitraje de consumo: a título de ejemplo, el art. 40 de la Ley de Defensa de los Consumidores de La Rioja (Ley 5/2013, de 12 abril); o el art. 27.2 del Estatuto del Consumidor de Castilla y León (Ley 2/2015, de 4 de marzo). 
"persuadir" y convencer a las entidades bancarias de lo muy ventajoso -para ellasde someterse al mismo ${ }^{127}$.

Con todo, más problemático, a mi entender, es que el art. 133-1.2 del citado Código de Consumo catalán establezca - bajo la rúbrica «Procedencia del arbitraje»- una presunción de sumisión al arbitraje por las entidades crediticias (siempre que éstas no se hayan opuesto al mismo previamente a la conclusión del contrato con el consumidor); una suerte de sumisión "semi-forzosa" al arbitraje, que se concreta -textualmente- en que «En materia de créditos y préstamos hipotecarios que tienen por objeto la vivienda habitual, se entiende que la empresa prestamista acepta el convenio arbitral siempre y cuando no haya manifestado expresamente al prestatario la voluntad en contra antes de la firma del contrato» ${ }^{128}$.

Pues bien, esta "presunción ope legis" de aceptación tácita del convenio arbitral por parte del prestamista es de dudosa constitucionalidad, a la luz de lo que sobre el derecho a la tutela judicial estableciera la Sentencia del Pleno del TC 174/1995, de 23 de noviembre, respecto de las Juntas Arbitrales de Transporte ${ }^{129}$.

En cualquier caso, lo que parece meridianamente claro es que no cabría "imponer" el arbitraje - a diferencia de lo que en breve veremos ocurre con la mediación-, pues un arbitraje "obligatorio", "imperativo" o "preceptivo", además de ser una auténtica contradicción en los términos, habría de tildarse de inconstitucional, en cuanto que

127 También considera que el sistema arbitral se revela en la práctica como un procedimiento ineficaz, inoperante y deficiente para resolver el fenómeno del sobreendeudamiento del deudor hipotecario BASTANTE GRANELL, V., "Mediación hipotecaria...", Anales de Derecho, $\mathrm{n}^{\circ} .31,2013$, pp. 184-185, n. 9, para quien "es lógico que las entidades bancarias no se acojan a un sistema arbitral para solucionar el problema de sobreendeudamiento hipotecario... Los bancos no tienen interés en someterse a un procedimiento cuya resolución es vinculante y tampoco en permitir que sea un árbitro el que establezca y decida la reestructuración hipotecaria".

128 Inmediatamente antes, en el párrafo 1, el artículo 133-1 dispone que "el arbitraje procede si existe un convenio arbitral previo entre las partes. En caso contrario, la Administración debe promover la formalización del convenio arbitral para resolver el conflicto mediante el arbitraje de consumo".

129 Declaró el TC en esta Sentencia que "la autonomía de la voluntad de las partes -de todas las partes- constituye la esencia y el fundamento de la institución arbitral, por cuanto que el arbitraje conlleva la exclusión de la vía judicial. Por tanto, resulta contrario a la Constitución que la Ley suprima o prescinda de la voluntad de una de las partes para someter la controversia al arbitraje de la Junta [Arbitral de Transporte], que es lo que se hace en el párrafo primero del artículo 38.2 [de la Ley de Ordenación de Transportes Terrestres]. La primera nota del derecho a la tutela consiste en la libre facultad que tiene el demandante para incoar el proceso y someter al demandado a los efectos del mismo... Quebranta, por tanto, la esencia misma de la tutela judicial tener que contar con el consentimiento de la parte contraria para ejercer ante un órgano judicial una pretensión frente a ella. Esto es exactamente lo que hace el artículo 38.2, párrafo primero, de la LOTT, que, al exigir un pacto expreso para evitar el arbitraje y acceder a la vía judicial, está supeditando el ejercicio del derecho a la tutela judicial efectiva de una de las partes al consentimiento de la otra, lo que, por las razones que han quedado expuestas, resulta contrario al artículo 24.1 de la Constitución". 
vendría a configurarse como un sistema judicial B, cuando nuestra Constitución (art. 117.6) prohíbe que existan tribunales especiales o tribunales $B$.

\section{LA MEDIACIÓN HIPOTECARIA COMO SISTEMA DE NEGOCIACIÓN ASISTIDA ANTE EL RIESGO DE LANZAMIENTO DE LA VIVIENDA HABITUAL}

\section{Intermediación y mediación hipotecaria: aproximación conceptual}

A modo de cuestión previa y antes de entrar de lleno en materia, conviene comenzar advirtiendo que las figuras de la mediación hipotecaria y la intermediación, lejos de hallarse nítidamente diferenciadas, aparecen con frecuencia entremezcladas tanto en la normativa legal como, por caso, en las webs de las Administraciones autonómicas y municipales o de los Colegios de abogados, donde se brindan y se ponen tales vías a disposición de los deudores asfixiados por sus hipotecas y en riesgo de perder su vivienda por el impago del préstamo ${ }^{130}$.

Con todo, a efectos distintivos, y muy brevemente, en la llamada "intermediación" nos encontramos con que el consumidor va a negociar con su entidad bancaria, sirviéndose para ello de un mero interlocutor ${ }^{131}$; pero éste, en rigor, actúa simplemente como una especie de nuntius o portavoz del deudor hipotecario, de modo que se trata en verdad de una negociación directa. Como ya se ha apuntado en la doctrina, en la intermediación los "encargados de la misma desarrollan una labor de asesoramiento u orientación y/o una labor de representación del usuario a la hora de realizar la encomienda de negociaciones en nombre de aquél con la entidad bancaria"132. Desde esta perspectiva, el Consejo General de la Abogacía Española indica que "la intermediación facilita la comunicación entre la parte deudora y la entidad financiera para encontrar una solución antes de una demanda de ejecución hipotecaria o durante el proceso de ésta"133. Y siguiendo esa pauta, valga como ejemplo la Oficina de Intermediación Hipotecaria del Principado de Asturias ${ }^{134}$, donde se contempla la intermediación hipotecaria como un "servicio de asesoramiento $\mathrm{y}$ atención que trata de facilitar que los afectados consigan

130 También CEBALlOS PEÑA, D., "La mediación hipotecaria...", Revista de Mediación, $\mathrm{n}^{\mathrm{o}} .12,2013$, p. 26 se ha percatado de la frecuente "confusión terminológica de MediaciónIntermediación, por lo que resulta preciso escindir ambos términos o conceptos".

131 De "interlocución" entre deudor y acreedor hipotecario se habla expresamente, y de forma reiterada, en el Manual de Procedimiento del Servicio Integral de Apoyo a Familias en Riesgo de Desahucio de Castilla y León (Decreto 58/2014, de 11 de diciembre, por el que se aprueba el Catálogo de Servicios Sociales).

132 Vid. CEBALLOS PEÑA, D., "La mediación hipotecaria...", Revista de Mediación, $\mathrm{n}^{\circ} .12$, 2013, p. 29.

133 Así se explica en la página del Consejo General de la Abogacía sobre la Oficina de Intermediación Hipotecaria (http://www.abogacia.es/2012/06/21/oficina-de-intermediacionhipotecaria).

134 Concretamente en el Convenio de colaboración, suscrito en 2012 y renovado el 5 de noviembre de 2015 con el Colegio de Abogados de Oviedo, para prestar un "servicio gratuito de intermediación a deudores hipotecarios". 
reestructurar de forma viable su deuda, o lograr una quita en el capital pendiente de amortización, o la dación en pago de su vivienda""135.

Por su parte, en la mediación hipotecaria stricto sensu, los objetivos últimos a alcanzar son estos mismos; pero aquí, en cuanto sistema $\mathrm{ADR}^{136}$, el tercero mediador tiene propiamente intervención en la negociación con la entidad crediticia. Es, pues, una negociación asistida que aquél dirige, guía, canaliza y modula, tratando de acercar las posiciones de las partes - sin perjuicio de que, dada la naturaleza autocompositiva de dicho sistema, el mediador no imponga la solución al conflicto y carezca de poder decisorio y sean los mismos interesados los que, en última instancia, vayan a llegar (o no) al acuerdo ${ }^{137}-$.

\section{Pros y contras para alcanzar acuerdos de mediación hipotecaria}

\subsection{Asimetría negocial y trabas fácticas}

A partir de la referida acepción, y sin poder obviar que en la mediación hipotecaria hay una desproporción o desequilibrio palmario entre las partes (el consumidor deudor y la entidad bancaria acreedora) ${ }^{138}$-ello por más que la presencia del mediador, "imparcial y neutral", tienda a garantizar que la parte más débil sea oída y

135 Vid. en igual sentido el art. 3.1.b) del ya citado Decreto-ley 2/2013, de Castilla y León, por el que se adoptan medidas extraordinarias de apoyo a las personas y familias afectadas por la crisis en situación de vulnerabilidad o riesgo de exclusión social.

136 Aunque prescindimos de entrar en el debate sobre la calificación técnica de la mediación hipotecaria, sí interesa dejar constancia de que, frente a quienes le otorgan "autonomía propia" y la configuran como una "mediación sui generis", como una tipología propia de ADR (BLANCO GARCÍA, A.I., "La intermediación hipotecaria...”, RIEDPA, n.2, 2015, pp. 14-15, 17-19; COBAS COBIELLA, Ma..E., "La intermediación hipotecaria en sede de ejecuciones hipotecarias: luces y sombras sobre la cuestión”, CEFLegal, n.160, 2014, p. 19), otros autores le niegan tal entidad autónoma y consideran que se trata de "una especialidad de la mediación de consumo, puesto que centra su actividad en una determinada clase de consumidores: los deudores hipotecarios; en un ámbito concreto de su protección: la reestructuración del préstamo hipotecario y la evitación de la ejecución; y en la defensa de un específico bien de uso o consumo común, ordinario y generalizado de protección prioritaria: la vivienda" (BASTANTE GRANELL, V., "Mediación hipotecaria...", Anales de Derecho, ${ }^{\circ} .31$, 2013, pp. 190-191).

137 De ahí que siempre cabría elucubrar acerca de si existe demasiada diferencia a efectos prácticos (o no tanta) entre negociar bajo la dirección y guía de un mediador propiamente dicho o negociar directamente, a través de un interlocutor; esto es, acerca de si son o no tantas y tan importantes como se suele postular, las ventajas de la primera vía frente a la segunda. Vid. al respecto GARCÍA-ÁLVAREZ, Ma .R., “¿Para qué necesito un mediador si puedo negociar por mí mismo?”, La Ley, nº.8087, 2013.

138 Escribe con carácter general ALONSO PÉREZ, Ma.T., "El Código de Buenas Prácticas...", RDCiv., $\mathrm{n}^{\circ} .2,2015$, p. 62 que "en cualquier relación crédito-deuda, el deudor se encuentra en una natural situación de inferioridad; cuando éste tiene dificultades para el pago, el desequilibrio se agrava. Y si el acreedor dispone de una garantía hipotecaria el poder del acreedor es casi absoluto", lo que limita mucho "la capacidad de negociación del deudor". 
que en el proceso de autocomposición sean tenidas en cuenta en pie de "igualdad" las pretensiones de ambas partes ${ }^{139}$-, surge el interrogante. ¿Qué puede hacer, en esta tesitura, que los bancos se presten a acuerdos en un proceso de mediación hipotecaria? ${ }^{140}$.

139 En su estudio de la mediación hipotecaria, también CEBALLOS, D., "La mediación hipotecaria...", Revista de Mediación, $\mathrm{n}^{\circ} .12,2013$, p. 26 deja constancia de que en ella "nos encontramos con una situación de desigualdad manifiesta entre la Entidad Bancaria y el usuario solicitante, circunstancia esta que desvirtúa totalmente un proceso de mediación strictu sensu, no sólo respecto al equilibrio de poderes en la negociación sino también en el rol del propio mediador".

A partir de la innegable premisa de la existencia de un desequilibrio de fuerzas entre las partes en la contratación bancaria con consumidores -pues "las entidades de crédito siempre han sido (y son) la parte fuerte de la relación contractual"-, BLANCO GARCÍA, A.I., "La intermediación hipotecaria...", RIEDPA, n ${ }^{\circ} .2,2015$, pp. 4, 14 y 18 señala que en materia de mediación hipotecaria "la realidad práctica del procedimiento ha manifestado la desvirtuación de esta institución de la mediación, no solo respecto del equilibrio de poder que debe existir en toda negociación sino también en el rol del mediador". En sede hipotecaria -afirma la autora- "las funciones del tercero son normalmente asumidas por un abogado -el abogado defensor del deudor-, posicionado claramente a favor del deudor (al que representa), de forma que hace las veces de asesor y consejero de las posibles medidas a adoptar para restablecer el equilibrio entre acreedor y deudor hipotecarios en la relación contractual. Aunque pudiera resultar extraña esta posibilidad porque las técnicas ADR van asociadas a la independencia, imparcialidad y neutralidad del tercero, la configuración en la práctica de este nuevo procedimiento así lo permite". Vid. igualmente VALL RIUS, A., "La intermediación...”, Revista Digital MM, nº.2, 2012, pp. 8-9.

En una línea similar, BALLUGUERA GOMEZ, C., "El servicio de ayuda al sobreendeudamiento familiar de Euskadi y la mediación en préstamos hipotecarios", Bilbao, 26 abril 2012 (www.notariosyregistradores.com) afirma que "en la hipoteca, a la igualdad o semejanza de poder contractual de las partes, base de la negociación, se llega aumentando el poder de la parte más débil, la persona consumidora".

Por su parte, BASTANTE GRANELL, V., "Mediación hipotecaria...", Anales de Derecho, $\mathrm{n}^{\circ} .31,2013$, pp. 188-189 destaca que no puede pasar desapercibida "la posición de debilidad que ocupa el deudor como consumidor en la fase de negociación y de posible reestructuración del préstamo hipotecario. Los deudores hipotecarios negocian con la entidad prestamista asfixiados por la cuerda de la hipoteca, en condiciones de urgencia y necesidad, en una situación económica negativa y con el miedo a perder la vivienda... Negociar solo en tales condiciones puede ser perjudicial para sus intereses económicos y beneficiar, en ocasiones, a la entidad prestamista". De ahí que concluya que la mediación hipotecaria debe "desempeñar una función tuitiva del consumidor en la fase de negociación y reestructuración del préstamo hipotecario". Con todo, al analizar más adelante los principios de imparcialidad y neutralidad que deben guiar la mediación hipotecaria (p. 201), puntualiza dicho autor que el mediador "no puede representar los intereses de ninguna de las partes" y que "proteger al deudor y tratar de salvaguardar su vivienda no implica dejar de respetar las posiciones de cada una de las partes y garantizar la igualdad en la negociación".

140 Ello sin entrar en las formalidades de los acuerdos de mediación para ser vinculantes y adquirir fuerza ejecutiva (cfr. en general art. 517.2 LEC y art. 25 Ley 5/2012 de Mediación en Asuntos Civiles y Mercantiles; sin perjuicio de las singularidades de la mediación intrajudicial y de la mediación previa del procedimiento arbitral de consumo, ex art. 38 RD 231/2008). Ampliamente sobre el tema, vid. p.ej. LÓPEZ BARBA, E., "La eficacia ejecutiva del acuerdo alcanzado tras un procedimiento de mediación según la Ley 
Como ya antes dije en relación con el arbitraje de consumo, nadie cede ante su derecho sin un cálculo de costes de todo tipo (comparativamente con los costes de un proceso judicial). En consecuencia, hay razones de peso que, a priori, no van a inclinar a las entidades bancarias a que la mediación hipotecaria llegue a buen puerto $^{141}$.

De un lado, nos topamos de nuevo con la situación jurídico-legal “formalmente” aplicable -porque, en rigor, y nos guste o no, si el deudor no ha pagado, el acreedor podría hacer valer sin más su garantía en un procedimiento de ejecución hipotecaria ${ }^{142}$. Es decir, también en sede de mediación resulta delicado delimitar la "materia negociable"143, cuando el conflicto consiste en que una parte quiere ejecutar su garantía y cobrar y la otra parte no puede o no quiere pagar, pero tampoco perder su vivienda ${ }^{144}$.

5/2012", RDPatr., no.30, 2013; BUSTO LAGO, J.M., "El control judicial...”, AC-M, nº.7, 2010; y PARDO IRANZO, V., La ejecución del acuerdo de mediación, Cizur Menor, Aranzadi, 2014.

141 Aun sin referirse específicamente a la mediación hipotecaria, TRUCHERO CUEVAS, J., "Cuando el incentivo es no pactar", La Ley, $\mathrm{n}^{\circ} .8507,2015$ explica los diversos factores por los que las empresas no tienen apenas aliciente para alcanzar acuerdos extrajudiciales.

142 En esta misma línea, también ALONSO PÉREZ, Mª.T., "El Código de Buenas Prácticas...", RDCiv., n'.2, 2015, p. 62 destaca que el acreedor hipotecario "desde un punto de vista jurídico, detenta una posición fuerte frente al deudor": "si el acreedor dispone de una garantía hipotecaria el poder del acreedor es casi absoluto, pues, incumplida la deuda, en cualquier momento puede ejecutar la garantía y cobrar. Por lo tanto, las circunstancias recortan, cuando no anulan, la capacidad de negociación del deudor a la hora de proponer una salida a su situación de dificultad para hacer frente al pago y que esquive la ejecución hipotecaria". Insistiendo en esas ideas, y tras destacar que en sede de realización de la hipoteca "el punto de partida es de absoluto predominio del acreedor y que dicha relación de poder es legítima porque está amparada en la ley", añade la autora que, a fin de impedir la ejecución hipotecaria que tanto perjudica al deudor, "la única posibilidad de favorecer a este deudor es contar con la voluntad del acreedor que, obviamente, sólo estará dispuesto a no ejecutar la garantía... si el mecanismo alternativo no le perjudica demasiado" (p. 63).

Por su parte, BASTANTE GRANELL, V., "Mediación hipotecaria...", Anales de Derecho, $\mathrm{n}^{\circ} .31,2013$, p. 188, n.18, aunque defiende la viabilidad y eficiencia de la mediación hipotecaria y subraya que, puesto que "la banca es la primera interesada en la pervivencia del préstamo hipotecario, en los últimos años ha mostrado una buena actitud para evitar las ejecuciones hipotecarias, como así lo demuestra el considerable número de refinanciaciones", no deja de reconocer, sin embargo, que "la banca lógicamente va a actuar conforme a su propio interés económico. Las entidades financieras velan por sus intereses, no son ONG's que ayudan a los deudores hipotecarios".

$143 \mathrm{Al}$ igual que ya indicamos respecto del arbitraje de consumo, también en la mediación es menester que el conflicto verse sobre una materia de libre disposición -tal como expresamente reclaman, por ejemplo, el art. 131-2.3 del Código de Consumo de Cataluña o el art. 3 del Decreto catalán de 8 julio 2014 sobre el Procedimiento de Mediación en las relaciones de consumo-.

144 Como observa BASTANTE GRANELL, V., "Mediación hipotecaria...", Anales de Derecho, $\mathrm{n}^{\circ} .31,2013$, p. 197, en la mediación hipotecaria cada una de las partes implicadas "tiene una percepción distinta de la situación. El deudor percibe al banco como la entidad que hizo un buen negocio con el préstamo y pretende despojarle de su 
De otro lado, importa también el cálculo de costes procesales -que el banco puede asumir mucho más fácilmente que el consumidor ${ }^{145}$, cuando, además, la cuantía litigiosa en juego no es baladí-.

\subsection{Circunstancias actuales favorables al éxito de la mediación ante el desahucio de la vivienda habitual}

Sin embargo, también hay factores que, en el convulso momento presente y en el escenario socio-económico en que hoy en día nos encontramos, sí contribuyen a hacer posibles eventuales acuerdos de mediación hipotecaria. Entre esos factores, aparte del escaso interés de la entidad bancaria en adjudicarse un inmueble más y acumular así a sus activos viviendas con salida muy poco rentable en el depreciado mercado inmobiliario actual ${ }^{146}$, creo que hay uno fundamental y especialmente

vivienda, mientras que el banco percibe al deudor como la persona que no quiere cumplir su obligación".

145 Como en términos generales, y aun sin aludir concretamente a los desahucios hipotecarios, señala TRUCHERO CUEVAS, J., "Cuando el incentivo es no pactar", $L a$ Ley, $\mathrm{n}^{\circ} .8507,2015$, uno de los elementos que explican la desigual distribución de incentivos entre empresas y consumidores para alcanzar acuerdos extrajudiciales estriba en que "los costes de acceso a la justicia son muy superiores para los consumidores, que no cuentan con asesoramiento jurídico estable, tienen un acceso a la información mucho más limitado y su capacidad para financiar costes de abogado, procurador o tasas judiciales es inferior".

Ampliamente sobre el tema, vid. STÜRNER, M., "ADR and adjudication by State Courts: competitors or complements?", en The role od consumer ADR in the Administration of justice, München, Sellier European, 2015, pp. 11-29.

146 En este sentido, también ALONSO PÉREZ, Ma.T., "El Código de Buenas Prácticas...", RDCiv., $\mathrm{n}^{\circ} .2,2015$, p. 63 afirma que, entre las circunstancias económicas coyunturales que "debilitan" en cierta medida la posición de las entidades crediticias, interesa tomar en consideración que la ejecución hipotecaria puede suponer un problema para éstas en un contexto en que el mercado inmobiliario ha provocado la depreciación de los inmuebles, de modo que "la incorporación de inmuebles a sus activos podría suponer un agravamiento de la crisis financiera que están sufriendo". Vid. igualmente VALL RIUS, A., "La intermediación en problemáticas hipotecarias", Revista Digital MM, $\mathrm{n}^{\mathrm{o}} .2,2012$, pp. 15-16.

Asimismo, destaca SERRANO GARCÍA, I., "Soluciones legales en materia de desahucios...", RJNot., $\mathrm{n}^{\circ} .86-87,2013$, p. 100 que la negativa repercusión de la crisis económica en las entidades de crédito y bancarias deriva, entre otras cosas, de que, "como consecuencia de los impagos y de las ejecuciones se están quedando con un gran número de viviendas, cuando no es su negocio la comercialización de bienes inmuebles”. Según recuerda el citado autor (p. 181), los propios bancos se han hecho eco de tal problema; y así, puede leerse en el Diario Expansión del día 13 de enero de 2013 que "en el Santander lo tenemos muy claro -dijo Botín-, el desahucio es la última y peor opción para todos: para nuestros clientes y también para el banco".

En una línea similar, BLANCO GARCÍA, A.I., "La intermediación hipotecaria...", RIEDPA, $\mathrm{n}^{\circ} .2,2015$, p. 7 apunta que el problema de los desahucios se ha convertido en el verdadero quebradero de cabeza de los deudores hipotecarios, pero "también de las entidades de crédito, por cuanto su interés no pasa por convertirse en grandes inmobiliarias -que lo son- sino que lo que buscan es recuperar el dinero prestado". 
poderoso: lo que podríamos llamar la "hostilidad ambiental". Es decir, que ante la situación creada ante la opinión pública ${ }^{147}$, el banco se enfrenta a fuertes costes de imagen si persevera en el litigio, éste desemboca en el lanzamiento del ciudadano de su vivienda habitual y, en consecuencia, se pone materialmente al deudor y su familia en la calle ${ }^{148}$. Baste hacer mención de la enorme fuerza social y mediática, y hoy ya política, de los diversos movimientos, asociaciones y plataformas de afectados por las hipotecas (PAH) y Stop Desahucios ${ }^{149}$.

De igual modo, expone BASTANTE GRANELL, V., "Mediación hipotecaria...", Anales de Derecho, $\mathrm{n}^{\circ} .31,2013$, p. 185 , n. 10 que el procedimiento de ejecución hipotecaria, ante la escasez actual de postores (que obliga a las entidades financieras a adjudicarse las viviendas), provoca -además del efecto fatídico de que el deudor hipotecario se ve despojado de su vivienda, permaneciendo endeudado por el saldo negativo que no se haya podido satisfacer con el valor de la adjudicación- la consecuencia, también preocupante y perturbadora, de que "la entidad acreedora adquiere un bien inmueble que debe provisionar, conforme dispone la normativa del Banco de España, y que constituye un activo tóxico imposible de vender a buen precio en el actual mercado inmobiliario, en continua recesión". De ahí que el acreedor hipotecario -añade dicho autor (pp. 198199)-, ante el riesgo de "tener que adjudicarse una vivienda sin salida en el mercado inmobiliario, sea el primer interesado en que perviva el préstamo hipotecario y en efectuar una adecuada reestructuración del mismo. No obstante -puntualiza-, dicho interés puede variar dependiendo de la cantidad de capital amortizado". Así, explica BASTANTE GRANELL (n. 42) que "las entidades financieras no pretenden adquirir o adjudicarse la vivienda y suelen estar dispuestas a hablar para alcanzar soluciones que resuelvan las morosidades hipotecarias. Sin embargo, pueden no tener interés en negociar. Si el deudor tiene amortizada una gran parte de la deuda, al banco le interesará posiblemente la ejecución hipotecaria, pero si la situación es al contrario, y el deudor ha amortizado una pequeña parte del préstamo, al banco le interesará mantener el mismo, siendo más proclive a la mediación hipotecaria y a la búsqueda de soluciones. Ello porque cuando existe una gran cantidad pendiente de amortizar, el saldo vivo del préstamo obliga a la entidad a provisionar, en la ejecución no obtendría el valor suficiente para cubrir la deuda y la adjudicación del bien supondría costes adicionales para la entidad, interesando a la entidad acreedora la mediación hipotecaria, y consecuentemente, la pervivencia del préstamo hipotecario".

147 DÍEZ GARCÍA, H., "Igualdad de armas y tutela judicial...", DPyC, nº.28, 2014, p. 206 alude a "la corriente social, política y mediática contraria a toda medida de efectividad de la garantía hipotecaria", a la idea de que las "entidades de crédito eran y son percibidas por la ciudadanía como seres despiadados, como seres sin alma".

También VALL RIUS, A., "La intermediación...", Revista Digital MM, nº.2, 2012, pp. 4 y 16 llama la atención sobre el escaso "prestigio corporativo y social" de los bancos y el "estado de opinión e indignación generalizado que reclama medidas para abordar situaciones realmente desesperadas... y superar situaciones de sobreendeudamiento hipotecario ciertamente agobiante".

148 Según apunta BLANCO GARCÍA, A.I., "La intermediación hipotecaria...", RIEDPA, $\mathrm{n}^{\circ} .2,2015$, p. 20, la renegociación con las entidades de crédito y el dato de que la inmensa mayoría de éstas hayan suscrito el Código de Buenas Prácticas responde "no solo a la finalidad de resolver las dificultades de los deudores hipotecarios, sino también como estrategia para mejorar su reputación y buena imagen ante la clientela". Vid. igualmente RODRÍGUEZ LÓPEZ, J., "Ejecuciones hipotecarias...", RDCiv., nº.3, 2014, p. 115.

149 Señala al respecto BLANCO GARCÍA, A.I., "La intermediación hipotecaria...", RIEDPA, $\mathrm{n}^{\circ} .2,2015$, p. 10 que "lo más destacable de este movimiento es el fuerte lobby 
Pero es más. Se percibe incluso - siquiera de lege ferenda- una cierta "hostilidad jurídica" hacia las entidades bancarias. Y es que la propia Directiva 17/2014 sobre Contratos de crédito celebrados con consumidores para bienes inmuebles de uso residencial dispone textualmente en su art. 28.1 («Demoras y ejecución hipotecaria») que "los Estados miembros adoptarán medidas para alentar a los prestamistas a mostrarse razonablemente tolerantes antes de iniciar un procedimiento de ejecución" $" 150$.

\section{Voluntariedad vs. obligatoriedad de la mediación}

\subsection{Tasas de eficiencia de la mediación hipotecaria voluntaria}

Aunque hemos formulado genéricamente los aludidos factores y circunstancias (a favor y en contra de la mediación), se hace preciso matizar su repercusión según que el proceso de mediación hipotecaria tenga carácter puramente voluntario o que, por el contrario, concurra la hipótesis de que aparezca configurado en términos preceptivos.

La voluntariedad se ha reputado, tradicionalmente, como principio esencial de la mediación; y así aparece plasmado tanto en la Ley estatal de Mediación (art. 6 Ley 5/2012) como en diversas normas autonómicas ad hoc: por ejemplo, en la Ley de Defensa de los Consumidores de La Rioja (Ley 5/2013, de 12 abril), que en el art. 39 configura la mediación como un "mecanismo de resolución voluntaria de reclamaciones en materia de consumo"; o en los arts. 2.1 y 5 del Decreto catalán 98/2014, de 8 de julio de 2014, sobre el Procedimiento de Mediación en las relaciones de consumo -Decreto que incorpora en Cataluña la Directiva 11/2013 de Resolución Alternativa de litigios de consumo- ${ }^{151}$.

existente contra las injusticias cometidas y, por ende, contra el abuso de poder de las entidades de crédito, pero también contra las actuaciones de los poderes públicos".

150 Incluso de lege data, y refiriéndose a la Ley $1 / 2013$, recuerda SERRANO GARCÍA, I., "Soluciones legales en materia de desahucios...", RJNot., n'.86-87, 2013, pp. 142-143 que en el Dictamen que sobre el proyecto de dicha Ley emitiera el Banco Central Europeo -dictamen firmado por el propio Mario Draghi- se recomienda enérgicamente evitar los desahucios, considerar la ejecución hipotecaria como "último recurso" y proporcionar incentivos para que las partes interesadas "acuerden una reestructuración de deuda oportuna y razonable en caso de incumplimiento". En vista de ello, habla el citado autor de "una efervescencia entre las fuerzas políticas y los grupos sociales" que ha tratado a toda costa "de intentar que los deudores no quedaran privados de vivienda", pero que nunca atendió al "problema de cómo remediar la situación del acreedor que no cobraba su crédito pero que al ser, por lo general, una entidad bancaria, se entendía -concluye SERRANO con un punto de ironía- que era la causante de todos los males y sus pretensiones no merecían atención".

151 Vid. además, entre otras muchas, los arts. 1.1 y 5 de la Ley de Mediación de Derecho Privado de Cataluña (Ley 15/2009); o el Decreto 12/2015, de 10 de febrero, por el que se crea el Centro aragonés de Coordinación en materia de mediación y el Registro de Mediadores e Instituciones de Mediación de Aragón y se establecen medidas de fomento 
Sobre la base de esa voluntariedad, son varias las Administraciones de Comunidades Autónomas (Cataluña ${ }^{152}$, País Vasco ${ }^{153}$, Aragón o Castilla y León, entre otras ${ }^{154}$ ) y de entidades locales ${ }^{155}$ o provinciales ${ }^{156}$ que, haciendo uso de sus competencias en materia de defensa de consumidores y usuarios o en el área de vivienda, han desarrollado experiencias de mediación hipotecaria voluntaria -con notable tasa de éxito $^{157}$-, sin que quepa obviar las iniciativas ensayadas por algunos organismos privados en ese campo.

de la mediación -Decreto que en su Parte Expositiva destaca la "voluntariedad" de la mediación-.

${ }^{152}$ La Generalitat de Cataluña fue pionera en instaurar, en enero de 2010, su Oficina de mediación hipotecaria bajo la denominación de OFIDEUTE, dependiente de la Agencia de Vivienda catalana (http://www.agenciahabitatge.cat/wps/portal?WCM_GLOBAL_ CONTEXT $=\mathrm{ca} / \mathrm{ahc} / \mathrm{web} /$ serveis/ciutada/ofideute).

153 En mayo de 2012 se creó, en el País Vasco, el Servicio de Mediación Hipotecaria, dependiente del Departamento de Justicia y Administración Pública, que constituye el eje central del Servicio de Ayuda al Sobreendeudamiento Familiar del Gobierno vasco. Vid. al respecto BALLUGUERA GOMEZ, C., "El servicio de ayuda al sobreendeudamiento familiar de Euskadi y la mediación en préstamos hipotecarios", Bilbao, 26 abril 2012 (www.notariosyregistradores.com).

154 Vid. también, por ejemplo, el Servicio de Orientación y Mediación Hipotecaria y de la Vivienda de la Comunidad Autónoma de la Región de Murcia (arts. 62-63 de la Ley murciana 6/2015, de 24 marzo, de la Vivienda); el Servicio de Mediación Hipotecaria de Navarra [art. 18.g) del Decreto Foral 128/2015, de 14 de agosto, sobre la estructura orgánica del Departamento de Derechos Sociales]; o el Programa de Mediación integral en materia de ejecuciones hipotecarias del Instituto de la Vivienda del Gobierno de La Rioja (http://www.irvi.es/mediacion_integral/index.html).

155 Sobre el apogeo de los servicios municipales de mediación hipotecaria, vid. BASTANTE GRANELL, V., "Mediación hipotecaria...", Anales de Derecho, nº.31, 2013, p. 196, n.39, quien recoge un amplio repertorio de ayuntamientos que ofrecen dichos servicios.

A modo de ejemplo, la Oficina de Mediación Hipotecaria del Ayuntamiento cántabro de Torrelavega resolvió con éxito el $87 \%$ de los casos en 2014 -frente al $60 \%$ de 2012-; soluciones que pasaron no tanto por la dación en pago de la vivienda, como por la refinanciación o reestructuración de la deuda con planes de aplazamiento de pago y algunas quitas de deuda (http://www.europapress.es/cantabria/noticia-oficina-mediacionhipotecaria-resolvio-exito-87-casos-2014-20150223171859.html). Para una exposición del procedimiento seguido por esa concreta Oficina municipal de Mediación Hipotecaria, puesta en marcha en septiembre de 2011, vid. CEBALLOS, D., "La mediación hipotecaria...", Revista de Mediación, $\mathrm{n}^{\mathrm{o}} .12$, 2013, pp. 24-26.

156 Algunas Diputaciones Provinciales (como las de Granada y Málaga, entre otras) prestan actualmente servicios institucionalizados de mediación hipotecaria (vid. BASTANTE GRANELL, V., "Mediación hipotecaria...", Anales de Derecho, no.31, 2013, p. 193, n.32).

157 Una defensa a ultranza del valor y eficiencia de este cauce voluntario de resolución extrajudicial de los conflictos hipotecarios lleva a cabo BLANCO GARCÍA, A.I., "La intermediación hipotecaria: la mejor opción contra ejecución hipotecaria", RIEDPA, $\mathrm{n}^{\circ} .2$, 2015 , pp. 4, 7, 10, 12, 15-16 y 27, quien insistentemente califica la mediación como "el medio de tutela que se ha revelado como idóneo, altamente beneficioso y más eficaz para paliar y mejorar las circunstancias económicas y personales de los deudores afectados". También se confiesan firmes partidarios de la mediación hipotecaria COBAS COBIELLA, Ma.E., "La intermediación hipotecaria...”, CEFLegal, no .160, 2014, pp. 5-40; 


\subsection{Mediación hipotecaria obligatoria: problemas de constitucionalidad, de respeto al Derecho europeo y de "oportunidad" de su imposición. Referencia particular a la mediación hipotecaria preceptiva en el Código de Consumo de Cataluña}

En contraste con la aludida nota de voluntariedad que por lo común preside las mediaciones hipotecarias, interesa, sin embargo, prestar sobre todo atención a aquellos sistemas que vienen a desplazar dicho rasgo y a establecer la obligatoriedad de la mediación hipotecaria -como paso preceptivo previo, antes de poder incoarse un procedimiento judicial de ejecución hipotecaria de la vivienda habitual del consumidor-. Tal es el caso del art. 132-4 del Código de Consumo de Cataluña $^{158}$, introducido por la Ley $20 / 2014$, de 29 de diciembre ${ }^{159}$.

VALL RIUS, A., "La intermediación...”, Revista Digital MM, nº.2, 2012, pp. 13-17; SÁNCHEZ HERNÁNDEZ, C., "Garantía hipotecaria, mercado y crisis...", RDPatr., $\mathrm{n}^{\circ} .35,2014 ;$ y BASTANTE GRANELL, V., "Mediación hipotecaria...", Anales de Derecho, $\mathrm{n}^{\circ} .31,2013$, pp. 209-212, quien expone sus múltiples virtudes, recoge diversos informes y noticias que señalan porcentajes de éxito ciertamente notables de dicho sistema y concluye que el mismo está permitiendo que "un buen número de deudores hipotecarios encuentre una salida" y que muchos de ellos "estén siendo ayudados por los distintos servicios de mediación hipotecaria, evitándose desahucios, pérdida de viviendas, o, al menos, impidiendo que ciertos deudores continúen al borde del «abismo» hipotecario".

158 Bajo la rúbrica «Créditos o préstamos hipotecarios», dispone este artículo lo siguiente:

"1. Las administraciones públicas catalanas y, especialmente, los servicios públicos de consumo deben garantizar que, en los casos de ejecución hipotecaria de la vivienda habitual como consecuencia del incumplimiento del deudor, pueda llevarse a cabo un procedimiento de mediación destinado a la resolución extrajudicial de conflictos previo a cualquier otro procedimiento judicial o a la intervención notarial.

2. El procedimiento de mediación debe tener por objeto buscar acuerdos entre las partes que hagan viable que la persona consumidora conserve la propiedad de la vivienda $\mathrm{o}$, subsidiariamente, la posibilidad de mantener su uso y disfrute. En el marco de este procedimiento, las partes o el órgano de resolución extrajudicial de conflictos pueden solicitar un informe de evaluación social con un análisis socioeconómico del deudor y las posibles vías de resolución del conflicto en los términos del artículo 133-6.

3. Las partes en conflicto, antes de interponer cualquier reclamación administrativa o demanda judicial, deben acudir a la mediación o pueden acordar someterse al arbitraje. Una vez transcurrido el plazo de tres meses a contar de la notificación del acuerdo de inicio de la mediación sin haber alcanzado un acuerdo satisfactorio, cualquiera de las partes puede acudir a la reclamación administrativa o a la demanda judicial.

4. En situaciones de sobreendeudamiento derivado de relaciones de consumo, la mediación corresponde a las comisiones de sobreendeudamiento, reguladas por su legislación específica. Si las comisiones de sobreendeudamiento no alcanzan un acuerdo entre el consumidor y los acreedores, queda abierta la correspondiente vía judicial para hacer efectivo lo dispuesto por este código y la legislación complementaria".

Un detallado estudio del contenido del transcrito art. 132-4 del Código de Consumo catalán (elementos subjetivos y legitimación activa en la mediación hipotecaria preceptiva, supuestos en que ésta se impone, plazo para llegar a acuerdos de mediación, etc.) lleva a cabo ADAN DOMENECH, F., “¿Instauración de una ejecución hipotecaria especial en Cataluña?”, La Ley, nº.8631, 2015. 
Conviene tener en cuenta que el Pleno del Tribunal Constitucional, mediante Providencia de 6 de octubre de 2015 (JUR 2015\239027), admitió a trámite el recurso de inconstitucionalidad ${ }^{160}$ promovido por el Gobierno central contra dicho artículo y decretó, con efectos desde el 30 de septiembre de 2015, la suspensión de la vigencia del mismo (y demás preceptos impugnados). Sin embargo, nótese que la posible tacha de inconstitucionalidad deriva de razones competenciales, de que la Comunidad Autónoma de Cataluña ha emanado una norma que podría invadir, entre otras, la competencia exclusiva del Estado en materia de legislación procesal (art. 149.6 CE) ${ }^{161}$-al imponerse por el Parlamento catalán un requisito procedimental previo e instaurarse así, de facto, una suerte de procedimiento "especial" de ejecución hipotecaria en Cataluña-.

Pero, problemas competenciales al margen, y suponiendo que hubiera sido una ley estatal la que hubiese dictado esa norma que obliga a intentar la mediación como trámite preceptivo previo para poder interponer una demanda judicial de ejecución hipotecaria sobre la vivienda habitual, ¿sería ello inconstitucional?

No faltan autores que entienden que sí $^{162}$, porque -a su juicio- perjudica y obstaculiza el acceso a la justicia, introduciendo barreras y limitaciones en el

También analiza con detenimiento dicho precepto PÉREZ DAUDÍ, V., “Aspectos procesales de la mediación preceptiva en los procesos hipotecarios", La Ley, no.8541, 2015; autor que se centra en particular en las repercusiones procesales de la obligación de intentar la mediación antes de iniciar un proceso de ejecución hipotecaria sobre la vivienda habitual, desarrollando en especial las consecuencias de la falta del intento de la mediación previa y las relaciones entre ésta y el proceso judicial posterior. Asimismo MERELLES, M., "Mediación en el ámbito de los servicios bancarios y suministros básicos", La Ley, $\mathrm{n}^{\circ} .8532,2015$ examina tanto los requisitos subjetivos y objetivos de aplicación de la mediación hipotecaria obligatoria prevista en el Derecho catalán, como su tratamiento procesal; estudio del que concluye que, además de llevarse por delante el principio de voluntariedad en la mediación, "la reforma catalana introduce un elemento distorsionador y de difícil encaje en las normas procesales".

Interesa advertir que, con posterioridad, la Ley 24/2015, de 29 de julio, de Medidas urgentes para afrontar la emergencia en el ámbito de la vivienda y la pobreza energética de Cataluña, ha regulado un procedimiento extrajudicial para la resolución de la situación de sobreendeudamiento de los consumidores derivada de una relación de consumo. De esta manera, los consumidores, así como cualquiera de sus acreedores, pueden solicitar un procedimiento extrajudicial -una mediación- para la resolución de dicha situación salvo que se encuentren inmersos en un procedimiento concursal (art. 2.1).

Pues bien, dado que la concesión de un préstamo o crédito hipotecario para la adquisición de una vivienda es una relación de consumo, ya en la doctrina se ha evidenciado la problemática que plantea la necesidad de conjugar las referidas medidas previstas en la Ley 24/2015 con las disposiciones del Código de Consumo catalán sobre la mediación hipotecaria obligatoria (vid. NASARRE, S./SIMÓN, H., "Un paso más en la protección de los deudores hipotecarios de vivienda...”, RDBB, $\mathrm{n}^{\circ} .139,2015$, pp. 47-48, n. 149).

160 Recurso de inconstitucionalidad $\mathrm{n}^{\circ} .5459-2015$.

161 Cfr. STC de 22 abril 2013 (RTC 2013/92).

162 Vid. en particular, CONFORTI, Ó.D.F., "Mediación de consumo en Cataluña versus tutela judicial efectiva: ¿Una apostasía en la resolución de conflictos?”, La Ley, nº.8534, 2015. Aludiendo concretamente al art. 132-4 del Código de Consumo de Cataluña, y tras 
derecho a la tutela judicial efectiva, consagrado tanto en el art. 24 CE como en el 47 de la Carta Europea de Derechos Fundamentales.

Sin embargo, yo creo que en sí no es inconstitucional ${ }^{163}$. De un lado, porque la mediación hipotecaria obligatoria no impide o veda el acceso a los tribunales, no vulnera ni restringe el derecho a la tutela judicial ${ }^{164}$, quedando expedita esta vía judicial si no se alcanza acuerdo ${ }^{165}$.

plantearse si "es constitucional la obligación de mediar antes de litigar" y "cómo encaja constitucionalmente la obligación de iniciar un proceso de mediación previo a acudir a la vía jurisdiccional", el citado autor concluye que "la obligatoriedad de iniciar un proceso de mediación de forma previa para acudir a la jurisdicción no es un requisito constitucional, y por tanto, podría configurar una violación al derecho fundamental de acceso a la jurisdicción contemplado en el art. 24 CE".

Aunque más tibiamente, PÉREZ DAUDÍ, V., “Aspectos procesales de la mediación preceptiva...", La Ley, nº.8541, 2015 considera, con carácter general, que la mediación obligatoria está llamada a "a lastrar el ejercicio del derecho de acceso a la justicia".

163 Especialmente si la norma se aplica hacia el futuro y no de forma retroactiva.

164 En este sentido, la Sentencia del TJUE de 18 marzo 2010 (TJCE 2010 78]) -al hilo de la resolución extrajudicial de litigios en materia de servicios de comunicaciones electrónicas entre usuarios finales y proveedores, conforme a la Directiva 2002/22/CE- declaró que el hecho de que una normativa nacional haya dispuesto la obligatoriedad del recurso a un procedimiento de ADR con carácter previo al ejercicio de una acción judicial no vulnera el derecho a la tutela judicial efectiva (siempre que, entre otros requisitos, no implique un retraso sustancial a la vía judicial, suspenda la prescripción de los correspondientes derechos y no ocasione gastos o estos sean poco significativos).

165 También se decantan por afirmar rotundamente la inexistencia de vulneración alguna del derecho de acceso a los tribunales, ADAN DOMENECH, F., "¿Instauración de una ejecución hipotecaria especial en Cataluña?", La Ley, nº.8631, 2015; y NASARRE, S./SIMÓN, H., "Un paso más en la protección de los deudores hipotecarios de vivienda...”, RDBB, no.139, 2015, p. 49.

Contrarios a que la mediación obligatoria constituya una traba al acceso a la justica se muestran igualmente GINEBRA MOLINS, Ma.E.TARABAL BOSCH, J., "La obligatoriedad de la mediación derivada de la voluntad de las partes: las cláusulas de mediación", InDret, no.4, 2013. Aun partiendo de que "la voluntariedad constituye la esencia de la mediación" y es "uno de sus principios nucleares, si no el primordial" (p. 4), y pese a que mediación y obligatoriedad pudieran parecer conceptos antitéticos (p. 6), puntualizan dichos autores que tal principio es susceptible de ciertas modulaciones respecto al inicio del procedimiento; ductilidad que se manifiesta, precisamente, en la llamada "mediación obligatoria" (mandatory mediation). Sin embargo -explican-, sostener que la mediación obligatoria representa un obstáculo para el acceso a los tribunales o que es impeditiva de la efectiva tutela judicial de los ciudadanos "no deja de ser una falacia" (pp. 19-20 y 27), pues -sin perjuicio de la imposición legal de intentar la mediación- la naturaleza intrínsecamente voluntaria de esta figura no admite ningún tipo de interferencia en cuanto a la libertad de las partes de desistir o abandonar el proceso de mediación en cualquier momento o de alcanzar o no un acuerdo (pp. 4, 20, 27). 
De otro lado, y sin perjuicio de las diferencias, más o menos sutiles, entre conciliación y mediación ${ }^{166}$, cabe recordar que ya en el ámbito de ciertos procesos laborales ${ }^{167}$ se impone un trámite previo de conciliación obligatoria ${ }^{168}$.

Pero además, y aunque es cierto que el art. 131-1 del Código de Consumo catalán comienza afirmando que la sumisión a los sistemas extrajudiciales es voluntaria y el art. 132-2.1 y 2 incluye expresamente la voluntariedad entre los principios rectores de la mediación de consumo -lo que entraña una cierta contradicción con lo luego dispuesto en el art. 132-4 que ahora nos ocupa-, en verdad la previsión de una mediación hipotecaria preceptiva no es contraria a la normativa europea en la materia: en concreto, no se opone a la Directiva $11 / 2013^{169}$, que admite que los sistemas ADR para la resolución de conflictos de consumo se implementen en los Estados miembros con carácter ya voluntario, ya obligatorio (Considerandos $45^{\circ} \mathrm{y}$ $49^{\circ}$ y art. 1); ni tampoco contradice la Directiva 17/2014 que, para los contratos de crédito con consumidores para bienes inmuebles de uso residencial, alude

166 Aun no siendo completamente pacífica su distinción, y sin perjuicio de las polémicas doctrinales acerca de los concretos límites entre conciliación y mediación, se halla relativamente extendida la opinión de que los criterios básicos para su diferenciación estribarían en la cualidad del tercero ante quien se intenta la avenencia, así como en el rol que el mismo adopta y la intensidad de su respectivo grado de participación en una y otra modalidad extrajudicial de resolución del conflicto. Vid. BARONA VILAR, S., Solución extrajurisdiccional de conflictos: Alternative Disputes Resolution (ADR) y Derecho Procesal, Valencia, Tirant lo Blanch, 1999, p. 81; MARCOS FRANCISCO, D., "El arbitraje de consumo como medio extrajudicial...", Revista de Derecho Universidad Católica del Norte, $\mathrm{n}^{\circ} .1,2011$, p. 259; HINOJOSA SEGOVIA, R., Sistemas de solución extrajurisdiccional de conflictos, Madrid, Centro de Estudios Ramón Areces, 2006, p. 169; CUCARELLA GALIANA, L.A., "La mediación en Derecho privado en el contexto de las otras fórmulas de resolución de controversias distintas al proceso", RGDProc., $\mathrm{n}^{\circ} .26$, 2012; CANO GALÁN, Y., "Conflictos laborales y su solución", en MARTÍNEZ GARRIDO, L.R., Práctica Procesal Laboral, T.I, Barcelona, Bosch, 2007, pp. 132-133; y ampliamente sobre el tema, SEMPERE NAVARRO, A.V. (Dir.), La solución extrajudicial de los conflictos laborales, León, Eolas, 2014.

167 Vid. arts. 63 a 68 (en especial, art. 66.1) de la Ley 36/2011, de 10 de octubre, reguladora de la jurisdicción social.

168 Interesa recordar que el Defensor del Pueblo, en su Informe de 25 de enero de 2012 «Crisis económica y deudores hipotecarios: actuaciones y propuestas del Defensor del Pueblo», incluyó -como Recomendación 4.2.6- el "Intento de acuerdo previo como requisito de procedibilidad en las ejecuciones hipotecarias", afirmando que "sería deseable que antes de acudir al procedimiento judicial elegido se establezca la obligación de intento de conciliación previa, al igual que existe en otros procesos judiciales". Asimismo en la actualización de 9 de abril de 2013 de dicho Informe, se indica que el Defensor del Pueblo volvió a insistir en noviembre de 2012 en la recomendación de "establecer la necesidad de un acto previo de conciliación, como requisito de procedibilidad para la ejecución hipotecaria, en el que el juez esté dotado de la facultad de imponer un acuerdo razonable".

169 Comparten esta opinión BARRAL VIÑALS, I., "Si no queda satisfecho...", Revista CESCO, no.14, 2015, pp. 4-5; y NASARRE, S./SIMÓN, H., "Un paso más en la protección de los deudores hipotecarios de vivienda...”, RDBB, nº.139, 2015, p. 49. 
expresamente en el Considerando $77^{\circ}$ a que la participación de los prestamistas en dichos procedimientos extrajudiciales "no sea facultativa"170.

Cuestión diferente a la de su posibilidad y legitimidad jurídica es -aunque esto ya sea otro cantar- la de la mayor o menor conveniencia de imponer esa obligatoriedad $^{171}$. Y es que si finalmente la entidad bancaria no se aviene al acuerdo, ese proceso de mediación hipotecaria infructuoso, en lugar de acelerar la solución del conflicto, la habrá demorado, ralentizado o retrasado en alguna medida ${ }^{172}$-pues,

170 Con carácter general, la propia Directiva 2008/52/CE, de 21 de mayo, sobre ciertos aspectos de la mediación en asuntos civiles y mercantiles -aun partiendo de la voluntariedad de la mediación [art. 3.a) y Considerando $13^{\circ}$ ]- deja un amplio margen a los legisladores nacionales para elegir el modelo, permitiendo que "el procedimiento sea iniciado por las partes, sugerido u ordenado por un órgano jurisdiccional o prescrito por el Derecho de un Estado miembro" [art. 3.a)]; es decir, que tenga carácter voluntario o carácter obligatorio. De ahí que, como explican GINEBRA, Ma..E./TARABAL, J., "La obligatoriedad de la mediación...", InDret, n".4, 2013, pp. 5-6, "la neutralidad de la Directiva admite que la mediación se configure como obligatoria" y permite, pues, que la ley ordene el intento de mediación como requisito de procedibilidad, como paso previo necesario antes de acudir a los tribunales. Vid. igualmente NASARRE, S./SIMÓN, H., "Un paso más en la protección de los deudores hipotecarios de vivienda...", $R D B B$, $\mathrm{n}^{\mathrm{o}} .139,2015$, p. 49.

171 No faltan quienes sostienen que instaurar en España la mediación hipotecaria obligatoria con carácter previo al proceso de ejecución hipotecaria "posiblemente ayude a disminuir la tensión social que existe en torno a los conflictos hipotecarios" (BASTANTE GRANELL, V., "Mediación hipotecaria...", Anales de Derecho, nº.31, 2013, p. 212).

En cambio, otros autores apuestan decididamente por el carácter voluntario de la mediación y se muestran contrarios a la conveniencia de perfilarla como obligatoria. Vid. en este sentido STROIE, I.R., “¿Es viable un modelo de mediación de consumo autónomo desde el punto de vista de las materias que puedan ser objeto de mediación?", Revista CESCO, $\mathrm{n}^{\circ} .14,2015$, p. 31, quien afirma que su imposición "no hace otra cosa que propiciar que la mediación sea un trámite previo vacío de contenido, pero necesario para acceder a la jurisdicción".

Asimismo AGUILÓ REGLA, J., El arte de la mediación. Argumentación, negociación y mediación; Trotta, Madrid, 2015, p. 103 escribe que "un peligro bien real de la emergente mediación en España es su desvirtuación burocrática, su conversión en un mero requisito procesal que hay que satisfacer (y costear) antes de litigar".

172 También PÉREZ DAUDÍ, V., “Aspectos procesales de la mediación preceptiva...”, La Ley, $\mathrm{n}^{\circ} .8541,2015$-haciéndose eco del Informe crítico que en su día emitiera el Consejo General del Poder Judicial acerca del Anteproyecto de la Ley estatal de mediación del año 2012 (Anteproyecto de 19 de febrero de 2010 que sí preveía la obligatoriedad del intento de mediación con carácter previo a determinados juicios verbales de escasa cuantía)entiende que el recurso obligatorio a la mediación "es una medida que por sí sola no favorecerá el descenso de la litigiosidad, sino que implicará una mayor dilación procedimental". Abundando en el riesgo de que la mediación opere como un trámite ineficaz y meramente dilatorio, recuerda el autor -de nuevo a la luz del citado Informe del CGPJ- que "no parece que tenga mucho sentido instaurar supuestos de mediación obligatoria cuando... se pueden convertir en meros trámites previos sin una verdadera efectividad, pues lo único que ello supondrá es la agregación de nuevas cargas".

Una opinión diferente sobre el particular defienden GINEBRA MOLINS, $M^{a}$.E./TARABAL, J., "La obligatoriedad de la mediación...", InDret, $n^{\circ} .4,2013$. Tras 
a la postre, la ejecución hipotecaria va a acabar en sede judicial-, con lo que, por otro lado, tampoco se habrá logrado el tan manido objetivo de descongestionar la justicia $^{173}$ y aligerar el volumen y sobrecarga de trabajo de nuestros colapsados tribunales.

\section{BIBLIOGRAFÍA}

ACHÓN BRUÑEN, Ma.J.: “Adecuación del procedimiento judicial hipotecario a la normativa europea: Sentencia del TJUE de 14 de marzo de 2013", en La Ley, $n^{\circ} .8065,18$ abril 2013.

- "Modificaciones del proceso de ejecución por la Ley de medidas para reforzar la protección a los deudores hipotecarios, reestructuración de deuda y alquiler social: deficiencias y problemas prácticos", en La Ley, n.8087, 21 mayo 2013.

- "Diversidad de criterios judiciales en relación con los efectos de la declaración de nulidad de las cláusulas relativas a intereses en las escrituras de hipoteca. La esperada STJUE de 21 de enero de 2015: una luz con muchas sombras", en La Ley, nº.8473, 4 febrero 2015.

recordar que, por mor del carácter autocompositivo de la mediación, la imposición legal de acudir a ella no garantiza la resolución del conflicto por vía de acuerdo, dichos autores se plantean hasta qué punto la mediación preceptiva no sería un rodeo ocioso y la utilidad efectiva de la figura no quedaría en entredicho (p. 20). A fin de dar una respuesta -negativa- a este interrogante, y si bien comienzan por reconocer que se producirá un "retraso de la solución jurisdiccional en caso de que finalmente las partes terminen resolviendo sus diferencias ante los tribunales" (p. 24), GINEBRA y TARABAL se decantan finalmente por restar valor a ese argumento contrario a la conveniencia de la mediación obligatoria, afirmando que "considerar que pueda suponer un retraso relevante" al acceso a los tribunales es "una falacia" (pp. 20 y 27). Por otra parte, a su juicio, y como contrapunto que serviría para compensar sobradamente el riesgo de dicho retraso, concluyen que "los beneficios de la mediación pueden convencer incluso a los más escépticos si entran en contacto con ella": "el mero hecho de tener que intentarla puede ¿por qué no? contribuir a convencer a las partes de la bondad de resolver sus diferencias por esta vía", y es que "incluso partes inicialmente reticentes acaban valorando positivamente intentarla después de ser «obligadas» a ello" (pp. 21 y 23).

En una línea similar, y refiriéndose concretamente a la mediación hipotecaria obligatoria establecida en el Derecho catalán, apuntan NASARRE, S./SIMÓN, H., "Un paso más en la protección de los deudores hipotecarios de vivienda...", $R D B B, \mathrm{n}^{\circ} .139,2015$, p. 50 que, dado que el párr. 3 del art. 132-4 del Código de Consumo de Cataluña establece un "plazo de tres meses" para alcanzar, en su caso, un acuerdo de mediación, ese periodo tiempo "no implica un retraso sustancial a efectos del ejercicio de una acción judicial".

173 Recoge este objetivo expresamente, p.ej. la Parte Expositiva del ya citado Decreto $12 / 2015$ por el que se crea el Centro aragonés de coordinación en materia de mediación y el Registro de mediadores e Instituciones de mediación de Aragón y se establecen medidas de fomento de la mediación. 
- "Comentario crítico de las modificaciones introducidas en el procedimiento de ejecución hipotecaria por la Ley 19/2015, de 13 de julio", en La Ley, $n^{\circ} .8619,2$ octubre 2015.

ADAN DOMENECH, F.: "¿Instauración de una ejecución hipotecaria especial en Cataluña?", en La Ley, n.8631, 23 octubre 2015.

AGÜERO ORTIZ, A.: "Comentario e interpretación de la nueva Directiva en materia hipotecaria (Directiva 2014/17/UE). Una Directiva para proteger a las entidades de crédito y a la propia Unión Europea”, en Publicaciones Jurídicas del Centro de Estudios de Consumo (CESCO), 15 julio 2014 (http://www.uclm.es/centro/cesco/pdf/trabajos/33/15j.pdf).

- "Sinhogarismo": Estrategia Nacional Integral para personas sin hogar 20152020", en Publicaciones Jurídicas del Centro de Estudios de Consumo (CESCO), 22 noviembre 2015 (www.uclm.es/centro/cesco).

- "Nueva Sección dedicada al Código de Buenas Prácticas Bancarias en la Web del Ministerio de Economía y Competitividad", en Publicaciones Jurídicas del Centro de Estudios de Consumo (CESCO), 18 febrero 2016 (www.uclm.es/centro/cesco).

AGUILAR OLIVARES, Y.: "Un paso más hacia el consumidor europeo: la nueva regulación de los ADR de consumo", en Revista CESCO de Derecho de Consumo, n.14, 2015 (http://www.revista.uclm.es/index.php/cesco).

AGUILÓ REGLA, J.: El arte de la mediación. Argumentación, negociación y mediación; Trotta, Madrid, 2015.

ALASTRUEY, R.: "La mediación ante la ejecución hipotecaria: una oportunidad para la dignidad, un ejercicio de responsabilidad social", en El Notario del siglo XXI, n.46, noviembre-diciembre 2012.

ALCALÁ DÍAZ, Ma.Á.: La protección del deudor hipotecario: Ley 1/2013, de 14 de mayo, de medidas para reforzar la protección a los deudores hipotecarios, reestructuración de deuda y alquiler social, Cizur Menor, Thomson ReutersAranzadi, 2013.

- "La protección del deudor hipotecario. La insuficiencia de la reforma para la defensa del deudor-consumidor", en La Notaría, n.2, 2013.

- "La reforma de la normativa de protección del deudor hipotecario", en Hacia un nuevo modelo de mercado hipotecario, coord. por ALCALÁ DÍAZ, Mª.Á., Madrid, Dykinson, 2014.

ALONSO PÉREZ, Ma.T.: "Cláusulas frecuentes en préstamos hipotecarios para adquisición de vivienda: cláusula suelo, cláusula de vencimiento anticipado y cláusula de intereses moratorios excesivamente elevados (en particular, su posible carácter abusivo)", en Vivienda y crisis económica (Estudio jurídico de las medidas propuestas para solucionar los problemas de vivienda provocados por la crisis económica), dir. por ALONSO PÉREZ, Ma.T., Cizur Menor, Thomson Reuters-Aranzadi, 2014. 
- “El Código de Buenas Prácticas de reestructuración viable de las deudas con garantía hipotecaria sobre la vivienda habitual (Naturaleza jurídica y su análisis como supuesto específico de sobreendeudamiento de particulares)", en Revista de Derecho Civil, $n^{\circ} .2$, abril-junio 2015.

ÁLVAREZ LATA, N.: "Notas a la STJUE de 18 de diciembre 2014 (asunto c449/13, Ca Consumer Finance SA vs I. Bakkaus; Mr. \& Mrs. Bonato). Obligaciones derivadas del principio de crédito responsable: primeras interpretaciones del TJUE", en Revista CESCO de Derecho de Consumo, n.13, 2015 (http://www.uclm.es/centro/cesco/pdf/trabajos/34/5.pdf).

ÁLVAREZ MORENO, $\mathrm{M}^{a}$.T.: “Aproximación a la normativa sobre mediación en litigios de consumo", en Revista de Derecho Privado, $n^{\circ} .100$, enero-febrero 2016.

ÁLVAREZ OLALLA, M‥P.: "La nueva normativa en materia de transparencia de servicios bancarios. La regulación del préstamo”, en Aranzadi CivilMercantil, $n^{\circ} .10,2012$.

ÁLVAREZ ROYO-VILLANOVA, S.: "Las ejecuciones hipotecarias en el contexto de la crisis", en El Notario del siglo XXI, n.36, marzo-abril 2011.

- "De nuevo en apoyo del deudor hipotecario. EL RDL 6/2012 y su Código de Buenas Prácticas", en El Notario del siglo XXI, n.42, mayo-abril 2012.

ÁLVAREZ SÁNCHEZ DE MOVELLÁN, P.: “Algunas cuestiones sobre la anulación judicial del laudo en la Ley 60/2003, de Arbitraje", en La Ley, n.4, 2004.

- "Procedimiento arbitral en la Ley de Arbitraje 60/2003 y supletoriedad en el arbitraje de consumo", en AA.VV. Protección de los consumidores e inversores, arbitraje y proceso, dir. por ARIZA COLMENAREJO, M ${ }^{\text {a.J./GALÁN }}$ GONZÁLEZ, C., Madrid, Reus, 2009.

ÁLVAREZ VEGA, M ${ }^{a} . I .$, La protección jurídica del consumidor sobreendeudado e insolvente, Cizur Menor, Thomson Reuters-Civitas, 2010.

ANGUITA RÍOS, R.Ma.: "De las reformas hipotecarias y otras alternativas", en Revista Crítica de Derecho Inmobiliario, n.745, 2014.

ANTA GONZÁLEZ, J.F.: “Una aproximación crítica a la Ley 1/2013, de 14 de mayo, de medidas para reforzar la protección a los deudores hipotecarios", en La Ley, $n^{\circ} .8237,27$ enero 2014.

ANTONIAZZI, C.: "Consideraciones acerca de la mediación ante la crisis económico-social actual”, en Revista General de Derecho Procesal, n.17, 2009.

BALLUGUERA GOMEZ, C.: "El servicio de ayuda al sobreendeudamiento familiar de Euskadi y la mediación en préstamos hipotecarios", Bilbao, 26 abril 2012 (www.notariosyregistradores.com).

- "Tope máximo de intereses de demora”, en Revista de Derecho Civil, n.1, enero-marzo 2014. 
BANACLOCHE PALAO, J.: "Cláusulas abusivas y suspensión de la ejecución hipotecaria”, en La Ley, n.8312, 2014.

BARONA VILAR, S.: Solución extrajurisdiccional de conflictos: Alternative Disputes Resolution (ADR) y Derecho Procesal, Valencia, Tirant lo Blanch, 1999.

- Mediación en asuntos civiles y mercantiles en España, Valencia, Tirant lo Blanch, 2013.

BARRAL VIÑALS, I.: “El cliente y el consumidor de servicios financieros de préstamo hipotecario", en LAUROBA LACASA, E. (Directora)/ TARABAL $\mathrm{BOSCH}$, J. (Coordinador), Garantías reales en escenarios de crisis: presente y prospectiva, Madrid, Marcial Pons, 2012.

- “¿Abusivas por falta de transparencia (bancaria)?: El control de incorporación y las cláusulas suelo en préstamos hipotecarios", en Revista de Derecho Privado, $\mathrm{n}^{\circ} .2$, marzo-abril 2015.

- "Si no queda satisfecho... ¡reclame!: El futuro de la resolución de conflictos de consumo", en Revista CESCO de Derecho de Consumo, n.14, 2015 (http://www.revista.uclm.es/index.php/cesco).

BASSOLS COMA, M.: "El derecho a la vivienda ante la crisis económica y el cambio climático: intervención de las administraciones públicas ante situaciones de vulnerabilidad social y urbanística", en Revista General de Legislación y Jurisprudencia, $\mathrm{n}^{\circ} .1,2011$.

BASTANTE GRANELL, V.: "Mediación hipotecaria: una solución al problema del sobreendeudamiento de los particulares", en Anales de Derecho, $\mathrm{n}^{\circ} .31$, 2013 (http://dx.doi.org/10.6018/analesderecho).

BATALLA CARILLA, J.L.: “El sistema no se hunde”, en Registradores de España, $n^{\circ} .64,2013$.

BEL I QUERALT, G./ESTRUCH MANJÓN, A.: "Crisis financiera y regulación. Tentación, pecado, penitencia y propósito de la enmienda", en El Cronista del Estado Social y Democrático de Derecho, n.4, 2009.

BERCOVITZ RODRÍGUEZ-CANO, R.: “El eco de la campanada”, en Aranzadi CivilMercantil, $n^{\circ} .9,2013$.

BERROCAL LANZAROT, A.I.: "La protección del deudor hipotecario en el actual contexto de crisis económica", en Cuadernos de Derecho y comercio, $n^{\circ} .58,2012$.

- "La vivienda hipotecada en la actual situación de crisis económica", en LAUROBA LACASA, E. (Directora)/ TARABAL BOSCH, J. (Coordinador), Garantías reales en escenarios de crisis: presente y prospectiva, Madrid, Marcial Pons, 2012.

- "La protección del deudor hipotecario a propósito de la sentencia del Tribunal de Justicia de la Unión Europea, sala primera, de 14 de marzo de 2013", en Revista Aranzadi doctrinal, $n^{\circ}$.2, mayo 2013 (westlaw BIB 2013\890). 
BLANCO CARRASCO, M.: "La alternativa de la mediación en conflictos de consumo: presente y futuro", en Anuario Jurídico y Económico Escurialense, 2009.

BLANCO GARCÍA, A.I.: "El Anteproyecto de Ley de Resolución Alternativa de Conflictos de Consumo y su encaje en el sector financiero", en Revista CESCO de Derecho de Consumo, n.15, 2015 (http://www.revista.uclm.es/ index.php/cesco).

- "La intermediación hipotecaria: la mejor opción contra ejecución hipotecaria”, en Revista Internacional de Estudios de Derecho Procesal y Arbitraje, $n^{\circ} .2$, 2015.

BUSTO LAGO, J.M.: "El control judicial del laudo arbitral de consumo en el procedimiento de ejecución", en Aranzadi Civil-Mercantil, n.7, 2010 (Westlaw, BIB 2010, 2168).

CALATAYUD CROS, L.: “Para que la mediación eche raíces precisa profesionales bien formados", en Blog de la Universidad Internacional Valencia (VIU), 18 febrero 2016 (http://www.viu.es/mediacion-precisa-profesionales-bienformados/).

CALVO HORNERO, A.: "La crisis de las hipotecas subprime y el riesgo de credit crunch", en Revista de Economía Mundial, nº.18, 2008.

CALVO SÁNCHEZ, Ma.C.: "Prólogo", en MARTÍN DIZ, F., La mediación: sistema complementario de administración de justicia, Madrid, CGPJ, 2010.

CANO GALÁN, Y.: “Conflictos laborales y su solución”, en MARTÍNEZ GARRIDO, L.R. (Dir.), Práctica Procesal Laboral, T.I, Barcelona, Bosch, 2007.

CARRASCO PERERA, Á.: “Tipo para subastas hipotecarias, rehabilitaciones, declaraciones de obra nueva y otras regulaciones inmobiliarias en el RDLey 8/2011", en La Ley, n.7698, 20 septiembre 2011.

- “Hipotecas y desahucios bajo el umbral de subsistencia”, en Actualidad Jurídica Aranzadi, n.842, 2012.

- "La corte de los milagros o la suspensión de lanzamientos hipotecarios", en Actualidad Jurídica Aranzadi, n.854, 5 diciembre 2012.

- "La Ley 1/2013, de 14 de mayo, de reforma hipotecaria y la articulación procesal del control sobre cláusulas abusivas en la ejecución hipotecaria", en Publicaciones Jurídicas del Centro de Estudios de Consumo (CESCO), 2013 (www.uclm.es/centro/cesco).

- "Hipotecas sin desahucios", en Desahucios y ejecuciones hipotecarias (un drama social y un problema legal), dir. por SÁNCHEZ RUIZ DE VALDIVIA, I./OLMEDO CARDENETE, M., Valencia, Tirant lo Blanch, 2014.

- "Presentación”, en MENDOZA LOSANA, A.I./GARCÍA MONTORO, L., "Mecanismos alternativos de solución de conflictos: Vías eficientes y sostenibles para tutelar los derechos del consumidor" (Acta del curso de 
verano 2015, 2 y 3 de julio 2015, Cuenca), en Revista CESCO de Derecho de Consumo, $n^{\circ}$.14, 2015 (http://www.revista.uclm.es/index.php/cesco).

CARRASCO PERERA, Á./LYCZKOWSKA, K.: “Un nuevo (y esta vez defectuoso) pronunciamiento del TJUE sobre el procedimiento hipotecario español", en Publicaciones Jurídicas del Centro de Estudios de Consumo (CESCO), 21 julio 2014 (www.uclm.es/centro/cesco).

CASADO CERVIÑO, A.: "El arbitraje de consumo", en Comentarios a la Ley de Arbitraje, coord. por MARTÍN MUÑOZ, A./HIERRO ANIBARRO, S., Madrid, Marcial Pons, 2006.

CASADO NAVARRO, A: "La normativa española sobre transparencia de préstamos hipotecarios ante la Directiva 2014/17/UE reguladora de los contratos de crédito para bienes inmuebles de uso residencial celebrados con consumidores", en La Ley, n.8636, 2 noviembre 2015.

CASARES PINAL, M.C.: “Mediación en materia hipotecaria”, en La mediación: nuevas realidades, nuevos retos. Análisis en los ámbitos civil y mercantil, penal y de menores, violencia de género, hipotecario y sanitario, dir. por CASTILLEJO MANZANARES y coord. por TORRADO TARRÍO, C., La Ley, Madrid, 2013.

CASTILLO MARTÍNEZ, C. del C.: Las cláusulas abusivas en los contratos de préstamo garantizado con hipoteca. Negociación contractual, desequilibrio importante y protección del consumidor en la contratación bancaria, Valencia, Tirant lo Blanch, 2016.

CATALÁN CHAMORRO, Ma.J.: "Reflexiones críticas en torno al Anteproyecto de Ley de Resolución Alternativa de Conflictos de Consumo", en Actualidad Jurídica Iberoamericana, $\mathrm{n}^{\circ} .3$, agosto 2015.

CATENA REAL, R.: “La reciente normativa en materia de transparencia referida a los préstamos hipotecarios”, en La Ley, n.8402, 2014.

CEBALLOS PEÑA, D.: "La mediación hipotecaria: un nuevo fenómeno de afrontamiento de conflictos en un entorno de crisis social", en Revista de Mediación, $\mathrm{n}^{\circ} .12,2^{\circ}$ semestre 2013 (revistademediacion.imotiva.es).

COBAS COBIELLA, Ma .E.: “La intermediación hipotecaria en sede de ejecuciones hipotecarias: luces y sombras sobre la cuestión”, en CEFLegal: Revista práctica de Derecho. Comentarios y casos prácticos, nº.160, mayo 2014.

CONFORTI, Ó.D.F.: “Mediación de consumo en Cataluña versus tutela judicial efectiva: ¿Una apostasía en la resolución de conflictos?", en La Ley, $\mathrm{n}^{\circ} .8534,7$ mayo 2015.

CORDERO LOBATO, E.: “Notas de urgencia sobre la paralización temporal de desahucios hipotecarios establecida en el Real Decreto-Ley 27/2012", en La Ley, n.7973, 2012.

- "La paralización de desahucios hipotecarios (RDL 27/2012, de 15 de noviembre, de medidas urgentes para reforzar la protección a los 
deudores hipotecarios)", en Revista CESCO de Derecho de Consumo, $\mathrm{n}^{\circ} .4$, 2012 (http://www.revista.uclm.es/index.php/cesco).

- "Control judicial sobre cláusulas abusivas y ejecuciones hipotecarias", en Revista Aranzadi Doctrinal, n.2, 2013 (westlaw BIB 2013\895).

- "Y ahora viene lo difícil: ¿Cómo controlar en el ejecutivo hipotecario el carácter abusivo de una cláusula?", en Revista CESCO de Derecho de Consumo, $n^{\circ} .5,2013$.

COUSO PASCUAL, J.R.: “La ejecución hipotecaria tras la Ley 1/2013", en El Notario del siglo XXI, $\mathrm{n}^{\circ} .49$, mayo-junio 2013.

CREUTZFELDT, N., "Alternative Dispute Resolution for Consumers", en STÜRNER, M./GASCÓN INCHAUSTI, F./CAPONI, E. (editores), The role od consumer ADR in the Administration of justice. New Trends in Access to Justice under EU Directive 2013/11, München, Sellier European Law Publishers, 2015.

CRUZ ZABAL, M./COBAS COBIELLA, Mª.: “¿Mediación Hipotecaria o Intermediación Hipotecaria?", en Mediación en el ámbito civil, familiar, penal e hipotecario: cuestiones de actualidad, coord. por BARONA VILAR, S./ORTEGA GIMÉNEZ, A./COBAS COBIELLA, M Ma.E., Madrid, Difusión Jurídica, 2013.

CUCARELLA GALIANA, L.A.: “La mediación en Derecho privado en el contexto de las otras fórmulas de resolución de controversias distintas al proceso", en Revista General de Derecho Procesal, $n^{\circ} .26$, enero 2012.

CUENA CASAS, M.: "Préstamo responsable, información crediticia y protección de datos personales", en Revista de Derecho Concursal y Paraconcursal, $n^{\circ} .20,2013$.

CUÑAT EDO, E.: "Reflexiones sobre las reglas de transparencia y protección del cliente de servicios bancarios", en Estudios de Derecho Mercantil, Libro homenaje al Dr. José Antonio Gómez Segade, coord. por TOBíO RIBAS, A.M ${ }^{a}$., T.I, Madrid, Marcial Pons, 2013.

DE LA FUENTE NÚÑEZ DE CASTRO, Mª.S.: “La dación en pago: ¿una solución eficaz a la situación socio económica del deudor inmobiliario?", en Revista CESCO de Derecho de Consumo, n.4, 2012 (http://www.revista.uclm.es/ index.php/cesco).

DE LA PEÑA, L./LÓPEZ-FRÍAS, J.: “Crédito responsable: un nuevo concepto en nuestro ordenamiento", en Revista de Derecho Bancario y Bursátil, n.130, 2013.

DE LUCCHI LÓPEZ-TAPIA, Y./RUIZ-RICO RUIZ, J.M.: “Aspectos procesales y civiles de la Ley 1/2013, de 14 de mayo, de medidas para reforzar la protección de los deudores hipotecarios", en Revista General de Derecho Procesal, $n^{\circ} .31,2013$.

DÍAZ ALABART, S.: “El concepto de consumidor en el arbitraje de consumo", en AA.VV. (editor: FLORENSA I TOMÁS, C.E.), El arbitraje de consumo: una 
nueva dimensión del arbitraje de derecho privado, Valencia, Tirant lo Blanch, 2004.

DÍAZ FRAILE, J.Ma .: “Limitación de la responsabilidad hipotecaria: revisión de la ejecución hipotecaria y de la dación en pago en el contexto de la actual crisis económica", en Revista Crítica de Derecho Inmobiliario, $\mathrm{n}^{\circ} .732$, 2012.

DÍEZ GARCÍA, H.: “Admisión e inadmisión a trámite de solicitudes de arbitraje de consumo", en Aranzadi Civil, n ${ }^{\circ}$ 14, diciembre 2007.

- Recargas hipotecarias e hipotecas recargables, Madrid, Reus, 2012.

- "Igualdad de armas y tutela judicial efectiva en el art. 695.4 LEC tras el Real Decreto-Ley 11/2014, de 5 de septiembre: crónica de una reforma legislativa anunciada (De los AATC 70/2014, 71/2014, 111/2014, 112/2014 y 113/2014 a la STJUE de 17 de julio de 2014)", en Derecho Privado y Constitución, $\mathrm{n}^{\circ} .28,2014$.

DOMÍNGUEZ LUELMO, A.: "Hipoteca de vivienda y otras hipotecas desde la perspectiva bancaria", en LAUROBA LACASA, E. (Directora)/ TARABAL $\mathrm{BOSCH}$, J. (Coordinador), Garantías reales en escenarios de crisis: presente y prospectiva, Madrid, Marcial Pons, 2012.

DOMÍNGUEZ RUIZ, L.: “El control judicial de cláusulas abusivas en el proceso de ejecución tras la reforma de la Ley $1 / 2013$, de 14 de mayo", en Revista General de Derecho Procesal, n.35, enero 2015.

EMBID IRUJO, A.: El Derecho de la crisis económica, Prensas Universitarias de Zaragoza, 2009.

ESPEJO LERDO DE TEJADA, M.: Vivienda, préstamo y ejecución, Cizur Menor, Aranzadi, 2016.

ESPLUGUES MOTA, C.: "Comentario al art. 34", en S. (Coord.), Comentarios a la Ley de Arbitraje (Ley 60/2003, de 23 de diciembre), coord. por S. BARONA VILAR, Madrid, Civitas, 2004.

ESTRADA ALONSO, E./FERNÁNDEZ CHACÓN, I.: “El futuro de la ejecución hipotecaria española tras la sentencia del Tribunal de Justicia de la Unión Europea, de 14 de marzo de 2013", en Revista Crítica de Derecho Inmobiliario, $\mathrm{n}^{\circ} .737,2013$.

ETXEBERRÍA GURIDI, J.F. (Director): Estudios sobre el significado e impacto de la mediación. ¿Una respuesta innovadora en los diferentes ámbitos jurídicos?, Cizur Menor, Thomson Reuters-Aranzadi, 2012.

FERNÁNDEZ DE SENESPLEDA, I./IZQUIERDO BLANCO, P./SERRA RODRÍGUEZ, A./SOLER SOLÉ, G.: Cláusulas abusivas en la contratación bancaria, Barcelona, Bosch, 2014.

FERNÁNDEZ ROZAS, J.C.: "Riesgos de la heterodoxia en el control judicial de los laudos arbitrales", en La Ley, n.8537, 12 mayo 2015. 
FERNÁNDEZ-SANCHO TAHOCES, A.S.: “Derecho a la vivienda y ejecución hipotecaria: valoración de las recientes reformas legales”, en La Ley, $n^{\circ} .8529,29$ abril 2015.

FERNÁNDEZ SEIJO, J.M.: La defensa de los consumidores en las ejecuciones hipotecarias, Barcelona, Bosch, 2013.

FLORENSA I TOMÁS, C.E.: "Prólogo", en AA.VV. (editor: FLORENSA I TOMÁS, C.E.), El arbitraje de consumo: una nueva dimensión del arbitraje de derecho privado, Valencia, Tirant lo Blanch, 2004.

FLORES DOÑA, Ma . de la S./RAGA GIL, J.T. (Directores), El préstamo hipotecario y el mercado del crédito en la Unión Europea, coord. por CALLEJO RODRÍGUEZ, C. y BERROCAL LANZAROT, A.I., Madrid, Dykinson, 2016.

FODDAI, Ma.A.: “Conciliación y mediación: ¿modelos diferentes de resolución de conflictos?”, en Mediación, arbitraje y resolución extrajudicial de conflictos en el siglo XXI, coord. por GARCÍA VILLALUENGA, L./TOMILLO URBINA, J./VÁZQUEZ DE CASTRO, E./FERNÁNDEZ CANALES, C., Vol.1 (Mediación), Madrid, Reus, 2010.

GARBERI LLOBREGAT, J.: La reforma de la ejecución y del desahucio hipotecarios, Barcelona, Bosch, 2013.

GARCÍA-ÁLVAREZ, Ma.R., “¿Para qué necesito un mediador si puedo negociar por mí mismo?”, en La Ley, $n^{\circ}$.8087, 21 mayo 2013.

GARCÍA CRESPO, J.M.: "Mercado hipotecario y seguridad jurídica”, en La Ley, $\mathrm{n}^{\circ} .7661,28$ junio 2011.

GARCÍA DE PABLOS, J.F.: “La protección de los deudores hipotecarios sin recursos", en La Ley, n.7819, 15 marzo 2012.

- "La nueva protección a los deudores hipotecarios", en Actualidad Jurídica Aranzadi, $\mathrm{n}^{\circ} .865,2013$.

GARCÍA MÁS, F.: “Ejecución de acuerdos alcanzados en mecanismos alternativos de resolución de conflictos y mecanismo de segunda oportunidad para el consumidor insolvente del artículo 242 bis de la Ley Concursal", en MENDOZA LOSANA, A.I./GARCÍA MONTORO, L., "Mecanismos alternativos de solución de conflictos: Vías eficientes y sostenibles para tutelar los derechos del consumidor" (Acta del curso de verano 2015, 2 y 3 de julio 2015, Cuenca), en Revista CESCO de Derecho de Consumo, n.14, 2015 (http://www.revista.uclm.es/index.php/cesco).

GARCÍA MONTALVO, J.: De la quimera inmobiliaria al colapso financiero, Barcelona, Bosch, 2008.

GARCÍA MONTORO, L., “"Nuevo” modelo de resolución alternativa de conflictos de consumo a la luz del Anteproyecto de Ley de Resolución Alternativa de Conflictos de Consumo. Especial referencia a las posibilidades de supervivencia de la mediación y otros mecanismos tradicionales", en Revista CESCO de Derecho de Consumo, n.14, 2015 (http://www.revista. uclm.es/index.php/cesco). 
- "La conciliación en la Ley 15/2015, de 2 de julio, de la Jurisdicción Voluntaria", en Publicaciones Jurídicas del Centro de Estudios de Consumo (CESCO), 12 octubre 2015 (http://www.uclm.es/centro/cesco).

GARCÍA RUBIO, M M.P.: "La obligación a cargo del profesional de evaluar la solvencia del consumidor prestatario", en La Ley-Unión Europea, n.16, 2014.

GÁZQUEZ SERRANO, L.: “Las cláusulas arbitrales en los contratos de arrendamientos urbanos", en Actualidad Civil, n.21-22, 2012.

GINEBRA MOLINS, Ma.E./TARABAL BOSCH, J.: “La obligatoriedad de la mediación derivada de la voluntad de las partes: las cláusulas de mediación", en InDret, $n^{\circ} .4$, octubre 2013.

GOMÁ LANZÓN, F.: “Análisis y crítica de la Orden EHA/2899/2011 de transparencia en los servicios bancarios", en El Notario del siglo XXI, n.40, noviembre-diciembre 2011.

GÓMEZ LOZANO, M‥M.: "Las medidas de protección del consumidor en la fase previa de contratación de préstamos hipotecarios: de la normativa española a la comunitaria", en AA.VV. La protección de los consumidores en tiempos de cambio, dir. por MIRANDA SERRANO, L.M., Madrid, lustel, 2015.

GONZÁLEZ CASSO, J.: "Otro puyazo a nuestro legislador. Comentario a la sentencia del TJUE de 29 de octubre de 2015", en La Ley, n.8670, 22 diciembre 2015.

GONZÁLEZ SÁNCHEZ, S.: “Debate global con un claro análisis coste-beneficio”, en Escritura Pública, n.12, marzo-abril 2013.

HERNÁNDEZ-GIL ÁLVAREZ-CIENFUEGOS, A.: "Comentario a los arts. 1 a 8 de la Ley 60/2003", en Comentarios a la Ley de Arbitraje, coord. por MARTÍN MUÑOZ, A./HIERRO ANIBARRO, S., Madrid, Marcial Pons, 2006.

HERNÁNDEZ SAINZ, E.: “EI nuevo régimen de protección precontractual en la contratación bancaria de préstamos hipotecarios", en Vivienda y crisis económica (Estudio jurídico de las medidas propuestas para solucionar los problemas de vivienda provocados por la crisis económica), dir. por ALONSO PÉREZ, Ma.T., Cizur Menor, Thomson Reuters-Aranzadi, 2014.

HINOJOSA SEGOVIA, R.: Sistemas de solución extrajurisdiccional de conflictos, Madrid, Centro de Estudios Ramón Areces, 2006.

HUALDE MANSO, T.: "Cláusulas abusivas del préstamo a consumidores y ejecución de la garantía hipotecaria”, en Aranzadi Civil-Mercantil, n.2, mayo 2013.

IGLESIAS ROSADO, G.: "Vías legales eficaces frente a los lanzamientos hipotecarios", en La Ley, n.8074, 2 mayo 2013.

IZQUIERDO CARRASCO, M.: "Régimen jurídico de la protección de la clientela en los servicios prestados por las entidades de crédito", en Derecho de la 
regulación económica, X, Sistema bancario, dir. por MUÑOZ MACHADO, S./VEGA SERRANO, J.M., Madrid, lustel, 2013.

JIMÉNEZ PARÍS, T.A.: “La reforma del Real Decreto-Ley 6/2012, de medidas urgentes de protección de deudores hipotecarios sin recursos por la Ley 1/2013, de 14 de mayo, anti-desahucios", en Revista Crítica de Derecho Inmobiliario, $\mathrm{n}^{\circ} .739,2013$.

JIMÉNEZ SEGADO, C.: Guía procesal ante el desahucio hipotecario, Madrid, Dykinson, 2015.

JUAN GÓMEZ, M.: “Reflexiones sobre la Ley 1/2013, de protección a los deudores hipotecarios", en Revista Crítica de Derecho Inmobiliario, $n^{\circ} .739$, 2013.

LACRUZ MANTECÓN, M.L.: “La moderna dación en pago”, en Revista de Derecho Civil, $\mathrm{n}^{\circ} .3$, julio-septiembre 2014.

LAFUENTE TORRALBA, A.J.: “El control judicial de cláusulas abusivas en la ejecución hipotecaria: luces y sombras de su regulación legal", en Vivienda y crisis económica (Estudio jurídico de las medidas propuestas para solucionar los problemas de vivienda provocados por la crisis económica), dir. por ALONSO PÉREZ, Mª.T., Cizur Menor, Thomson Reuters-Aranzadi, 2014.

- "Los obstáculos para el examen de cláusulas abusivas en el proceso de ejecución: puntos ciegos y zonas de desprotección en el régimen vigente", en Revista de Derecho Civil, n.2, abril-junio 2015 (http://nreg.es/ojs/ index.php/RDC).

LAPARRA, M./PÉREZ ERANSUS, B. (Coordinadores): Crisis y fractura social en Europa. Causas y efectos en España, Colección Estudios Sociales, nº.35, Edit. Obra Social de La Caixa, Barcelona, 2012.

LAUROBA LACASA, E.: “La Propuesta de Directiva del Parlamento Europeo y del Consejo sobre los Contratos de crédito relativos a los bienes inmuebles de uso residencial", en LAUROBA LACASA, E. (Directora)/ TARABAL BOSCH, J. (Coordinador), Garantías reales en escenarios de crisis: presente $y$ prospectiva, Madrid, Marcial Pons, 2012.

LAUROBA LACASA, E./ORTUÑO MUÑOZ, P. (Coordinadores), “Experiencias de Tribunales en mediación", en Mediación es justicia. El impacto de la Ley 5/2012, de mediación civil y mercantil, Editorial Huygens, Barcelona, 2015.

LLEDÓ YAGÜE, F.: “Algunas notas de interés en la tramitación de la Ley 1/2013, de 14 de mayo, de medidas para reforzar la protección a los deudores hipotecarios, reestructuración de la deuda y alquiler social. Y reflexiones a "vuela pluma" sobre cuestiones "técnicas" que plantea la ley", en Desahucios y ejecuciones hipotecarias (un drama social y un problema legal), dir. por SÁNCHEZ RUIZ DE VALDIVIA, I./OLMEDO CARDENETE, M., Valencia, Tirant lo Blanch, 2014. 
LÓPEZ AZCONA, A.: "El ámbito de aplicación de las medidas de protección de los deudores hipotecarios y sus (restrictivos) criterios delimitadores", en Revista General de Legislación y Jurisprudencia, n.1, enero-marzo 2015.

LÓPEZ BARBA, E.: "La eficacia ejecutiva del acuerdo alcanzado tras un procedimiento de mediación según la Ley 5/2012", en Revista de Derecho Patrimonial, $\mathrm{n}^{\circ} .30,2013$ (Westlaw, BIB 2013\520).

LÓPEZ JIMÉNEZ, J.M. (Director): La cláusula suelo en los préstamos hipotecarios, Barcelona, Bosch, 2013.

- "Revisión del marco jurídico hipotecario: condicionantes, limitaciones y consecuencias no deseadas", en La Ley, n.8063, 16 abril 2013.

LYCZKOWSKA, K.: "El TJUE confirma que la regulación española actual de la oposición en el procedimiento de ejecución hipotecaria es conforme al Derecho comunitario. Auto TJUE (Sala Primera) de 16 de julio de 2015 (asunto C-539/14)", en Publicaciones Jurídicas del Centro de Estudios de Consumo (CESCO), 28 agosto 2015 (www.uclm.es/centro/cesco).

- "El plazo para oponerse a la ejecución establecido por la Disposición Transitoria $4^{a}$ de la Ley $1 / 2013$ se opone a la normativa comunitaria. ¿La ignorancia de las leyes exime a los consumidores de su cumplimiento?", en Publicaciones Jurídicas del Centro de Estudios de Consumo (CESCO), 9 noviembre 2015 (www.uclm.es/centro/cesco).

- ¿¿Quedan todavía cláusulas de vencimiento anticipado no abusivas?”, en Publicaciones Jurídicas del Centro de Estudios de Consumo (CESCO), 25 noviembre 2015 (www.uclm.es/centro/cesco).

MARCOS FRANCISCO, D.: "Nueva perspectiva del arbitraje de consumo a la luz del Real Decreto 231/2008, de 15 de febrero, regulador del Sistema Arbitral de Consumo", en Revista General de Derecho Procesal, $n^{\circ} .16$, 2008.

- El arbitraje de consumo y sus nuevos retos, Valencia, Tirant lo Blanch, 2010.

- "El arbitraje de consumo como medio extrajudicial de resolución de conflictos en la normativa española", en Revista de Derecho Universidad Católica del Norte, $\mathrm{n}^{\circ} .1,2011$.

- "Consumidores, sujetos privilegiados en el nuevo paradigma de justicia civil europea: medidas procesales y extraprocesales para su protección", en InDret, $\mathrm{n}^{\circ} .3$, julio 2015.

MARÍN LÓPEZ, M.J., "Presente y futuro del arbitraje de consumo: cuarenta y tres cuestiones controvertidas", en Publicaciones Jurídicas del Centro de Estudios de Consumo, 2006 (http://www.uclm.es/centro/cesco/ pdf/trabajos/3/2006/3-2006.1.pdf).

- "Los intereses moratorios abusivos e intereses moratorios ilegales en la Ley 1/2013", en Publicaciones Jurídicas del Centro de Estudios de Consumo, 11 octubre 2013 (http://blog.uclm.es/cesco/files/2013/10.pdf). 
MARTÍN DIZ, F.: "Propuestas procesales ante la crisis hipotecaria inmobiliaria", en La Ley, n.7126, 3 marzo 2009.

MARTÍN FABA, J.Ma.: "Nuevas medidas contra el sobreendeudamiento del consumidor en la Ley 24/2015, de 29 de julio, de medidas urgentes para afrontar la emergencia en el ámbito de la vivienda y la pobreza energética de Cataluña", en Publicaciones Jurídicas del Centro de Estudios de Consumo (CESCO), 15 octubre 2015 (www.uclm.es/centro/cesco).

MARTÍN MATEO, R.: La gallina de los huevos de cemento, Madrid, ThomsonCivitas, 2007.

MARTÍN PASTOR, J.: “La Ley 1/2013 de medidas para reforzar la protección a los deudores hipotecarios, reestructuración de la deuda y alquiler social", en La Ley, $n^{\circ} .8085,17$ mayo 2013.

MARTÍNEZ DE SANTOS, A.: Sobre la ejecución hipotecaria inmobiliaria, ¿Puede evitarse la ruina del ejecutado?, Ediciones Foro Jurídico, Valencia, 2013.

- "El acto de conciliación en la nueva Ley de Jurisdicción Voluntaria”, La Ley, $\mathrm{n}^{\circ} .8699,10$ febrero 2016.

MARTÍNEZ ESCRIBANO, C.: "El control de transparencia y la validez de las cláusulas suelo", en AA.VV. Cláusulas suelo: ¿Se puede negociar con el banco?, Cizur Menor, Aranzadi, 2014.

MARTÍNEZ ESPÍN, P.: "El régimen de transparencia y protección del cliente de servicios bancarios", en Revista CESCO de Derecho de Consumo, $\mathrm{n}^{\circ} .5$, 2013.

MERELLES PÉREZ, M.: "Sanción por mala fe procesal por no intentar la mediación”, en La Ley, n.8490, 27 febrero 2015.

- "Mediación en el ámbito de los servicios bancarios y suministros básicos", en La Ley, $\mathrm{n}^{\circ} .8532,5$ mayo 2015.

- "La mediación como requisito previo de admisión de la demanda", en La Ley, $n^{\circ} .8682,15$ enero 2016.

MERINO HERNÁNDEZ, J.L.: Comentarios a la Ley 1/2013, de 14 de mayo, de medidas para reforzar la protección a los deudores hipotecarios, reestructuración de la deuda y alquiler social, Madrid, Editorial Francis Lefevre, 2013.

MIRALBELL GUERIN, L.M., "El revuelo de las cláusulas abusivas en las hipotecas", en La Ley, n.8214, 18 diciembre 2013.

MIRANDA SERRANO, L.M.: “Operaciones y contratos bancarios", en AA.VV. Derecho Mercantil, Vol. $7^{\circ}$ (La contratación bancaria), dir. por JIMÉNEZ SÁNCHEZ, G.J. y DÍAZ MORENO, A., 15ª ed., Madrid, Marcial Pons, 2013.

MOLLAR Y PIQUER, Mª.P./VILAR GONZÁLEZ, S.: "EI consumidor frente a la ejecución hipotecaria", en Revista jurídica de la Región de Murcia, n.46, 2013. 
MONDÉJAR PEÑA, M.I.: “La protección de los deudores hipotecarios frente a las ejecuciones hipotecarias de viviendas en tiempos de crisis", en LAUROBA LACASA, E. (Directora)/ TARABAL BOSCH, J. (Coordinador), Garantías reales en escenarios de crisis: presente y prospectiva, Madrid, Marcial Pons, 2012.

- "La protección de los deudores hipotecarios frente a las ejecuciones hipotecarias", en Desahucios y ejecuciones hipotecarias (un drama social y un problema legal), dir. por SÁNCHEZ RUIZ DE VALDIVIA, I./OLMEDO CARDENETE, M., Valencia, Tirant lo Blanch, 2014.

MORALES MUÑOZ, E.: “Arbitraje. Concepto. Naturaleza. Fundamento. Clases. Arbitrajes especiales”, en Actualidad Civil, n.17, 2007.

MORENO GARCÍA, L.: Cláusulas suelo y control de transparencia. Tratamiento sustantivo y procesal, Madrid-Barcelona-Buenos Aires, Marcial Pons, 2015.

MUNAR BERNAT, P.: "Códigos de Buenas Prácticas, reestructuración de la deuda y dación en pago", en La protección del deudor hipotecario. Aproximación a la Ley de Medidas para reforzar la protección a los deudores hipotecarios, reestructuración de deuda y alquiler social, dir. por NÚÑEZ IGLESIAS, Á. y coord. por ESCARTÍN IPIENS, J.A./MARTOS CALABRÚS, Mª.A., Granada, Comares, 2014.

NASARRE AZNAR, S.: “Malas prácticas bancarias en la actividad hipotecaria”, en Revista Crítica de Derecho Inmobiliario, $\mathrm{n}^{\circ} .727,2011$.

- "La vivienda en propiedad como causa y víctima de la crisis hipotecaria", en Teoría y derecho, $\mathrm{n}^{\circ} .16,2014$.

- "A legal perspective of the origin and the globalization of the current financial crisis and the resulting reforms in Spain", en KENNA, P. (Editor), Contemporary Housing Issues in a Globalized World, Ashgate Publishing, Londres, 2014.

NASARRE AZNAR, S./SIMÓN MORENO, H.: “Un paso más en la protección de los deudores hipotecarios de vivienda: la Directiva 2014/17/UE y la reforma del Código de Consumo de Cataluña por Ley 20/2014", en Revista de Derecho Bancario y Bursátil, n.139, julio-septiembre 2015.

NÚÑEZ IGLESIAS, Á.: “La suspensión de los lanzamientos en la ejecución hipotecaria", en Revista de Derecho Civil, n.1, enero-marzo 2014 (http://nreg.es/ojs/index.php/RDC).

ORDÁS ALONSO, M.: "Comentario al artículo 4.5 de la Ley de Arrendamientos Urbanos", en Comentarios a la Ley de Arrendamientos Urbanos, coord. por R. BERCOVITZ RODRÍGUEZ-CANO, Cizur Menor, Thomson Reuters-Aranzadi, $6^{\mathrm{a}}$ ed., 2013.

PARDO IRANZO, V.: La ejecución del acuerdo de mediación, Cizur Menor, Aranzadi, 2014.

PÉREZ CONESA, C.: "STJUE de 17 de julio de 2014 (Asunto C-169/14): el art. 7.1 de la Directiva 93/13/CEE se opone a un sistema de procedimiento de 
ejecución hipotecaria, como el español, en el que el deudor ejecutado no puede recurrir en apelación contra la resolución que desestima su oposición a la ejecución", en Aranzadi Civil-Mercantil, n.8, diciembre 2014.

- "Cláusulas abusivas, préstamo hipotecario y legislación interna: su reforma "a remolque" de la doctrina del Tribunal de Justicia de la Unión Europea", en Aranzadi Civil-Mercantil, n.5, julio 2015.

PÉREZ DAUDÍ, V.: “Las consecuencias de la STJUE de 17 de julio de 2014 en el proceso de ejecución hipotecaria”, en La Ley, n.8391, 3 octubre 2014.

- "Aspectos procesales de la mediación preceptiva en los procesos hipotecarios", en La Ley, n.8541, 18 mayo 2015.

PÉREZ DE MADRID CARRERAS, V.: "La protección del consumidor en la contratación bancaria", en AA.VV. Derecho (privado) de los consumidores, dir. por MIRANDA SERRANO. L.M. y PAGADOR LÓPEZ, J., Madrid, Marcial Pons, 2012.

PÉREZ HEREZA, J.: “¿Apoyo al deudor hipotecario? Legislar a base de parches: el Real Decreto-Ley 8/2011", en EI Notario del siglo XXI, n.39, septiembreoctubre 2011.

- "Propuestas para la protección del deudor hipotecario", en El Notario del siglo $X X I, n^{\circ} .41$, enero-febrero 2012.

- “¿Una Ley definitiva para la protección del deudor hipotecario?”, en El Notario del siglo XXI, n.49, mayo-junio 2013.

- "Las ejecuciones hipotecarias: tres decretos leyes y todavía a la espera de una reforma integral", en El Notario del siglo XXI, $n^{\circ} .46$, noviembre-diciembre 2012.

PERTIINEZ VÍLCHEZ, F.: "Falta de transparencia y carácter abusivo de la cláusula suelo en los contratos de préstamo hipotecario", en InDret, n.3, 2013.

- "Las cláusulas abusivas en los procesos de ejecución hipotecaria", en Desahucios y ejecuciones hipotecarias (un drama social y un problema legal), dir. por SÁNCHEZ RUIZ DE VALDIVIA, I./OLMEDO CARDENETE, M., Valencia, Tirant lo Blanch, 2014.

PRATS ALBENTOSA, L.: “Conflictos entre particulares, solución entre particulares: la conciliación”, en Escritura Pública, n.95, septiembreoctubre 2015.

RAMOS HERRANZ, I.: "Directiva sobre contratos de crédito para bienes inmuebles", en Revista de Derecho de los Negocios, $n^{\circ} .248,2011$.

RECARTE GARCÍA-ANDRADE, A.: "La crisis financiera internacional y el crack financiero español”, en La Ilustración liberal: revista española y americana, $\mathrm{n}^{\circ} .37,2008$.

RODRÍGUEZ ACHÚTEGUI, E.: “Ejecuciones hipotecarias", Revista Aranzadi Doctrinal, $\mathrm{n}^{\circ} .1,2012$. 
RODRÍGUEZ CÁRCAMO, J.M.: “Los asuntos Sánchez Morcillo: el recurso de apelación en el procedimiento de ejecución hipotecaria y el Derecho de la UE”, en La Ley, n.8613, 25 septiembre 2015.

RODRÍGUEZ LÓPEZ, J.: “Ejecuciones hipotecarias. Un año de la Ley 1/2013”, en Revista de Derecho Civil, nº.3, julio-septiembre 2014.

RODRÍGUEZ MARÍN, C.: "Los desahucios hipotecarios en España. Análisis desde una perspectiva legal y judicial", en Desahucios y ejecuciones hipotecarias (un drama social y un problema legal), dir. por SÁNCHEZ RUIZ DE VALDIVIA, I./OLMEDO CARDENETE, M., Valencia, Tirant lo Blanch, 2014.

RODRÍGUEZ PRIETO, F.: “La nueva ley de protección de los deudores hipotecarios: poco más (y de lo mismo)", en ¿Hay Derecho?, 13 mayo 2013 (http://hayderecho.com/2013/05/13).

ROJO FERNANDEZ-RÍO, Á.J.: "Problemas y cuestiones en torno al sobreendeudamiento e insolvencia de las familias españolas", en El futuro de la protección jurídica de los consumidores (Actas del l Congreso Euroamericano de Protección Jurídica de los consumidores), TOMILLO URBINA, J./ÁLVAREZ RUBIO, J., Cizur Menor, Thomson-Civitas, 2008.

ROY PÉREZ, C.: “La protección del consumidor en la contratación de productos y servicios bancarios: el crédito hipotecario", en LAUROBA LACASA, E. (Directora)/ TARABAL BOSCH, J. (Coordinador), Garantías reales en escenarios de crisis: presente y prospectiva, Madrid, Marcial Pons, 2012.

SABATER BAYLE, E.: “Intereses moratorios en contrato de préstamo hipotecario, Cláusula abusiva. Nulidad o moderación judicial (Comentario a la STJUE, Sala Primera, de 21 de enero 2015, Caso Unicaja Banco, S.A. y Otros v. José Hidalgo Rueda y Otros)", en Aranzadi Civil-Mercantil, nº.3, mayo 2015.

SAMANES ARA, C.: “La acción de anulación contra el laudo arbitral de consumo a la luz de la Ley 60/2003, de 23 de diciembre, de arbitraje", en AA.VV. Curso de mediación y arbitraje. Nuevos retos del arbitraje de consumo, Dirección General de Consumo del Gobierno de Aragón, 2005.

SÁNCHEZ GARCÍA, J.M .: “Legislación continuada de protección de los deudores hipotecarios hasta la Ley 1/2013", en La Notaría, n.1, 2014.

SÁNCHEZ HERNÁNDEZ, C.: "Garantía hipotecaria, mercado y crisis económica: bases para su reformulación”, en Revista de Derecho Patrimonial, n.35, septiembre-diciembre 2014.

SÁNCHEZ RUIZ DE VALDIVIA, I.: “Introducción. Alternativas ante el drama social y el problema legal que plantean los desahucios y las ejecuciones hipotecarias en los consumidores. También en las empresas (PYMES, emprendedores y trabajadores autónomos)", en Desahucios y ejecuciones hipotecarias (un drama social y un problema legal), dir. por SÁNCHEZ RUIZ DE VALDIVIA, I./OLMEDO CARDENETE, M., Valencia, Tirant lo Blanch, 2014.

SEMPERE NAVARRO, A.V. (Director): La solución extrajudicial de los conflictos laborales (Los sistemas autonómicos de solución de conflictos en España), 
coord. por FERNÁNDEZ-COSTALES MUÑIZ, J./GARCÍA RODRÍGUEZ, B./MIÑARRO YANINI, M., León, Eolas Ediciones, 2014.

SENÉS MOTILLA, C.: “La reforma de la ejecución ordinaria e hipotecaria”, en La protección del deudor hipotecario Aproximación a la Ley de Medidas para reforzar la protección a los deudores hipotecarios, reestructuración de deuda y alquiler social, dir. por NÚÑEZ IGLESIAS, Á. y coord. por ESCARTÍN IPIÉNS, J.A./MARTOS CALABRÚS, M.A., Granada, Comares, 2014.

SERRANO GARCÍA, I.: "Soluciones legales en materia de desahucios en España", en Revista Jurídica del Notariado, $n^{\circ} .86-87$, abril/junio - julio/septiembre 2013.

SOSA WAGNER, F./FUERTES, M.: Bancarrota del Estado y Europea como contexto, Madrid-Barcelona-Buenos Aires, Marcials Pons, 2011.

STROIE, I.R.: "Alternativas a la resolución de conflictos en materia de consumo: la Directiva 2013/11/UE del Parlamento Europeo y del Consejo y el Reglamento (UE) No 524/2013 del Parlamento Europeo y del Consejo, de 21 de mayo de 2013", en Revista CESCO de Derecho de Consumo, $\mathrm{n}^{\circ} .7$, 2013 (http://www.revista.uclm.es/index.php/cesco).

- “¿Es viable un modelo de mediación de consumo autónomo desde el punto de vista de las materias que puedan ser objeto de mediación?", en Revista CESCO de Derecho de Consumo, n.14, 2015 (http://www.revista.uclm.es/ index.php/cesco).

STÜRNER, M.: "ADR and adjudication by State Courts: competitors or complements?", en STÜRNER, M./GASCÓN INCHAUSTI, F./CAPONI, E. (editores), The role od consumer ADR in the Administration of justice. New Trends in Access to Justice under EU Directive 2013/11, München, Sellier European Law Publishers, 2015.

TAMAYO HAYA, S.: "La mediación aplicada al sobreendeudamiento del consumidor", en Mediación, arbitraje y resolución extrajudicial de conflictos en el siglo XXI, coord. por GARCÍA VILLALUENGA, L./TOMILLO URBINA, J./VÁZQUEZ DE CASTRO, E./FERNÁNDEZ CANALES, C., Vol.1 (Mediación), Madrid, Reus, 2010.

TASENDE CALVO, J.J.: "El arbitraje de consumo: Objeto y exclusiones: El arbitraje de arrendamientos urbanos y el de transporte", en Actualidad Civil, $n^{\circ} .4$, 1997.

TORRES ESCÁMEZ, S.: "Protección del deudor hipotecario y principios jurídicos", en La protección del deudor hipotecario. Aproximación a la Ley de Medidas para reforzar la protección a los deudores hipotecarios, reestructuración de deuda y alquiler social, dir. por NÚÑEZ IGLESIAS, Á. y coord. por ESCARTÍN IPIENS, J.A./MARTOS CALABRÚS, Ma.A., Granada, Comares, 2014.

TORTELLA, G./NÚÑEZ, C.E.: Para comprender la crisis, Madrid, Gadir, 2009. 
TRUCHERO CUEVAS, J.: “Cuando el incentivo es no pactar”, en La Ley, n.8507, 25 marzo 2015.

VALBUENA GONZÁLEZ, F.: “La Directiva europea sobre resolución alternativa de litigios (ADR) en materia de consumo", en Justicia: Revista de derecho procesal, $\mathrm{n}^{\circ} .2$, diciembre 2014.

VALERO FERNÁNDEZ-REYES, Á.: “Aspectos sociológicos, jurídicos y registrales del Real Decreto-Ley 6/2012, de medidas urgentes de protección de deudores hipotecarios sin recursos", en Revista Crítica de Derecho Inmobiliario, $\mathrm{n}^{\circ} .753,2013$.

VALIÑO, V.: "Ejecuciones hipotecarias y derecho a la vivienda: estrategias jurídicas frente a la insolvencia familiar", Observatorio DESC (Derechos Económicos, Sociales y Culturales), septiembre 2009 (www.descweb.org).

VALL RIUS, A.: “La intermediación en problemáticas hipotecarias”, en Revista Digital MM, $\mathrm{n}^{\circ} .2$, diciembre 2012 (www.mundomediacion.es).

VÁZQUEZ DE CASTRO, E.: “La negociación y mediación hipotecaria”, en Anuario de mediación y solución de conflictos, $\mathrm{n}^{\circ} .1,2013$.

- “La solución negociada ante la ejecución hipotecaria”, en Revista Crítica de Derecho Inmobiliario, $\mathrm{n}^{\circ} .740,2013$.

VIGIL DE QUIÑONES OTERO, D.: “EI Registro, la hipoteca, los consumidores y la autorregulación de los acreedores", en Códigos de Conducta y préstamos hipotecarios, coord. por DÍAZ RUIZ, E., Madrid, Dykinson, 2013.

VIGUER SOLER, P.L.: "Análisis crítico del RDL 1/2015 sobre "Segunda oportunidad": expectativas, luces y sombras", en La Ley, $n^{\circ} .8592,29$ julio 2015.

YÚFERA SALES, P., Arrendamientos urbanos. Análisis práctico de la normativa arrendaticia aplicable, sistematizada por conceptos, $3^{a}$ ed., Barcelona, Bosch, 2006.

ZUNZUNEGUI, F.: "Sobreendeudamiento y prácticas hipotecarias de las entidades bancarias", en Revista de Derecho Bancario y Bursátil, n.129, enero-marzo 2013.

ZURITA MARTÍN, I.: “La suspensión de los lanzamientos sobre viviendas de colectivos especialmente vulnerables (A propósito de los presupuestos señalados en la Ley $1 / 2013$, de 13 de mayo)", en Actualidad Civil, n.7/8, julio-agosto 2013.

- Préstamo hipotecario, ejecución y dación en pago, Madrid, La Ley, 2014.

- "Reflexiones sobre la ampliación del umbral de exclusión y el ámbito de aplicación del Código de Buenas Prácticas por medio del Real Decreto-Ley 1/2015, de 27 de febrero, de mecanismo de segunda oportunidad, reducción de carga financiera y otras medidas de orden social", en La Ley, $n^{\circ} .8520,16$ abril 2015. 